\title{
NIST Manufacturing Process Planning and CAME Workshop
}

\section{Workshop Proceedings}

Marriott Hotel, Gaithersburg, MD

June 10-11, 1996

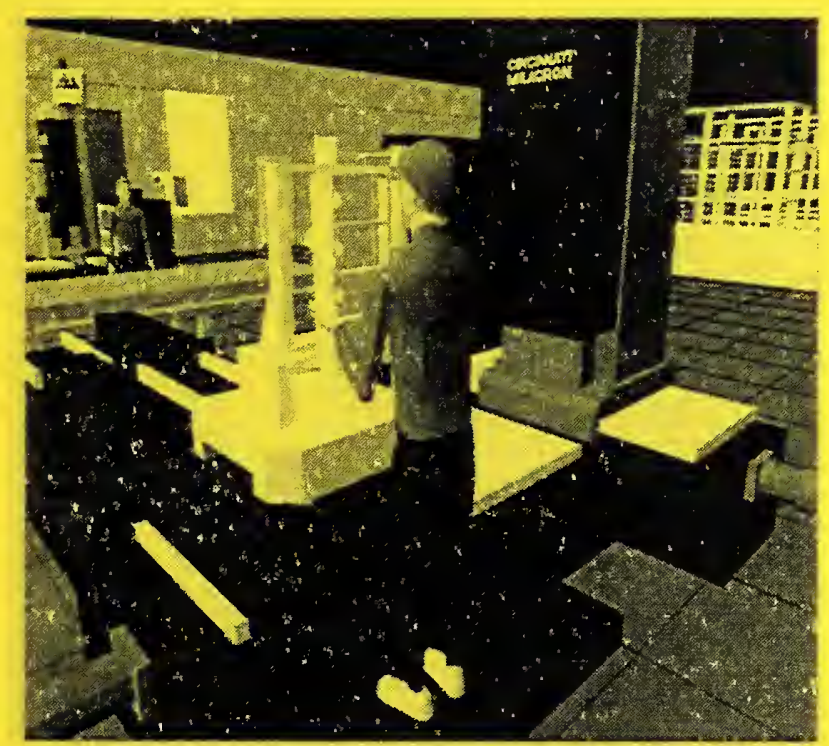

\section{Mike Smith \\ Swee Leong \\ William Regli \\ Sponsored by the}
U.S. Department of Commerce Technology Administration National Institute of Standards and Technology
Manufacturing Systems Integration Division Gaithersburg, MD 20899
and

U.S. Navy Manufacturing Technology Program

\section{NIST}

\section{$Q C$ \\ 100 \\ .056}

N0.6142 



\section{NIST Manufacturing Process Planning and CAME Workshop}

\section{Workshop Proceedings}

Marriott Hotel, Gaithersburg, MD

June 10-11, 1996

\section{Mike Smith \\ Swee Leong \\ William Regli}

Sponsored by the

U.S. Department of Commerce Technology Administration National Institute of Standards and Technology

Manufacturing Systems Integration Division Gaithersburg, MD 20899

and

U.S. Navy Manufacturing Technology Program

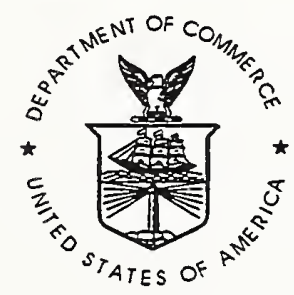

U.S. DEPARTMENT OF COMMERCE William M. Daley, Secretary

TECHNOLOGY ADMINISTRATION Gary R. Bachula, Acting Under Secretary for Technology

NATIONAL INSTITUTE OF STANDARDS AND TECHNOLOGY

Raymond G. Kammer, Director 


\section{Table of Contents}

WORKSHOP OVERVIEW AND OBJECTIVES

PROGRAM BACKGROUND AND UPDATE

CAME Forum Update and Program Overview .................................................................... 8

Manufacturing Process Planning Update ........................................................................... 8

KEYNOTE ADDRESSES

Process Planning: Capturing the Imagination, Dr. David Bourne,

Robotics Institute, Carnegie-Mellon University............................................................... 10

Business and Operations Requirements, Mr. Pete Buca, Parker

Hannifin Corporation

MechanicalSpace, Mr. Peter Brooks, Director, Mechanical Products,

Bentley Systems, Inc.

BREAKOUT SESSION I -- TECHNOLOGY FUTURES (GENERAL)

Session Overview ................................................................................................................ 12

Research Perspective ........................................................................................................... 12

Developer/Vendor Perspective ...................................................................................... 14

Manufacturer Perspective ............................................................................................... 15

Breakout Session Summary ........................................................................................ 17

BREAKOUT SESSION II -- TECHNOLOGY FUTURES (SPECIFIC) __ 18

Session Overview .......................................................................................................... 18

Technology and Business Culture ................................................................................. 18

Manufacturing Domains ..................................................................................................... 19

Information Technology Paradigms............................................................................ 21

Breakout Session Summary ...................................................................................... 22

BREAKOUT SESSION III -- TECHNOLOGY FORUM__ 23

Session Overview ............................................................................................................... 23

Architecture and Tool Integration ................................................................................ 26

Business Needs and Experience/Research Exchange ............................................... 27

Dynamic Process Planning ................................................................................... 28

Feature Recognition and Representation ..................................................................... 28 
Integrated Planning ......................................................................................................... 31

Multi-Domain Process Planning .................................................................................. 32

Product/Process Data ................................................................................................... 34

Breakout Session Summary ............................................................................................. 35

BREAKOUT SESSION IV -- ROLES AND ACTIONS __ 36

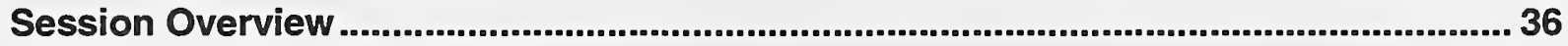

Users/Manufacturers Roles and Actions ......................................................................... 36

Government/Standards Agencies Roles and Actions.................................................. 37

Developer/Nendor Roles and Actions ............................................................................ 39

Research Community Roles and Actions ........................................................................ 40

Breakout Session Summary .................................................................................................... 41

WORKSHOP SUMMARY AND NEXT STEPS

APPENDICES _ 43

Appendix A. Workshop Participants

Appendix B. Workshop Agenda

Appendix C. Program Updates and Keynote Presentations 


\section{ACRONYMS}

Al

AP

API

BPR

CAD

CAM

CAME

CAPP

CMM

CORBA

Cyc

DCE

DFX

ECO

EDM

ERP

IDL

IGES

ISO

IT

KA

MES

MRP

NC

NIST

NSF

OLE

OMG

O०

PC

PDM
Artificial Intelligence

Application Protocol

Application Program Interfaces

Business Process Re-engineering

Computer-Aided Design

Computer-Aided Manufacturing

Computer-Aided Manufacturing Engineering

Computer-Aided Process Planning

Coordinate Measurement Machine

Common Object Request Broker Architecture

A knowledge-based product by CyCorp

Distributed Computing Environment

Design for Manufacturability, Design for Manufacturing and assembly, etc.

Engineering Change Order

Engineering Data Management

Enterprise Resource Planning

Interface Definition Language

Initial Graphics Exchange Specification

International Organization for Standardization

Information Technology

Knowledge Acquisition

Manufacturing Execution Systems

Materials Requirement Planning

Numerical Control

National Institute of Standard and Technology

National Science Foundation

Object Linking and Embedding

Object Management Group

Object-Oriented

Personal Computer

Product Data Management 


$\begin{array}{ll}\text { PP } & \text { Process Planning } \\ \text { ROI } & \text { Return of Investment } \\ \text { R\&D } & \text { Research \& Development } \\ \text { STEP } & \text { Standard for the Exchange of Product Model Data } \\ \text { VLSI } & \text { Very Large Scale Integrated Circuit } \\ \text { VRML } & \text { Virtual Reality Modeling Language } \\ \text { WWW } & \text { World Wide Web }\end{array}$




\section{WORKSHOP OVERVIEW AND OBJECTIVES}

The 1996 Process Planning Workshop and Computer-Aided Manufacturing Engineering (CAME) Forum convened June 10-11, 1996, in Gaithersburg, Maryland. The workshop was sponsored by the National Institute of Standards and Technology (NIST), the U.S. Navy Manufacturing Technology Program and the Defense Advanced Research Projects Agency (DARPA). Invitations to participate in the workshop were extended to participants in earlier workshops held as part of the Process Planning Workshop Series and previous technical meetings of the CAME Forum.

Eighty individuals from the research, software development/vendor, manufacturing, and government communities attended the workshop. Of non-government attendees, about half were from the academic research sector, about $30 \%$ were manufacturers, and the balance was application software developers/vendors. A list of workshop participants is provided in Appendix A. Abstracts submitted in advance of the workshop by many invitees helped shape the workshop objectives and content. Participants' interests covered a range of process planning and manufacturing engineering topics including

- Features, Al/Process Planning, NC machining

- Systems integration and deployment

- Process modeling and representation

- CAPP as a critical-path tool in software supporting concurrent/collaborative engineering

Workshop objectives were formulated to address the expressed interest of participants and the specific goals of NIST's Manufacturing Engineering Laboratory. The objectives of this workshop were to

- Identify research and development issues and directions

- Determine research critical points

$\Rightarrow$ Features/Feature Recognition

$\Rightarrow$ Integration standards and APIs

$\Rightarrow$ Interfaces to CAD, simulation, scheduling

$\Rightarrow$ Other topics as appropriate

- Provide a rich technical interchange with colleagues and collaborators across perspectives

- Collect opinions and find common needs

- Update the status of ongoing programs

The two-day workshop was designed to promote interaction and sharing among workshop participants. The workshop design sought to enable and facilitate collaboration between industrial counterparts; between industry and academia; and among industry, academia, and NIST participants. The design provided opportunities to report the status of NIST and other research and development (R\&D) programs and to learn the R\&D needs of the manufacturing community. It provided an opportunity to inform funding agencies about program needs and program progress. Finally, the workshop was designed to be self-documenting to the greatest extent possible so that 
workshop proceedings could be prepared and disseminated using materials developed by workshop participants.

Figure 1 illustrates typical relationships among groups represented at the workshop. These groups' interests and perspectives are summarized briefly below:

- Users (manufacturers) need process planning and integration tools that make them competitive. They are the markets for developers' and vendors' products and services and they create the need for new technologies and innovation.

- Developers/vendors respond to market demands by creating new process planning and manufacturing integration tools and services that make manufacturers more competitive. They build on ideas and proven concepts provided by the research community.

- Researchers find new ways to look at manufacturing issues and opportunities and discover, invent, and demonstrate concepts and technologies that can improve manufacturing competitiveness.

- Government Agencies, Industry Associations, and Standards Organizations seek to establish relationships, incentives, mechanisms, and standards that help researchers, developers, and users converge on high value-added tools and technologies that enhance manufacturing competitiveness.

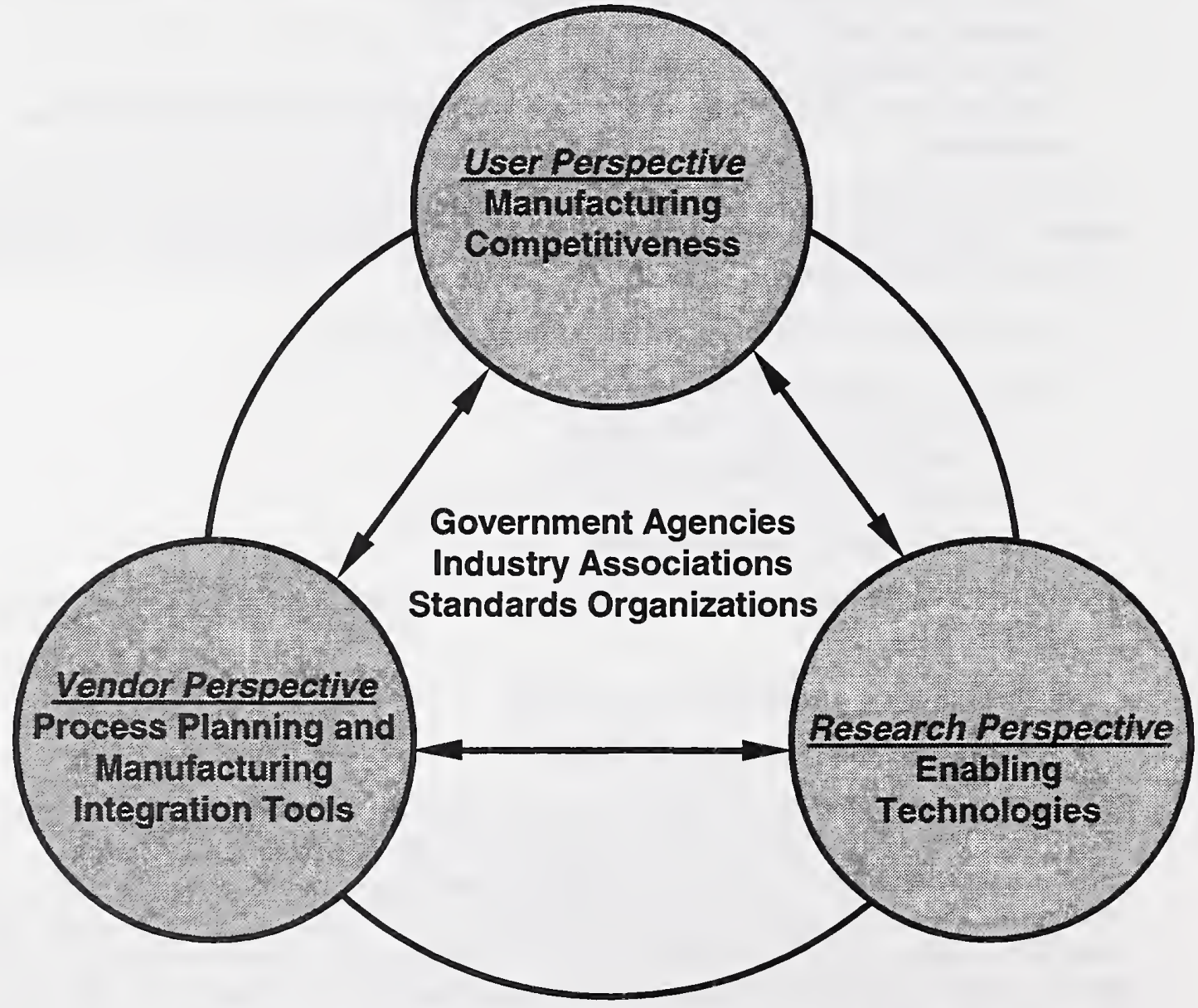

Figure 1. Relationships Among Manufacturing Stakeholders 
The workshop was organized around a series of four breakout and report back sessions. The sessions were interleaved with keynote addresses by distinguished speakers from the research and development and application software vendor communities. Appendix B shows the detailed agenda for the workshop. Table 1 describes the four breakout session topics, the composition of the breakout groups, and the desired outcome of each breakout session.

Table 1. Overview of Workshop Breakout Sessions

\begin{tabular}{|c|l|l|l|}
\hline $\begin{array}{c}\text { Breakout } \\
\text { Session }\end{array}$ & \multicolumn{1}{|c|}{ Description } & \multicolumn{1}{|c|}{ Groups } \\
\hline $\begin{array}{c}\text { I I } \\
\text { 10:15am, } \\
\text { 11:45am }\end{array}$ & $\begin{array}{l}\text { Discovery session to identify } \\
\text { and assess technologies, } \\
\text { tools, and needs. }\end{array}$ & $\begin{array}{l}\text { Organized around } \\
\text { research, development, } \\
\text { and user perspectives }\end{array}$ & $\begin{array}{l}\text { Assessments of } \\
\text { identified technologies, } \\
\text { tools, and needs }\end{array}$ \\
\hline $\begin{array}{c}\text { II } \\
\text { Monday, } \\
\text { 2:00pm - } \\
\text { 3:30pm }\end{array}$ & $\begin{array}{l}\text { Probes into specific areas } \\
\text { likely to influence the course } \\
\text { of technology development } \\
\text { and application }\end{array}$ & Self-selection & $\begin{array}{l}\text { Insights into strategic } \\
\text { directions for IT, } \\
\text { business culture, and } \\
\text { application domains }\end{array}$ \\
\hline $\begin{array}{c}\text { III } \\
\text { Tuesday, } \\
\text { 9:45am - } \\
\text { 10:45am }\end{array}$ & $\begin{array}{l}\text { Explore specific technologies } \\
\text { of interest to workshop } \\
\text { participants }\end{array}$ & $\begin{array}{l}\text { As Assigned and self- } \\
\text { selection }\end{array}$ & $\begin{array}{l}\text { Interchange of R\&D } \\
\text { and applications status } \\
\text { of current and } \\
\text { emerging technologies }\end{array}$ \\
\hline $\begin{array}{c}\text { IV } \\
\text { 1:00pm - } \\
\text { 2:30pm }\end{array}$ & $\begin{array}{l}\text { Identify and recommend roles } \\
\text { and activities for each } \\
\text { segment of the manufacturing } \\
\text { stakeholder community }\end{array}$ & $\begin{array}{l}\text { As Assigned -- mixed } \\
\text { groups of researchers, } \\
\text { developers, users, and } \\
\text { agencies/organizations }\end{array}$ & $\begin{array}{l}\text { Recommended roles } \\
\text { and near to mid-term } \\
\text { activities }\end{array}$ \\
\hline
\end{tabular}

As stated in the breakout sessions, the data presented in the table was provided in its raw form. Because of the number of concurrent activities, the editors were unable to participate in all of the data collection sessions. Corrections and expansions were made wherever possible. 


\section{PROGRAM BACKGROUND AND UPDATE}

This meeting brought together the Process Planning and the Computer-Aided Manufacturing Engineering groups interested in common manufacturing-related issues. Many attendees were participants in one or more of three previous workshops in a series of Process Planning Workshops. Two of the previous process planning workshops sought to collect ideas and establish consensus within the academic process planning community. The third workshop brought together software/system vendors and manufacturers/contractors to discuss the functionality of process planning systems, the integration of process planning systems into the larger manufacturing system environment, and the obstacles to and opportunities for the introduction of new technologies for process planning. Proceedings of the most recent Process Planning Workshop are documented in a NIST report. ${ }^{1}$

Other workshop attendees are members of the CAME Forum. CAME Forum members include university-based researchers, software developers and vendors, manufacturing engineers, and manufacturing managers. The CAME Forum met twice previous to this workshop to examine issues relating to manufacturing engineering data generation, data validation, and to evaluate progress in development of a manufacturing engineering toolkit (METK). Proceedings of the most recent CAME Forum Technical Meeting are documented in a NIST report. ${ }^{2}$

\section{CAME Forum Update and Program Overview}

Chuck Mclean provided an overview of the Computer-Aided Manufacturing Engineering (CAME) program. The CAME program is placing an emphasis on providing an integrated Manufacturing Engineering Tool Kit (METK). The objectives of the METK project are to (1) define interfaces and integrate software tools for planning machined parts and, (2) develop and test a methodology for validating manufacturing engineering data using commercial off-the-shelf software. He described the system's software modules, the capabilities and contributors of the tool kit project. He announced the CAME consortium that would address the engineering tool integration and manufacturing data validation issues. Mr. McLean's briefing slides are provided in Appendix C.

\section{Manufacturing Process Planning Update}

Dr. Steven Ray provided a summary of the three prior Process Planning workshops, and briefly discussed the structure and rationale for the current workshop. He described ongoing research as part of the NIST Manufacturing Process Planning Testbed project, and identified the suite of commercial software systems available at NIST for use by staff, visiting researchers, and collaborators. Specific NIST activities include the

\footnotetext{
1 Steven R. Ray, editor, Proceedings of the 1993 Industrial Process Planning Workshop, Report Number NISTIR 5284, U.S. Department of Commerce, Technology Administration, National Institute of Standards and Technology, Manufacturing Engineering Laboratory, Factory Automation Systems Division, June, 1993.

2 Michael C. Smith and Swee Leong, editors, Computer-Aided Manufacturing Engineering Forum, Second Technical Meeting Proceedings, Report Number NISTIR 5846, U.S. Department of Commerce, Technology Administration, National Institute of Standards and Technology, Manufacturing Systems Integration Division, August, 1995.
} 
creation of an Internet repository of manufactured part designs

(http://www.parts.nist.gov/parts), an online bibliographic citation database

(http://www.nist.gov/msid/projs/pptb/homepage.html), standardization activities related to ISO 10303-213 ("Process plans for NC machining"), and an effort to define a general process specification language (http://www.nist.gov/psl). Dr. Rays briefing slides are provided in Appendix $\mathrm{C}$. 


\section{KEYNOTE ADDRESSES}

\section{Process Planning: Capturing the Imagination, Dr. David Bourne, Robotics Institute, Carnegie-Mellon University}

Dr. Bourne, representing the research community, discussed the Automated Bending Expert $(A B E)$ developed at the Robotics Institute. Using the theme "Every Part is a Boundary Part," Dr. Bourne begin with a discussion of the general process planning approach and described the problems associated with process planning for a complex sheet metal component and operations planning for a single machine. He discussed elements of sheet metal bending including robots, tools, backage contacts, and loading/unloading fixtures, and the machine operations sequence. The generative process planning approach embodied in $A B E$ derives from first principles, such as developing unambiguous language for specifying a bending operation and identifying a near optimal plan for completing multiple bending operations (e.g., based on feasibility, handling requirements, and time.)

Dr. Bourne identified several of the research challenges associated with sheet metal fabrication process planning. These include

- recognizing the "right" features that define part geometry

- understanding the interactions among features

- sharing features between process domains (e.g., tooling features with grasping)

- developing machine independent process planning approaches

- accommodating tolerances in process planning

Dr. Bourne's approach is to integrate automated planning of part production on machines with engineering planning (via design software) so that the part can be redesigned if necessary and the production plan can be optimized. Dr. Bourne illustrated how information sharing between production planning and engineering design can reduce process/production planning time and increase the competitiveness of sheet metal fabrication.

Dr. Bourne's briefing charts are provided in Appendix C.

\section{Business and Operations Requirements, Mr. Pete Buca, Parker Hannifin Corporation}

Mr. Buca, a major user of engineering and manufacturing process planning design tools, described the organization, business units, products, types of industries that the Parker Hannifin Corporation serves. He described business relationships between Hannifin and its primary aerospace customers and its first, second and third tier subcontractors.

Parker Hannifin is a first tier supplier to the aerospace industries. They interact with their customers electronically. Designs and drawings are received from customers in a proprietary feature-based electronic format. Designs are prepared in-house and 
drawings are given to the contractors in multiple CAD formats depending on the needs of their customers and its subcontractors.

Parker Hannifin uses ProEngineer as their primary CAD platform and supports file transfer and data sharing with their customers and subcontractors. Mr. Buca

emphasized the need for STEP but also cited many of the issues with STEP as it is still in development. He noted that STEP is in its infancy and cannot, at present, be used in a production mode.

\section{Mechanical Space, Mr. Peter Brooks, Director, Mechanical Products, Bentley Systems, Inc.}

Mr. Brooks provided the perspective of process planning software vendors. Bentley Systems, working with other engineering software vendors, developed a "single engineering model" approach - "Mechanical Space" - that integrates MicroStation Modeler, COSMOS/M, ADAMS, ESPRIT/MS and other products. This integrated suite of engineering and process planning software products delivers productivity-enhancing and quality-improving desktop solutions for mechanical designers, drafters, engineers, and manufacturing professionals.

This suite of tools provides 3D assembly, solid, surface, and wireframe modeling; functional modeling (stress, dynamics, thermal, and fluid mechanics); motion and mechanism analysis; automated geometric dimensioning and tolerancing; sheet metal fabrication planning; metal deformation and fabrication process planning; and data interfaces with CAM databases. Mechanical Space has over 2000 application program interfaces (APIS). It supports current and emerging data exchange standards; and, it operates across multiple platforms and operating systems.

Mechanical Space and related engineering design and process planning tools are described in greater detail in Mr. Brooks briefing charts provided in Appendix C. 


\section{BREAKOUT SESSION I -- TECHNOLOGY FUTURES (GENERAL)}

\section{Session Overview}

The objective of the first breakout session was to identify and assess technologies, tools, and needs. Participants joined one of three breakout groups based on their individual perspectives - researcher, developer/vendor, user/manufacturer. Each breakout group considered a specific triggering question designed to elicit general issue relevant to that perspective. Each breakout group used a similar process of first identifying responses to the triggering question, organizing those responses into categories that served to identify trends and commonalties and to facilitate communicating results during the plenary session, and then providing an assessment of the technology in terms of technical maturity, market readiness, or competitive potential. Results of these three breakout groups are presented and discussed below.

\section{Research Perspective}

Participants from the research community addressed the following triggering question:

What are the new technologies that will facilitate manufacturing integration and process planning?

Results of the research breakout group are shown in Table 2. Discussion included product/process representation, information architecture, use of the WWW, algorithms for optimizing multiple design and manufacturing criteria, data management/ warehousing, computational efficiency, and human/computer interfaces. Each technology was discussed in relation to specific manufacturing needs and research challenges as well as an assessment of the current status of the enabling technology. 
Table 2. Breakout Session I Report -- Research Breakout Group

\begin{tabular}{|c|c|c|c|}
\hline $\begin{array}{c}\text { Enabling } \\
\text { Technology }\end{array}$ & $\begin{array}{l}\text { Manufacturing } \\
\text { Need Addressed }\end{array}$ & $\begin{array}{c}\text { Technical Hurdles/ Research } \\
\text { Challenges }\end{array}$ & Assessment \\
\hline \multirow[t]{2}{*}{$\begin{array}{l}\text { World Wide } \\
\text { Web }\end{array}$} & $\begin{array}{l}\text { Supply Chain } \\
\text { Management }\end{array}$ & $\begin{array}{l}\text { Vendor/Distributor/ Manufacturer } \\
\text { Relations } \\
\text { Methods of Electronic Accounting } \\
\text { Load Management, ease of changing } \\
\text { suppliers (for example) based on current } \\
\text { status } \\
\text { Copyright analogy - bring existing } \\
\text { methods up to speed }\end{array}$ & $\begin{array}{l}\text { Basic research/ } \\
\text { proof of principle }\end{array}$ \\
\hline & $\begin{array}{l}\text { Distributed Design/ } \\
\text { Manufacturing } \\
\text { (Contract tendering) }\end{array}$ & $\begin{array}{l}\text { Security: How much data to provide? } \\
\text { Information abstraction } \\
\text { (Assume electronic security covered by } \\
\text { people who know more than us) }\end{array}$ & Company Policy \\
\hline $\begin{array}{l}\text { Human } \\
\text { Computer } \\
\text { Interaction }\end{array}$ & $\begin{array}{l}\text { Usability, Visual } \\
\text { understanding, } \\
\text { familiarity }\end{array}$ & $\begin{array}{l}\text { Which level of detail to represent, and } \\
\text { when } \\
\text { Task balance, sometimes the computer } \\
\text { shouldn't be doing everything } \\
\text { Context specific representations based } \\
\text { on current detail of model, required detail }\end{array}$ & $\begin{array}{l}\text { Basic research } \\
\text { exists, just } \\
\text { applied to our } \\
\text { domain (cognitive } \\
\text { theory) }\end{array}$ \\
\hline $\begin{array}{l}\text { Parallel and } \\
\text { distributed } \\
\text { computing }\end{array}$ & $\begin{array}{l}\text { Addresses accessing } \\
\text { distributed information } \\
\text { in real time }\end{array}$ & $\begin{array}{l}\text { Algorithm parallelization, network } \\
\text { awareness }\end{array}$ & $\begin{array}{l}\text { Basic research in } \\
\text { reformulation as a } \\
\text { distributed } \\
\text { problem. }\end{array}$ \\
\hline $\begin{array}{l}\text { Architectural } \\
\text { Description } \\
\text { Language }\end{array}$ & $\begin{array}{l}\text { Rapid development, } \\
\text { flexible to allow } \\
\text { change }\end{array}$ & Making it scaleable, extensible & Proof of principle \\
\hline $\begin{array}{l}\text { Communication } \\
\text { among } \\
\text { architectural } \\
\text { elements }\end{array}$ & $\begin{array}{l}\text { Integration (internal } \\
\text { and external) }\end{array}$ & Standardization, extensibility, inertia & Demonstration \\
\hline $\begin{array}{l}\text { Data } \\
\text { Warehousing }\end{array}$ & $\begin{array}{l}\text { Storage and retrieval } \\
\text { Integration with legacy } \\
\text { data }\end{array}$ & $\begin{array}{l}\text { Culture, work required; extracting data/ } \\
\text { Information from humans. }\end{array}$ & $\begin{array}{l}\text { Demonstration, } \\
\text { some } \\
\text { development }\end{array}$ \\
\hline $\begin{array}{l}\text { Reference } \\
\text { architecture, } \\
\text { virtual machine }\end{array}$ & $\begin{array}{l}\text { Platform/ hardware } \\
\text { independence }\end{array}$ & $\begin{array}{l}\text { Process models, understanding process } \\
\text { buy-in, sharing without stifling } \\
\text { competition }\end{array}$ & $\begin{array}{l}\text { Basic research, } \\
\text { demonstration }\end{array}$ \\
\hline $\begin{array}{l}\text { Encryption, } \\
\text { firewalls }\end{array}$ & $\begin{array}{l}\text { Security of distributed } \\
\text { systems }\end{array}$ & Ease of use & Demonstration \\
\hline$\frac{\text { Near }}{\text { optimization }}$ & $\begin{array}{l}\text { Cost reduction, } \\
\text { product quality, } \\
\text { throughput }\end{array}$ & $\begin{array}{l}\text { New algorithms } \\
\text { New representations } \\
\text { Heterogeneous optimization criteria } \\
\text { Multi-disciplinary objectives }\end{array}$ & Basic research \\
\hline Feedback & $\begin{array}{l}\text { Integration - CAD/ } \\
\text { CAPP/ CAM }\end{array}$ & Data representation, capture, delivery & Application \\
\hline Agents & Dynamic planning & Human-computer interface & Basic research \\
\hline
\end{tabular}

\footnotetext{
- Assessment: nature of research required, e.g., basic research to discover principles or relationships, proof of principle to confirm hypothesized relationships or functionality, technology demonstration to show functionality, capability, effectiveness, etc.
} 


\begin{tabular}{|c|c|c|c|}
\hline $\begin{array}{l}\text { Enabling } \\
\text { Technology }\end{array}$ & $\begin{array}{l}\text { Manufacturing } \\
\text { Need Addressed }\end{array}$ & $\begin{array}{l}\text { Technical Hurdles/ Research } \\
\text { Challenges }\end{array}$ & Assessment \\
\hline $\begin{array}{l}\text { Simulation and } \\
\text { analysis }\end{array}$ & $\begin{array}{l}\text { Cost analysis } \\
\text { Validation } \\
\text { Evaluation }\end{array}$ & $\begin{array}{l}\text { Representation } \\
\text { Process models } \\
\text { Cost models } \\
\text { Interaction - multi-domain }\end{array}$ & $\begin{array}{l}\text { Basic research } \\
\text { (next } 5 \text { years - } \\
\text { electronic } \\
\text { commerce) }\end{array}$ \\
\hline $\begin{array}{l}\text { Representation/ } \\
\text { standards }\end{array}$ & $\begin{array}{l}\text { Communications } \\
\text { Center of integration }\end{array}$ & $\begin{array}{l}\text { Complexity of capturing intent diversity } \\
\text { Simplicity } \\
\text { Process independent representation } \\
\text { Linkage of product and process } \\
\text { information }\end{array}$ & Basic research \\
\hline $\begin{array}{l}\text { Features } \\
\text { (intent, product } \\
\text { description, } \\
\text { translation) } \\
\end{array}$ & $\begin{array}{l}\text { Translation of design } \\
\text { representation into } \\
\text { manufacturing action }\end{array}$ & $\begin{array}{l}\text { Inclusion of tolerance information } \\
\text { Non-machining feature }\end{array}$ & $\begin{array}{l}\text { Basic research or } \\
\text { proof of concept, } \\
\text { depending on } \\
\text { domain }\end{array}$ \\
\hline Data mining & $\begin{array}{l}\text { Extending the usability } \\
\text { of information }\end{array}$ & Mapping various data & Basic research \\
\hline All of above & $\begin{array}{l}\text { Integration into a } \\
\text { single system }\end{array}$ & $\begin{array}{l}\text { Combining the technical advances } \\
\text { Scaling, demonstrate in a real system } \\
\text { Funding! }\end{array}$ & Demonstration \\
\hline
\end{tabular}

\section{Developer/Vendor Perspective}

The developer/vendor breakout group considered the following triggering question:

What are the next generation tools to support manufacturing integration and process planning?

The developer/vendor breakout group used Figure 2 as the catalyst for discussion of their triggering question. This figure shows the area where software tools can assist manufacturers in achieving a more competitive design-to-production environment. Table 3 shows the result of their discussion. Participants listed specific process planning and integration tools, noted the manufacturing needs addressed, and then identified the enabling technologies required to make the tools possible. Finally, participants assessed the current status of the tools they identified.

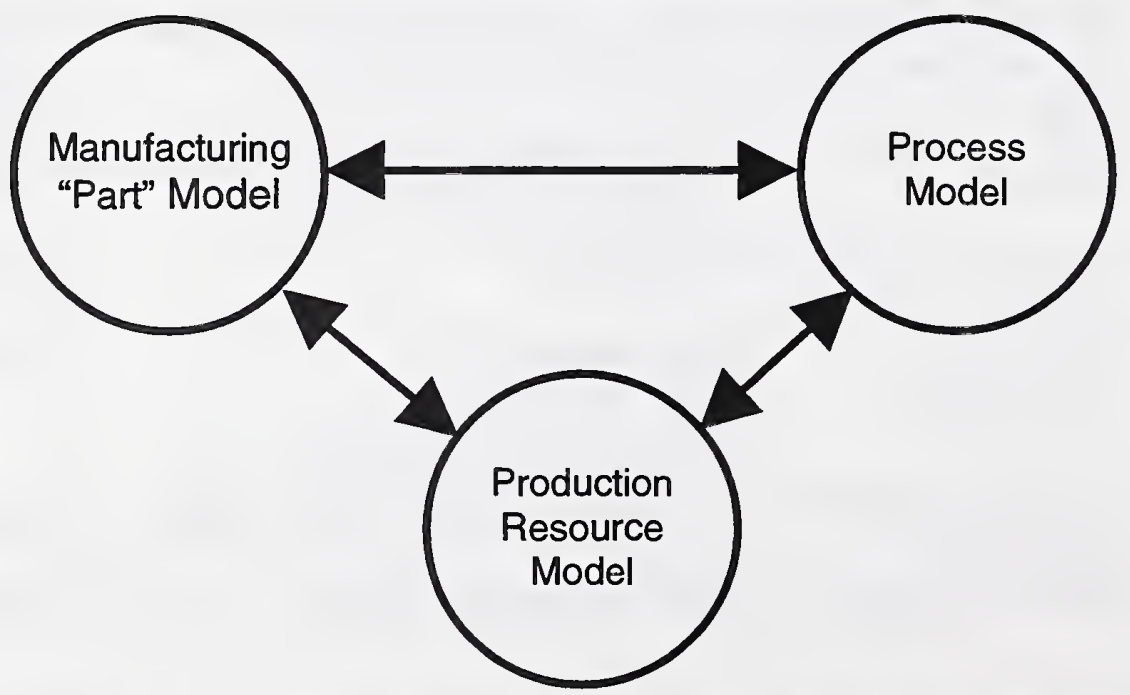

Figure 2. Process Planning and Product Data Modeling Relationships 
Table 3. Breakout Session I Report -- Developer/Nendor Breakout Group

\begin{tabular}{|c|c|c|c|}
\hline $\begin{array}{l}\text { Process Planning } \\
\text { \& Integration } \\
\text { Tools } \\
\end{array}$ & $\begin{array}{c}\text { Manufacturing Needs } \\
\text { Addressed }\end{array}$ & $\begin{array}{c}\text { Enabling Technologies (e.g., } \\
\text { standards, Software, } \\
\text { integration, architecture) }\end{array}$ & Assessment \\
\hline Inter-/Intranet & Delivery mechanism & WWW, JAVA, VRML & Pilots \\
\hline $\begin{array}{l}\text { CAD Model } \\
\text { Standards }\end{array}$ & $\begin{array}{l}\text { CAD Integration } \\
\text { Manufacturing Model } \\
\text { Data Representation } \\
\text { - Features (not just } \\
\text { geometry) } \\
\text { - Geometric } \\
\text { Dimensioning and } \\
\text { Tolerances } \\
\text { - Workpiece } \\
\end{array}$ & STEP and Children & Inadequate \\
\hline Interfaces & Integration & $\begin{array}{l}\text { OLE/CORBA } \\
\text { "Plug \& play" environment } \\
\text { Access to other vendors' data/ } \\
\text { visualization } \\
\text { Associativity }\end{array}$ & $\begin{array}{l}\text { Not defined } \\
\text { Proprietary }\end{array}$ \\
\hline Features & $\begin{array}{l}\text { Data between systems } \\
\text { Association of methods } \\
\text { with geometry }\end{array}$ & $\begin{array}{l}\text { Need multiple levels } \\
\text { Not just physical } \\
\text { Parametric } \\
\text { STEP (we hope) }\end{array}$ & "It ain't there" \\
\hline $\begin{array}{l}\text { Plan representation } \\
\text { and editing }\end{array}$ & $\begin{array}{l}\text { Capture corporate } \\
\text { knowledge base } \\
\text { Perform proprietary } \\
\text { retrieval }\end{array}$ & $\begin{array}{l}\text { Proprietary knowledge bases } \\
\text { Structured Query Language }\end{array}$ & $\begin{array}{l}\text { In-house } \\
\text { solutions } \\
\text { No general } \\
\text { standards } \\
\text { Niche markets }\end{array}$ \\
\hline
\end{tabular}

\section{Manufacturer Perspective}

Participants from the user/manufacturer perspective considered the following question:

What are the critical information technology needs and challenges that affect manufacturing competitiveness?

Table 4 shows results of the user/manufacturer discussion of this triggering question. Note that this breakout group addressed technology requirements from the perspective of their effect on manufacturing competitiveness.

\footnotetext{
"Assessment: status of the tool in terms such as availability (e.g., now, 1, 3, 5 years out), development status (e.g., prototype, testing, COTS), and market potential in terms of value and potential demand
} 
Table 4. Breakout Session I Report -- User Breakout Group

\begin{tabular}{|c|c|c|c|}
\hline Competitive Needs & $\begin{array}{l}\text { Key IT Tools and } \\
\text { Technologies }\end{array}$ & $\begin{array}{c}\text { Business Case } \\
\text { Elements }\end{array}$ & Assessment' \\
\hline $\begin{array}{l}\text { Required definition \& } \\
\text { management } \\
\text { - Design rules of current } \\
\text { manufacturing capacity and } \\
\text { other "ilities" } \\
\text { - Data exchange (product } \\
\text { process capability) } \\
\text { - Data management } \\
\text { - Capture process knowledge }\end{array}$ & $\begin{array}{l}\text { Data base software } \\
\text { Artificial Intelligence } \\
\text { Intelligent interoperability of } \\
\text { component based } \\
\text { manufacturing software }\end{array}$ & $\begin{array}{l}\text { Speed } \\
\text { Quality } \\
\text { Cost Flexibility }\end{array}$ & \\
\hline $\begin{array}{l}\text { Interoperability - global plug \& } \\
\text { play }\end{array}$ & $\begin{array}{l}\text { Standards } \\
\text { User friendly interface }\end{array}$ & $\begin{array}{l}\text { Reduced } \\
\text { integration cost }\end{array}$ & \\
\hline $\begin{array}{l}\text { Analytical support tools } \\
\text { - new product development } \\
\text { - focused on cost, cycle time, } \\
\text { market driven, user friendly, } \\
\text { plug \& play }\end{array}$ & $\begin{array}{l}\text { 1. manufacturing simulation } \\
\text { systems } \\
\text { 2. Knowledge-based } \\
\text { systems } \\
\text { 3. DFX systems } \\
\text { 4. PDM systems } \\
\text { 5. Feature-based CAD } \\
\text { 6. Cost analysis } \\
\text { 7. Life cycle analysis } \\
\text { 8. Business process tools } \\
\text { 9. Concurrent engineering - } \\
\text { virtual enterprises }\end{array}$ & $\begin{array}{l}\text { Reduce } \\
\text { development cycle } \\
\text { time } \\
\text { Reduce scrap, } \\
\text { rework } \\
\text { Lower costs } \\
\text { Mass } \\
\text { customization } \\
\text { Minimize ECOs } \\
\text { Increase } \\
\text { production rates }\end{array}$ & $\begin{array}{l}\text { Readiness/ } \\
\text { Affordable } \\
\text { 1. low/low } \\
\text { 2. low/low } \\
\text { 3. low/low } \\
\text { 4. med-high/med } \\
\text { 5. med/low } \\
\text { 6. high/low } \\
\text { 7. low/low } \\
\text { 8. high/high } \\
\text { 9. high/low }\end{array}$ \\
\hline $\begin{array}{l}\text { Data Access and Exchange } \\
\text { - to filter large amount of data to } \\
\text { useful information } \\
\text { - global information } \\
\text { dissemination for } \\
\text { manufacturing support } \\
\text { - interoperability between } \\
\text { commercial tools (plug \& play) } \\
\text { - security on manufacturing } \\
\text { data } \\
\text { - multimedia delivery of product } \\
\text { process information } \\
\text { - data exchange standards } \\
\end{array}$ & $\begin{array}{l}\text { Intelligent, flexible filtering } \\
\text { systems }\end{array}$ & $\begin{array}{l}\text { Improve quality } \\
\text { Reduce time } \\
\text { Reduce cost }\end{array}$ & \\
\hline
\end{tabular}

\footnotetext{
" Assessment: Indicate potential return on investment (payoff) and market readiness (e.g., willingness of users to invest) for tools that meet competitive needs.
} 


\begin{tabular}{|l|l|l|l|}
\hline \multicolumn{1}{|c|}{ Competitive Needs } & \multicolumn{1}{|c|}{$\begin{array}{c}\text { Key IT Tools and } \\
\text { Technologies }\end{array}$} & $\begin{array}{l}\text { Business Case } \\
\text { Elements }\end{array}$ & Assessment* \\
\hline $\begin{array}{l}\text { Data and Knowledge Mgmt. } \\
\text { - quick, easy, standard methods } \\
\text { to capture and maintain } \\
\text { process planning knowledge } \\
\text { data integration of } \\
\text { manufacturing applications } \\
\text { knowledge-based support } \\
\text { tools }\end{array}$ & $\begin{array}{l}\text { Data base management } \\
\text { systems } \\
\text { Product Data Management } \\
\text { systems }\end{array}$ & $\begin{array}{l}\text { Improve quality } \\
\text { Reduce time } \\
\text { Reduce cost }\end{array}$ & \\
\hline
\end{tabular}

\section{Breakout Session Summary}

The result of breakout session I is the combined perspectives of users (manufacturers), developer/vendors, and researchers that is obtained by looking for the commonalities across Tables 2-4. The common thread that runs through all three tables is the need for product and process data representations that can be easily exchanged across applications and platforms and the analytical tools to act on these data to support manufacturing decisions leading to higher quality, lower cost, greater throughput, and reduced cycle times. The "bottom line" is that the enabling technologies must satisfy the business needs of the manufacturing community to produce a more competitive manufacturing enterprise. 


\section{BREAKOUT SESSION II -- TECHNOLOGY FUTURES (SPECIFIC)}

\section{Session Overview}

During breakout session II, participants considered three specific areas likely to influence the course of manufacturing process planning technology development and application. Participants were asked to choose one of three breakout groups to discuss one of the three following questions:

Business Culture: How will manufacturing integration and process planning technologies affect the next business "culture" (and vice-versa)?

Manufacturing Domains: What manufacturing domains beyond machining are attractive targets for integration and process planning technologies?

IT Paradigm: What will become the dominant information technology paradigm for manufacturing engineering and process planning?

The intent of these three questions was to elicit insights into the strategic directions for information technology as it applies to manufacturing. Importantly, participants (especially those considering the business "culture" issue) were asked to think about how business factors will influence technology development (e.g., supply chain integration). Each breakout group was asked to suggest strategic directions, provide a rationale or justification for that direction, and then assess the effect of that direction on manufacturing.

\section{Technology and Business Culture}

Participants in the "business culture" breakout group considered the challenges facing manufacturers, discussed the business factors that will affect technology development and selection, and then speculated about future directions in manufacturing that will likely affect process planning technology development. Results of their discussions are summarized below.

\section{Challenges facing manufacturers:}

1. Knowledge capture and transfer with high data security

2. High reliability authentication to ensure appropriate access to data

3. Effects of advanced manufacturing technology on the manufacturing workforce (skill base, virtual workforce, etc.)

\section{Business factors that will affect technology development and application:}

1. Globalization of both competition and markets

2. Outsourcing of selected manufacturing functions, especially to offshore sources

3. Increased use of fixed price contracts that add cost pressures

4. World class quality expectations

5. Zero inventory to achieve cost reductions but require maximum agility 

6. Consolidation around core competencies
7. Intensive supply chain management
8. Virtual organizations
9. Strategic management

\section{What is next for manufacturers and manufacturing?}

1. Advanced hybrid techniques of production (mechatronics)

2. Niche specialists to augment available technology and capacity

3. Design-to-order manufacturing (e.g., VLSI)

4. "Rent-a-planner" to replace or augment in-house manufacturing planning capability (process planning and other manufacturing integration as a service)

5. Technology is a commodity; information is a commodity (e.g., easy access to both purchase decisions based on price and delivery)

\section{Manufacturing Domains}

Participants who chose to consider which manufacturing domains might be attractive targets for integration and process planning technologies spent time discussing reasons for expanding to other domains, defining manufacturing domains, and developing an "attractiveness metric" for use in choosing target domains. This group concluded that domains should be selected based on opportunities to save time and/or money and to improve quality and/or safety.

The group discussed several strategic trends likely to cause process planning and manufacturing integration tools to expand beyond traditional metal removal domains. Table 5 summarizes these directions and the rationale for their selection. Note that Table 5 does not address specific domains but identifies trends in manufacturing that are likely to lead to new application domains.

Table 5. Breakout Session II Report Out - Manufacturing Domains

\begin{tabular}{|l|l|l|}
\hline \multicolumn{1}{|c|}{ Strategic Direction } & Rationale/Justification & Effect on Manufacturing \\
\hline \hline Planning for lot sizes of one & Customer demand & $\begin{array}{l}\text { High cost of line change and } \\
\text { material handling }\end{array}$ \\
\hline $\begin{array}{l}\text { Net shape or near net shape } \\
\text { castings }\end{array}$ & $\begin{array}{l}\text { Saves material, lower capital, leads } \\
\text { to standardization }\end{array}$ & $\begin{array}{l}\text { More volume out of same floor } \\
\text { space, lower cost }\end{array}$ \\
\hline $\begin{array}{l}\text { Look at integration of manufacturing } \\
\text { and design at front end of project }\end{array}$ & & \\
\hline
\end{tabular}


The group offered the following results of their discussion:

Domain possibilities by type operation:

1. Assembly

2. Tubing/wire harness

3. Welding

4. Sheet metal fabrication

5. Composites

6. Forming (casting, forging, injection molding, etc.)

Domain possibilities by industry type:

1. Apparel

2. Wood working

3. Chemical

4. Food products
7. Surface finishing (plating, heat treating, etc.)

8. Inspection

9. Workflow management

10. Packaging

11. Material handling

The "attractiveness metric" offered is

No. of parts made by technology Difficulty of automation
Research

funding

available for $=$ Attractiveness

automation automation

Results of the manufacturing domain discussion are summarized in Table 6 . Note that in Table 6 the group identified specific domains for consideration based on their understanding of manufacturing trends and the competitive environment.

Table 6. Breakout Session II Report Out -Manufacturing Domains

\begin{tabular}{|c|c|c|}
\hline Strategic Direction & Rationale/Justification & Effect on Manufacturing \\
\hline $\begin{array}{l}\text { 1. Assembly } \\
\text { 2. Layered Technology } \\
\text { 3. Forming (injection molding, } \\
\text { extrusion, forging, etc.) } \\
\text { 4. Bending - sheet metal }\end{array}$ & $\begin{array}{l}\text { pro: all very popular processes; } \\
\text { many dollar saved by automation } \\
\text { con: difficult to integrate when } \\
\text { manufacturing process is not } \\
\text { automated }\end{array}$ & $\begin{array}{l}\text { Make custom manufacturing } \\
\text { feasible } \\
\text { improve performance } \\
\text { Reduce cost } \\
\text { Reduce production time } \\
\text { Increase quality }\end{array}$ \\
\hline
\end{tabular}

The group raised several questions that they did not address during this session: How should the role of process planning be expanded to include

- design feedback?

- multi-level process planning?

- multi-domain process planning?

- supply and resource constraints?

- fused variant and generative process planning? 


\section{Information Technology Paradigms}

The IT paradigm discussion group delineated a number of emerging technologies that will affect process planning tools and then developed a framework for surfacing issues and approaches that might lead to breakthroughs in manufacturing process planning. Table 7 shows the technologies they considered and why they felt these technologies will be important.

Table 7. Breakout Session II Report Out - IT Paradigms

\begin{tabular}{|l|l|}
\hline \multicolumn{1}{|c|}{ Strategic Direction } & \multicolumn{1}{|c|}{ Rationale/Justification } \\
\hline $\begin{array}{l}\text { Structured Query Language 3, intelligent filters, } \\
\text { advanced scripting languages }\end{array}$ & Compatible persistent storage \\
\hline CORBA, OLE, DCE & Common communication infrastructure \\
\hline Web technology, client/server & Geographic distribution \\
\hline JAVA, virtual machines & Platform heterogeneity \\
$\begin{array}{l}\text { Standards (e.g., feature lists) } \\
\text { Process models (e.g., SEMATECH framework) } \\
\text { Ontologies (e.g., Cyc knowledge base) }\end{array}$ & Shared semantics \\
\hline
\end{tabular}

This discussion group proposed a sequence of architectural steps that move from domain specific knowledge to an implementation strategy that cuts across domains. Figure 3 shows the product of this discussion, including areas where specific approaches are proposed and those where issues are raised that merit further investigation.

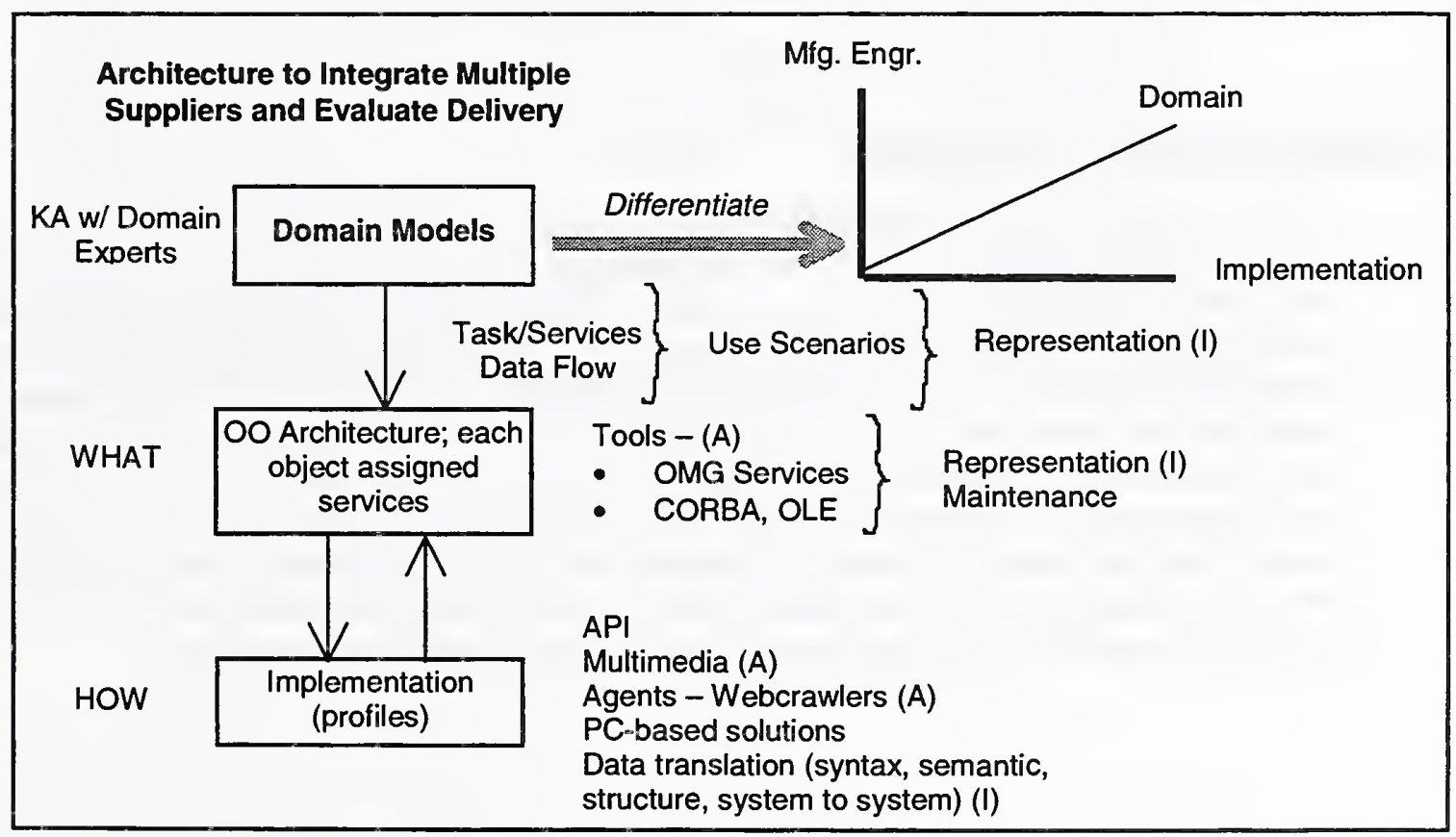

Figure 3. Approaches (A) and Issues (I) in developing the IT Paradigm 
The discussion group suggested a development timeframe for enabling technologies that are essential to implementing the next manufacturing process planning paradigm. Table 8 shows this development schedule in terms of five-year development periods. Note that several key technologies are believed to be five or more years into the future.

Table 8. Technology Development Timeframe

\begin{tabular}{|l|l|}
\hline \multicolumn{1}{|c|}{$\begin{array}{c}\text { Development } \\
\text { Timeframe }\end{array}$} & \multicolumn{1}{c|}{ Key Technologies } \\
\hline Now (0-5 years) & $\begin{array}{l}\text { APIs } \\
\text { Translators } \\
\text { Wrappers }\end{array}$ \\
\hline Near Term (5-10 years) & $\begin{array}{l}\text { OLE-CORBA } \\
\text { Infrastructure } \\
\text { Wrappers (IDL) } \\
\text { "Generic" Translators }\end{array}$ \\
\hline Future (10+ years) & $\begin{array}{l}\text { Standards } \\
\text { Objected-oriented } \\
\text { databases } \\
\text { JAVA++ } \\
\text { Shared ontologies }\end{array}$ \\
\hline
\end{tabular}

\section{Breakout Session Summary}

In summary, the second breakout session produced results that indicate a desire on the part of manufacturers to adopt more advanced process planning technologies but an indication that several critical technologies (including important data representation and exchange standards) are still several years off. The significant result of this breakout session is the indication that users and manufacturers understand the importance of emerging technologies to the new global, virtual, agile, and highly competitive business environment that is becoming more apparent to many manufacturers. The challenge to the IT community (research and vendors) is to work closely with manufacturers to ensure that the tools and standards that evolve in this environment are cost-effective from both manufacturing (i.e., they reduce cost and improve quality) and market (i.e., they improve agility, responsiveness, and market access) perspectives. 


\section{Session Overview}

Breakout session III was designed specifically to provide an opportunity for workshop participants to exchange ideas and information about their specific research and technology interests and accomplishments. A number of participants submitted abstracts in advance of the workshop indicating particular interests; others indicated their interests by submitting the technology survey card provided at the workshop. Table 9 lists the abstract topics submitted in advance of the workshop and the individuals who submitted them. Table 10 lists the topics submitted at the workshop. Note that topics submitted at the workshop were classified into similar categories to help in forming discussion groups for the third breakout session.

Table 9. Research Topics Submitted with Pre-Workshop Abstracts

\begin{tabular}{|l|l|}
\hline \multicolumn{1}{|c|}{ Research Topic } & \multicolumn{1}{c|}{ Submitted By } \\
\hline $\begin{array}{l}\text { Alternative process plans and incremental process } \\
\text { planning }\end{array}$ & Dusan Sormaz \\
\hline Automated feature recognition & Bob Tuttle \\
\hline Capturing feature interdependencies & Don Needham \\
\hline Facility design and production scheduling and control & J. MacGregor Smith \\
\hline Feature extraction and process planning & Caroline Hayes \\
\hline Featured-based product representation methods & Gordon Little \\
\hline Maintainable and extendible feature recognizer & Daniel Gaines \\
\hline Multiple domain process planning systems & Keith Hummel \\
\hline Process planning and BPR & $\begin{array}{l}\text { Bill Hlavacek, Steve } \\
\text { Haberman }\end{array}$ \\
\hline Process planning for parallel machines & Derek Yip-Hoi \\
\hline Quick response manufacturing & Yuan-Shin Lee \\
\hline Rapid tendering and manufacture of small lots & Kenneth Dalgarno \\
\hline
\end{tabular}


Table 10. Technology Topics Suggested by Workshop Participants

\begin{tabular}{|c|c|}
\hline Category & Technology Topic \\
\hline Architecture & System architecture (specifically 00 , agent-based) \\
\hline Business Needs & $\begin{array}{l}\text { Identify the potential payback/ROI for the implementation of } \\
\text { selected integration technologies or planning systems -- this } \\
\text { information would be useful for justifying programs to potential } \\
\text { sponsors, vendors, users, etc. }\end{array}$ \\
\hline $\begin{array}{l}\text { Dynamic } \\
\text { Integration }\end{array}$ & $\begin{array}{l}\text { Integration of process planning with scheduling and other } \\
\text { activities (dynamic process planning) }\end{array}$ \\
\hline $\begin{array}{l}\text { Dynamic } \\
\text { Integration }\end{array}$ & Incremental process planning (dynamic) \\
\hline $\begin{array}{l}\text { Dynamic } \\
\text { Integration }\end{array}$ & Real-time dynamic planning \\
\hline Experience & $\begin{array}{l}\text { Establishment of a software base providing for experimentation or } \\
\text { demonstration of experimental PP systems (on WWW) }\end{array}$ \\
\hline Experience & $\begin{array}{l}\text { Estimating systems used with CAPP or as part of CAPP -- } \\
\text { commercial systems, in-house systems. State of the art and } \\
\text { success stories and failures }\end{array}$ \\
\hline Experience & Two key elements to PP -- routing logic and estimating \\
\hline Features & $\begin{array}{l}\text { Solid modeling/feature recognition/manufacturing } \\
\text { engineering/integration/associated software development }\end{array}$ \\
\hline Features & Feature recognition and process planning (machining) \\
\hline Features & Manufacturing features \\
\hline Features & $\begin{array}{l}\text { There has been a wall between feature recognition and process } \\
\text { planning. There must be research work for destroying the wall } \\
\text { and integrating manufacturing knowledge to feature recognition. }\end{array}$ \\
\hline Features & $\begin{array}{l}\text { Feature recognition, CAD-->CAM, software development, } \\
\text { geometric reasoning }\end{array}$ \\
\hline Features & Feature-based design versus feature recognition \\
\hline Features & $\begin{array}{l}\text { Feature recognition for real world part and integration of the } \\
\text { whole process planning }\end{array}$ \\
\hline Features & Process planning and feature extraction \\
\hline Features & Tolerance representation \\
\hline $\begin{array}{l}\text { Integrated } \\
\text { planning }\end{array}$ & Process plans for shop-floor control \\
\hline $\begin{array}{l}\text { Integrated } \\
\text { planning }\end{array}$ & Systems planning, design, and analysis \\
\hline $\begin{array}{l}\text { Integrated } \\
\text { planning }\end{array}$ & $\begin{array}{l}\text { Process planning, facility layout, simulation, scheduling, and } \\
\text { material handling design and analysis }\end{array}$ \\
\hline $\begin{array}{l}\text { Integrated } \\
\text { planning }\end{array}$ & $\begin{array}{l}\text { Improve manufacturing/product design relationships so } \\
\text { manufacturing will use product design data }\end{array}$ \\
\hline $\begin{array}{l}\text { Integrated } \\
\text { planning }\end{array}$ & $\begin{array}{l}\text { Change propagation: The "ripple" effect that happens because of } \\
\text { either an upstream design change or a downstream change due } \\
\text { to manufacturing, tooling, etc.; using various software products } \\
\text { for GAD, GAM, CAPP, etc. }\end{array}$ \\
\hline $\begin{array}{l}\text { Integrated } \\
\text { planning }\end{array}$ & $\begin{array}{l}\text { Integration of technologies to develop producibility and cost } \\
\text { predictors for design systems that also suggest appropriate }\end{array}$ \\
\hline
\end{tabular}




\begin{tabular}{|c|c|}
\hline Category & Technology Topic \\
\hline & design changes to reduce cost and improve producibility \\
\hline $\begin{array}{l}\text { Integrated } \\
\text { planning }\end{array}$ & Optimization in planning \\
\hline $\begin{array}{l}\text { integrated } \\
\text { planning }\end{array}$ & Product/process planning \\
\hline Multi-domain PP & $\begin{array}{l}\text { Methods/technologies for capturing and representing } \\
\text { manufacturing data/information/knowledge for a range of } \\
\text { manufacturing domains (not just machining). How to apply these } \\
\text { methods/technologies to design. How are these } \\
\text { methods/technologies adaptable to the manufacturing } \\
\text { environment }\end{array}$ \\
\hline Multi-domain PP & Process planning in distributed control structure \\
\hline Multi-domain PP & Process planning of assembly products \\
\hline Multi-domain PP & $\begin{array}{l}\text { Identification of common research problems across planning } \\
\text { domains. There are many common problems across various } \\
\text { process planning domains. Some problems such as precedence } \\
\text { constraints are "mofe" important in one domain (assembly) than } \\
\text { others. }\end{array}$ \\
\hline Multi-domain PP & Multi-domain process planning \\
\hline Product data & on - part, process, resource \\
\hline Product data & Usefulness of STEP \\
\hline Product data & Product data (STEP, IGES) \\
\hline Product data & pecification issues \\
\hline Product data & $\begin{array}{l}\text { What level of data should be managed by PDM? So that data } \\
\text { can be shared efficiently -- blob or discrete attributes? }\end{array}$ \\
\hline Product data & Resource modeling \\
\hline Product data & $\begin{array}{l}\text { Who owns CAPP data? MRP/ERP? EDM/PDM? } \\
\text { MES/Production? }\end{array}$ \\
\hline Product data & Graphical work instructions (i.e., non-textual job plans) \\
\hline Product data & Master model assembly \\
\hline $\begin{array}{l}\text { Research } \\
\text { Exchange }\end{array}$ & $\begin{array}{l}\text { How to improve the interactions between researchers and } \\
\text { industries }\end{array}$ \\
\hline $\begin{array}{l}\text { Research } \\
\text { Exchange }\end{array}$ & $\begin{array}{l}\text { What are the different API tools desired by user/other } \\
\text { developers/researchers from CAD/CAM systems? Discussion } \\
\text { could be directed to system integrators }\end{array}$ \\
\hline Tool Integration & $\begin{array}{l}\text { Exploiting more information in the CAD model for CAD/CAM } \\
\text { integration. What info is there? How to use? Can it be } \\
\text { standardized? (Design history, function intent, tolerance, others?) }\end{array}$ \\
\hline Tool Integration & CAD integration \\
\hline Tool Integration & Integration of different modules for CAPP \\
\hline Tool Integration & $\begin{array}{l}\text { Multi-supplier integration -- what is needed and how do user } \\
\text { companies make vendors comply? }\end{array}$ \\
\hline Tool Integration & Design feedback \\
\hline Tool Integration & Integration \\
\hline Tooling & Fixture and tool design \\
\hline Tooling & NC machining -- tool selection and management \\
\hline
\end{tabular}


After reviewing abstracts submitted in advance of the workshop as well as technology topics submitted during the workshop, seven separate discussion tracks were established and participants selected the tracks of greatest interest to them. The seven tracks are (session leaders' names are in parenthesis):

1. Architecture and tool integration (Suzanne Barber)

2. Business needs/experience/research exchange (Bill Hlavacek/Steve Haberman)

3. Dynamic process planning (Ezat Sanii)

4. Feature recognition and representation (Yong Se Kim)

5. Integrated planning (Caroline Hayes)

6. Multi-domain process planning (S. K. Gupta)

7. Product/process data (Rick Franzosa)

Each group discussed the technology and needs related to the assigned track, recorded major elements of the discussion, and made observations and drew conclusion about the status of the technology, emerging trends, and research needs. Discussion leaders provided results of the discussion either in chart form at the conclusion of the session or via electronic mail shortly after the workshop. Summary results of each of these technology breakout group sessions are provided below.

\section{Architecture and Tool Integration}

This breakout group considered the complex problem of developing architectural standards that could accommodate the variety of data flows and applications needed to support manufacturing process planning. Table 11 lists the architecture/integration topics discussed and some of the issues to be considered when addressing them.

Table 11. Breakout Session III Report out - Architecture/Integration

\begin{tabular}{|c|c|c|}
\hline Integration Options & Integration \& Translation & Observations/Conclusions \\
\hline \multirow{4}{*}{$\begin{array}{l}\text { Integration Options } \\
\text { - Define domain-specific and } \\
\text { application-driven abstract } \\
\text { interface (domain = assembly, } \\
\text { sheet-metal; application = } \\
\text { CAD, PP, costing) } \\
\text { - Tools that build interface } \\
\text { - Pay vendors } \\
\text { - Bottom-up: integrate the } \\
\text { world by integrating tool by } \\
\text { tool } \\
\text { What can be generalized by } \\
\text { the experience }\end{array}$} & \multirow{4}{*}{$\begin{array}{l}\text { Models to breaking barriers } \\
\text { "Unix" model } \\
\text { "Microsoft" model } \\
\text { "De facto" model } \\
\text { "De jour" model } \\
\text { Data interoperability vs. Data } \\
\text { privacy vs. Data exchange } \\
\text { Buying services vs. Buying tools } \\
\text { Application component services } \\
\text { across domains vs. Turn key } \\
\text { systems }\end{array}$} & \\
\hline & & High level architecture \\
\hline & & $\begin{array}{l}\text { Low level architecture based } \\
\text { on prototyping }\end{array}$ \\
\hline & & TIME $\longrightarrow$ \\
\hline
\end{tabular}


The Architecture/Integration group concluded that there are a number of integration options and alternatives, but a major factor in the successful application of integrated process planning technologies will be the ability of manufacturers to transition from a relatively disintegrated planning approach to one that brings together multiple perspectives to consider design, manufacturing, production, supplier/distribution logistics, and other enterprise functions concurrently.

\section{Business Needs and Experience/Research Exchange}

The business needs/experience/research exchange focused on issues such as return on investment, methods for sharing experience with process planning tools, and opportunities to improve interactions between manufacturers and the research community. Their findings are summarized in Table 12.

Table 12. Breakout Session III Report Out - Business/Research Exchange

\begin{tabular}{||l|l||}
\hline $\begin{array}{c}\text { Technology } \\
\text { Topic(s) }\end{array}$ & \multicolumn{1}{|c|}{ Major Points/lssues Discussed } \\
\hline $\begin{array}{l}\text { Business Case } \\
\text { for process } \\
\text { planning }\end{array}$ & $\begin{array}{l}\text { Need - what level: pen/paper, CAPP, Variant, Generative PP } \\
\text { Architecture (Business): centralized/decentralized, World Wide Web } \\
\text { Where does PP data go in you company? } \\
\text { Minimize the cost of legacy system maintenance } \\
\text { Reuse of data } \\
\text { Capture corporate process knowledge } \\
\text { Need tool to communicate process information to design community at time of design (tool } \\
\text { could be a person) } \\
\text { Insure process consistency/quality }\end{array}$ \\
\hline $\begin{array}{l}\text { Research/ } \\
\text { Industry } \\
\text { relationships }\end{array}$ & $\begin{array}{l}\text { Better definition of expectation at project level between research and industry; industry needs } \\
\text { quick return on investment } \\
\text { "Collaboratory" - send students into plants to improve industry/research relationships } \\
\text { Companies need to put up more research \$ for research (risk \$) } \\
\text { Include software suppliers as part of industry }\end{array}$ \\
\hline
\end{tabular}

This group discussed the business case for second generation CAPP and generative process planning and the cost and configuration of process planning systems, including the cost of obtaining or generating planning data. 


\section{Dynamic Process Planning}

The dynamic process planning breakout group discussed process planning approaches that have the flexibility to accommodate changes after the initial plan has been developed. Table 13 shows the topics discussed and the major discussion points and observations.

Table 13. Breakout Session III Report Out - Dynamic Process Planning

\begin{tabular}{||l|l|l||}
\hline \multicolumn{1}{|c|}{$\begin{array}{c}\text { Technology } \\
\text { Topic(s) }\end{array}$} & \multicolumn{1}{|c|}{ Major Points/lssues Discussed } & Observations/Conclusions \\
\hline $\begin{array}{l}\text { Dynamic PP vs. } \\
\text { Integrated PP }\end{array}$ & $\begin{array}{l}\text { Integration is an implementation issue } \\
\text { which will be accomplished when } \\
\text { dynamic requirements are satisfied }\end{array}$ & \\
\hline $\begin{array}{l}\text { Definition of } \\
\text { dynamic PP (DPP) }\end{array}$ & $\begin{array}{l}\text { A PP system that accommodates for } \\
\text { changes in design, scheduling } \\
\text { requirements, shop floor status, } \\
\text { technological requirements }\end{array}$ & $\begin{array}{l}\text { DPP is to be accomplished } \\
\text { incrementally and not by complete } \\
\text { replanning }\end{array}$ \\
\hline $\begin{array}{l}\text { Information } \\
\text { requirements for } \\
\text { DPP }\end{array}$ & $\begin{array}{l}\text { Status information } \\
\text { - Part } \\
\text { Resource availability (load) } \\
\text { Scheduling data } \\
\text { Design change information }\end{array}$ & $\begin{array}{l}\text { Design change specification should be } \\
\text { accommodated in product modeling }\end{array}$ \\
\hline $\begin{array}{l}\text { Architectural } \\
\text { requirements }\end{array}$ & $\begin{array}{l}\text { Needs process planning manager (to } \\
\text { keep track of changes and instigate } \\
\text { incremental, specific actions) } \\
\text { Open system - accommodate for } \\
\text { dynamic links to various other systems } \\
\text { Modular } \\
\text { Distributed computed }\end{array}$ & \\
\hline $\begin{array}{l}\text { Representation of } \\
\text { PP requirements }\end{array}$ & \begin{tabular}{l} 
Hierarchical representation \\
\hline
\end{tabular} \\
\hline
\end{tabular}

The dynamic process planning discussion concluded that DPP must be accommodated in the product/process model architecture and DPP should be implemented in a modular, incremental manner.

\section{Feature Recognition and Representation}

The feature recognition and representation group was comprised of one user, four developers, and eight researchers. Topics addressed during their discussions include:

- Industry Needs

- Practical Use

- Other Domains than Machining

- Mapping Issues from Design to Diverse Applications 


\section{Major discussion points on these topics are:}

- Industry Needs: A Case from Texas Instruments:

Solid Model to Manufacturing Features Translation needed. What is important is volume corresponding to the removal. As typical feature-based solid modelers (e.g.,Pro/E) features are irrelevant for manufacturing and are used for part modeling purpose, translation is necessary.

Not all the machining details are crucial, as their primary purpose is to provide machining cost estimate at design stage.

- Views on what is manufacturing feature -- discussed views were divided into two perspectives:

What is important in features is the ability to select "processes," thus manufacturing features should contain as much details on machining as possible.

As providing flexibility in manufacturing (machining methods) is important and typically machining details "are" filled in at later stages (e.g., NC people), shape characteristics suitable to infer machining information is important (as used in Texas Instrument).

\section{Other remarks are:}

- Process planning stage does not determine all; at NC stage the details are filled in.

- "Pocketing is more difficult than slot" as more details are to be filled in more flexible manner.

- Features are dependent of the planning (process sequence).

- Features can be general because many ways to make part.

- Flexibility is needed for high level process selection.

- There is no "design" feature which can associate such diverse design specific information as designers address diverse product concerns. Only a small portions of design decision are indicated in traditional drawings, however, much less is specified in electronic solid models.

\section{What improvement is needed for features? (How rich the information should be tied to features)?}

- Process sequence and fixture information should be tied with features.

- Machining starts with the given stock, the features should be dependent on it.

- If a stock is completely given, it is easier. But for high-level process selection, determining more effective starting workpiece for machining considering the number of parts to be produced would be more challenging.

- Intermediate workpiece (in-process workpiece) determination and its reflection in the features are necessary.

- Grouping of features based on final part shape into workpiece removal features considering rough cutting and finish cutting would be desirable. 
What should be the starting information for features?

- AP203-like geometry

- Tolerance, surface finish

- Workpiece (stock)

- Process information -- is it specifiable?

$\Rightarrow$ In Drawing, not all are specified, but only crucial information and overall general information specified.

- Current reality of the CAD/CAM Packages are far from this ideal cases.

- Should tackle current problems.

Why less feature work on other domains than machining?

- Logistics are more crucial in machining compared to other manufacturing processes.

- Thus, there are more pay-off in pursuing all the possibles in machining.

- More decomposable in machining process issues and associated cost than in other processes.

- Some processes (e.g. painting) have well-specified process plan which can be easily enhanced to a generic process specifications.

- But machining is not the case; all cases are different -- then what other applications need similar support as in machining?

$\Rightarrow$ Inspection (e.g. CMM)

$\Rightarrow$ Assembly - Logistics are crucial.

* What are the assembly features?

* How much of assembly information is provided/decided at design?

* Maybe more information is given at design stage.

* Need for assembly feature recognition - repair, redesign?

$\Rightarrow$ Die Machining 


\section{Integrated Planning}

The integrated planning discussion group considered problems associated with having multiple design and manufacturing process planning tools, with many unable to communicate directly with others without human intervention or re-entering data. This group discussed the problems of legacy design and process planning systems that are in widespread use but are not easily integrated with newer tools.

Results of this discussion are provided in Table 14.

Table 14. Breakout Session III Report Out - Integrated Planning

\begin{tabular}{|c|c|c|}
\hline $\begin{array}{l}\text { Technology } \\
\text { Topic(s) }\end{array}$ & Major Points/lssues Discussed & Observations/Conclusions \\
\hline $\begin{array}{l}\text { Paradigm } \\
\text { integrating: } \\
\text { design and } \\
\text { process } \\
\text { planning }\end{array}$ & $\begin{array}{l}\text { 3D design technology is used in companies } \\
\text { today (mostly new) } \\
\text { - Manufacturing technology/software is older, } \\
\text { often written in-house and can't use 3D data } \\
\text { directly } \\
\text { - Same is true of business process technology }\end{array}$ & $\begin{array}{l}\text { - Manual tie-ins done now } \\
\text { - Leed manufacturing systems } \\
\text { - Less urgent is the need for } \\
\text { capability and process models } \\
\text { ('98) } \\
1 \text { bill of material }\end{array}$ \\
\hline $\begin{array}{l}\text { Paperless } \\
\text { manufacturing }\end{array}$ & $\begin{array}{l}\text { - Now often spend lots of effort recreating } \\
\text { paper instructions for shop floor } \\
\text { - Big } \$ \text { investment to go "paperless" } \\
\text { - Big step forward to accomplishing integration } \\
\text { is "paperless" manufacturing }\end{array}$ & $\begin{array}{l}\text { Need data standards to } \\
\text { accomplish } \\
\text { technology available piecemeal } \\
\text { now }\end{array}$ \\
\hline $\begin{array}{l}\text { Machine tool } \\
\text { standards/ } \\
\text { simulation }\end{array}$ & $\begin{array}{l}\text { Want machine capabilities from maker in a } \\
\text { standard form (data standards) for process } \\
\text { planning users } \\
\text { - Someone internal to company must } \\
\text { continually tune this data to keep model } \\
\text { correct } \\
\text { - Tool makers (and software makers) oversell }\end{array}$ & $\begin{array}{l}\text { - Need now } \\
\text { - Helps produce resource } \\
\text { models }\end{array}$ \\
\hline Assembly & $\begin{array}{l}\text { Want to be able to quickly simulate assembly } \\
\text { - Tools exist but one person must use everyday } \\
\text { or skill is lost } \\
\text { - Human-computer interface issues abound }\end{array}$ & $\begin{array}{l}\text { Flexible scenarios - automated } \\
\text { - manual different line } \\
\text { configurations and robot types } \\
\text { - Fast - at the cost of some } \\
\text { accuracy }\end{array}$ \\
\hline
\end{tabular}




\section{Multi-Domain Process Planning}

The multi-domain process planning group investigated other domains where process planning tools and technology might have merit. Summary results of their discussion are provided in Table 15, followed by a more detailed account of their discussion.

Table 15. Breakout Session III Report Out - Multi-Domain Process Planning

\begin{tabular}{|c|c|c|}
\hline $\begin{array}{c}\text { Technology } \\
\text { Topic(s) }\end{array}$ & Major Points/lssues Discussed & Observations/Conclusions \\
\hline $\begin{array}{l}\text { Requirements } \\
\text { for multi- } \\
\text { domain } \\
\text { process } \\
\text { planning }\end{array}$ & $\begin{array}{l}\text { - Hierarchical planning } \\
\Rightarrow \text { factory } \\
\Rightarrow \text { shop } \\
\Rightarrow \text { workstation } \\
\text { Ability to handle multiple process types }\end{array}$ & $\begin{array}{l}\text { Multi-level is needed. Levels } \\
\text { may be different for different } \\
\text { processes } \\
\text { Interfaced systems need to } \\
\text { identify functionality in each } \\
\text { domain }\end{array}$ \\
\hline $\begin{array}{l}\text { Common } \\
\text { elements }\end{array}$ & $\begin{array}{l}\text { - Features taxonomy } \\
\text { - } \quad \text { Process capability taxonomy } \\
\text { - } \quad \text { Reature to process capability matching } \\
\text { - }\end{array}$ & $\begin{array}{l}\text { Information is quite different; } \\
\text { for example, solid modeling will } \\
\text { not be good for chemical } \\
\text { manufacturing } \\
\text { How to represent processes for } \\
\text { different domains? }\end{array}$ \\
\hline $\begin{array}{l}\text { Attractive } \\
\text { domains }\end{array}$ & $\begin{array}{l}\text { - } \text { - Wetal forming } \\
\text { - } \text { Layered manufacturing } \\
\text { - } \text { Composite manufacturing } \\
\text { - Apparel manufacturing } \\
\text { - Weiding/ioining }\end{array}$ & $\begin{array}{l}\text { - Very few systems } \\
\text { new systems and research are } \\
\text { needed }\end{array}$ \\
\hline $\begin{array}{l}\text { Adapting } \\
\text { design for } \\
\text { process }\end{array}$ & $\begin{array}{l}\text { Multi-level design } \\
\Rightarrow \text { process independent } \\
\Rightarrow \text { process specific }\end{array}$ & $\begin{array}{l}\text { Currently do not exist } \\
\text { - It is not entirely clear if this is } \\
\text { achievable }\end{array}$ \\
\hline Integration & $\begin{array}{l}\text { - Common architecture } \\
\text { - Common representation of plans }\end{array}$ & $\begin{array}{l}\text { - Currently does not exist } \\
\text { - Should be a major focus }\end{array}$ \\
\hline
\end{tabular}

\section{Multi-Domain Process Planning}

Most of the process planning research has centered around machined parts. A number of other manufacturing processes can also benefit from automated process planning systems. In this breakout session, we attempted to discuss some of the research issues that relate to multi-domain process planning systems. We mainly discussed the following four areas.

\section{Requirements for Multi-Domain Process Planning}

We need process planning systems that can work with processes other than machining. In many of these newer manufacturing domains it will be extremely important to first understand the desired functionality of process planning systems (i.e, what a process planning system is supposed to do?).

We will also need to have systems that can handle multiple process types. Many parts are created by a combination of processes. For example, some parts are cast first, then 
machined, and finally ground to create the required product. If we want create systems that can handle multiple process types, process planning systems for each process type will need to have common architecture and plan representation across multiple domains.

Process planning systems need to operate at many different levels of abstractions. We will need hierarchical systems. For example, in case of machined parts, this hierarchy will be factory level, shop level and workstation level. Depending upon the particular process, these levels might be different.

\section{What are other attractive process domains of interest?}

Popularity of several other processes, and advantages offered by automation make several other domains extremely attractive for automated process planning. Some of the attractive domains identified by our group are listed below:
- assembly
- wood working
- metal forming
- apparel industry

- sheet metal bending

- layered manufacturing

- composite manufacturing

- welding/joining

There exists a large body of research in assembly planning. But unfortunately, there seems to be very poor communication among assembly planning and machining process planning research communities.

\section{Common Elements}

A number of process planning steps (or components) are likely to be common across many of these domains. For example, in most domains we will need feature taxonomy, process taxonomy, and feature process mappings. We will also need models of manufacturing resources. In feature/process taxonomies, we should be able create common sharable structures, but the actual information may be radically different from one domain to the other. For example, solid models may be good representations for machined parts, but they may be quite inadequate for chemical mixing. Adequate representation will need to be carefully selected. Also the taxonomies should be flexible enough to allow a wide variety of manufacturing processes.

\section{Adapting design across processes}

Parts are usually designed with a process in mind. If the intended process changes (due to change in product demand or process innovation), one needs to modify the design to make sure that it can meet the capabilities of the new process. For example, sheet metal housings are quite different from injection molded housings. Is it possible to accomplish such a transition automatically? One way to achieve this will be to create designs at many different levels of abstractions. For example, we can create designs at two different levels. The first step will be to create a process independent design. The second step will be to create the process dependent design. Process independent designs will be common across many different process domains. We can create an automated system to create process dependent designs from process independent designs. It is not entirely clear whether or not such a translation can be accomplished automatically in the short term. 


\section{Product/Process Data}

The product/process data group dealt with issues surrounding common representations of product design and manufacturing data. Their discussion covered three major topics: product and process data integration; standards; and process modeling. Results of this discussion are summarized below.

\section{Product \& Process Data Integration}

\section{Major Points / Issues Discussed}

- Although ancillary systems grow in functionality and range, such systems as PDM, ERP and MES do not properly integrate at the CAPP crossroads. Typically they overlap, leading to additional problems for the process planner, not additional solutions.

- Multiple data types, and formats are the domain of the manufacturing engineer.

- System Constraints - Architectures are always changing

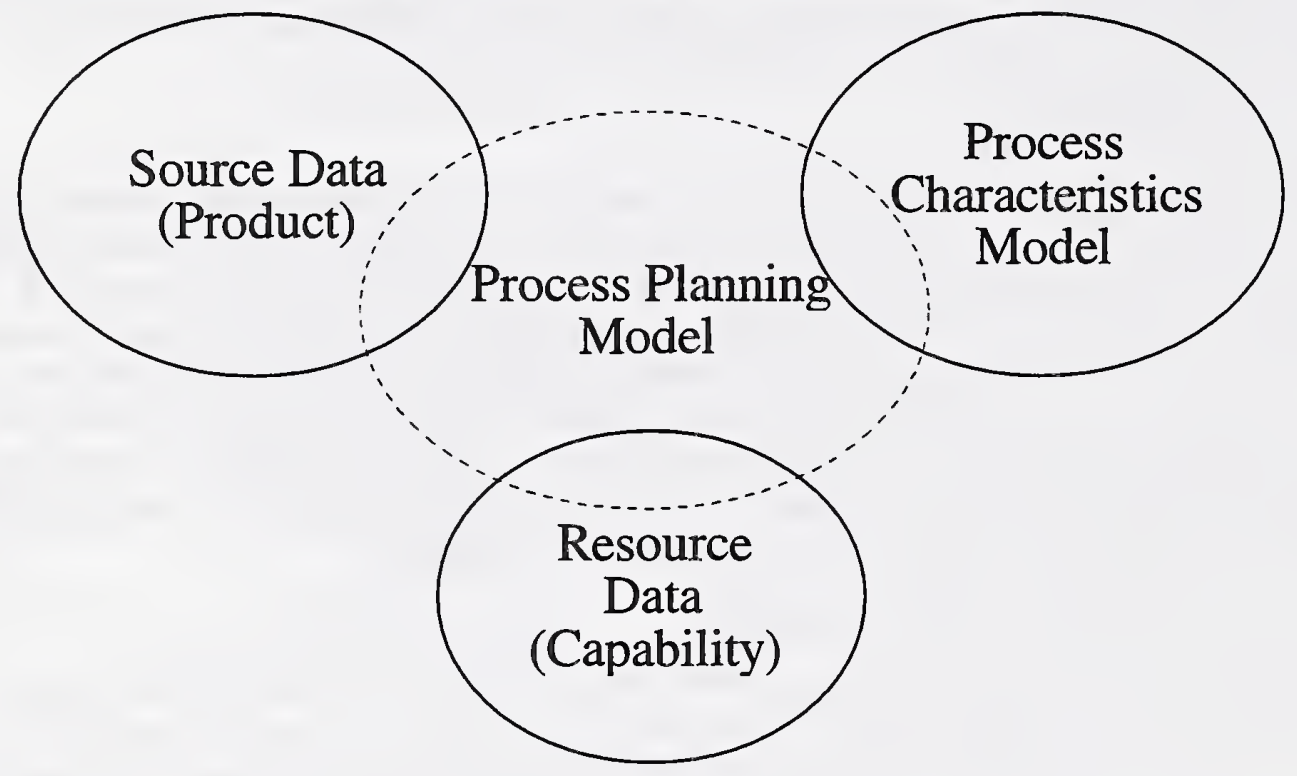

Figure 4. Process Planning Model Relationships

\section{Observations / Conclusions}

- Process planning is the glue between product, process and resource

- Need ability to manipulate, view, and deliver multiple data formats, types.

- Today's solutions are, at best, short term. Systems should be designed to reflect this, or allow incremental changes. 


\section{Standards}

\section{Major Points / Issues Discussed}

- STEP's inability to fully represent real world needs, and its tendency to try and cast standards in concrete.

- STEP /Express modeling rules sometimes conflict, or are not supported by IT tools/languages. For example, some valid constructs in EXPRESS produce 'bad' $\mathrm{C}++$.

- Lack of ability of standards and tool developers to provide timely, useful, cost effective deliverables is frustrating for manufacturers.

Observations / Conclusions

- Generic functions must become the basis of any process planning tool.

- Standards must be flexible, robust and amenable to change as we get smarter.

- Manufacturers can't wait and won't wait. They will just go out and do something in the absence of reliable, robust standards.

\section{Process Modeling}

\section{Major Points / Issues Discussed}

- There is a management perception that process planning systems are 'point solutions' and are not as critical (or even required) when compared with CAD/PDM, ERP, and MES systems.

- Easy to use tools can enable process planners to be more efficient.

- Automatic data movement/entry is important.

- Planner can then concentrate more on process improvement.

Observations / Conclusions

- Needs to be recognized in management that manufacturing engineering and process planning are major functions, on a par with the other applications.

- Major cost drivers are decided by manufacturing engineering.

- Business process understanding could be a remedy.

\section{Breakout Session Summary}

The technology breakout session succeeded in providing an opportunity for interested parties to exchange experiences, concerns, accomplishments, ideas, and research plans. Generally, several perspectives (developer/vendor, user/manufacturer, researcher, government agency) participated in each discussion group so that a broad view of the topic emerged. Because of their diverse nature, no attempt was made to find a common theme across all of the discussion topics but informal discussions among breakout group participants provided common ground for building future relationships. Participants expressed frustration in having limited time to explore these difficult manufacturing issues in detail but the topics discussed and the relationships formed 
provide an opportunity for individuals to pursue mutual interests in greater detail in other forums.

\section{BREAKOUT SESSION IV -- ROLES AND ACTIONS}

\section{Session Overview}

The final breakout session was design to encourage participants to think seriously about how each group represented at the workshop could best contribute toward resolving the difficult research, development, and implementation issues raised throughout the workshop. Breakout groups were formed around the four major perspectives represented at the workshop, namely manufacturers (users), developers/vendors, researchers, and government/standards agencies. Breakout groups were formed so that each perspective was represented in each of the breakout groups and each group was given a triggering question to stimulate discussion. The four breakout groups and triggering questions were:

Users/Manufacturers: What is the appropriate role of users/manufacturers in addressing manufacturing integration and process planning needs?

Gov't/Stds Organizations: What is the appropriate role of government and standards organizations in addressing manufacturing integration and process planning needs?

Development/Vendor. What is the appropriate role of developers/vendors in addressing manufacturing integration and process planning needs?

Research: What is the appropriate role of the research community in addressing manufacturing integration and process planning needs?

\section{Users/Manufacturers Roles and Actions}

The user/manufacturer role was characterized in terms of the following three major topics:

- Identify research issues

- Create generic interface specifications between CAD and process planning

- Identify function requirements and uses for process plans

The role of users/manufacturers in developing process planning tools was illustrated as shown in Figure 5. Users/manufacturers are in the best position to identify the practical problems associated with process planning and to determine if these problems are company-specific or application-specific or whether they have general applicability across a number of companies and/or application domains. General problems are best addressed in a broader context than a single company but do require the support, acceptance, and participation of the user/manufacturer community to ensure that they are formulated and developed properly. Company-specific problems can be classified according to the level of risk associated with solving the problems and applying the solutions. Low risk, easily-applied solutions can be addressed using in-house resources; higher risk problems require broader participation from the research and development community to provide access to the appropriate skill base and to spread risk across a larger number of participants. 


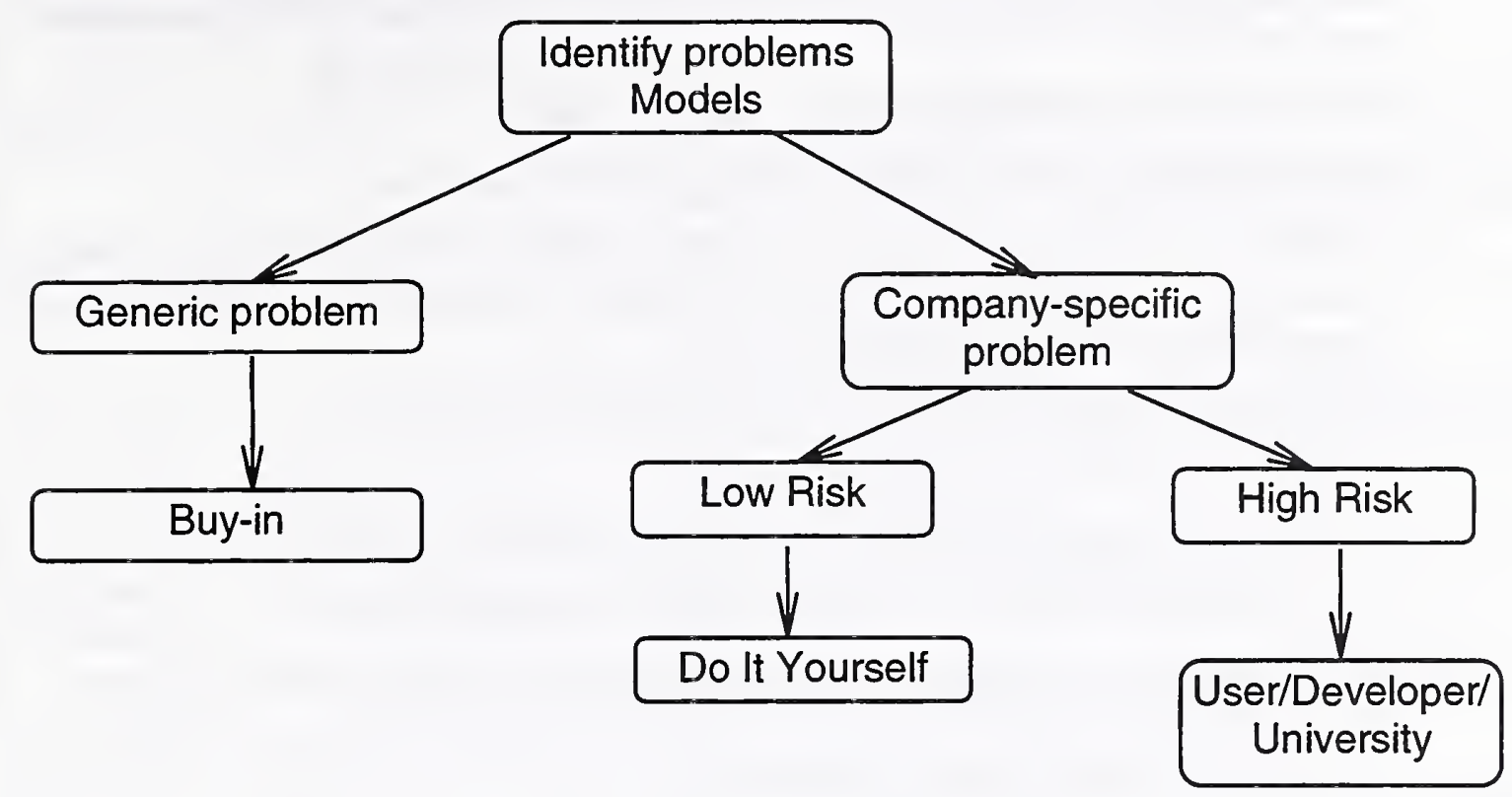

Figure 5. Decision Tree for User/Manufacturer Role in Process Planning Development Activities

In addition to identifying and addressing process planning problems, users/manufacturers fill several additional roles, including:

- Process knowledge base for designers

- Design by features

- Create feature-based process plan

- Process capability library

- Best practices framework

- Design guidelines

- Integration benchmarks

- Create incentives for manufacturers to work together

- Drive vendors to create cost effective solutions

\section{Government/Standards Agencies Roles and Actions}

The group considering the government/standards agency roles and actions agreed that these organizations cannot tell individuals or organizations what they must do except through incentives and other mechanisms that encourage compliance with widely accepted practices and standards. The group identified 21 topics where government/standards setting agencies can play a significant role, organized these topics into six major areas, and then proposed near term actions to help agencies fulfill these roles. The initial 21 topics are: 
1. Work with individual and university in developing vision of process planning and manufacturing integration direction for the future; identify standardization needs to accomplish this.

2. HELP define and articulate true manufacturing needs.

3. Create standard parts for testing functionality of various systems.

4. Organize a professional society for the advancement of process planning systems.

5. Provide for a repository and test bed functionality to assist in the development of advanced tools and technologies.

6. Encourage or spearhead standards for CAD data interchange.

7. Fund high risk-high payoff activities.

8. Manage maintenance of standards for various elements of CAPP.

9. Try to bring together major vendors for standards development.

10. Provide funding for a few key projects characterizing/identifying needs for main elements of CAPP.

11. Provide advice/analysis/review of research.

12. Jointly fund with industry high priority research projects.

13. Serve as "quarterback" between CAPP activities.

14. Create opportunities for interaction among various perspectives (e.g., workshops).

15. Encourage development of standards for resource characterization.

16. Prototype interface specification and models to fast track standards development.

17. Provide neutral facility to support and promote the use of common representations, frameworks, and architectures. (documentation, guidance, common looks and feels).

18. Provide support for small shops.

19. Bring together an accessible library of research developed tools for use by other researchers/vendors.

20. Serve as catalyst to discern industry needs with respect to education.

21. Facilitate interactions and understanding between research, development, and end users.

These twenty-one topics were organized into the six major areas shown in Table 16 and specific near-term actions were proposed as initial steps in each of the major areas.

Note that some of the twenty-one topics fall into more than one of the six major areas. 
Table 16. Government/Standards Agencies Roles and Actions

\begin{tabular}{|c|c|c|}
\hline $\begin{array}{l}\text { Suggested } \\
\text { Role }\end{array}$ & $\begin{array}{l}\text { Topics (from } \\
\text { above list) }\end{array}$ & Near Term Actions \\
\hline Funding & $(7,10,12)$ & $\begin{array}{l}\text { - Fund pre-ballot testing of developing standards } \\
\text { - Jointly fund (industry/government) intern programs for } \\
\text { university and government personnel working on shop } \\
\text { floor }\end{array}$ \\
\hline Interaction & $(9,4,14,20,21)$ & $\begin{array}{l}\text { - Identify next workshop topics } \\
\text { - Proceedings published within } 3 \text { months } \\
\text { - Put information on WWW with comment sheet }\end{array}$ \\
\hline Leadership & $\begin{array}{l}(1,2,4,6,11,13 \\
15,)\end{array}$ & $\begin{array}{l}\text { - Articulate and prioritize R\&D issues (e.g., maintain R\&D } \\
\text { hot list on WWW) } \\
\text { - Establish standards roadmap }\end{array}$ \\
\hline $\begin{array}{l}\text { Test Bed/ } \\
\text { Repository }\end{array}$ & $(3,5,8,17,19)$, & $\begin{array}{l}\text { Preliminary study to establish test bed and repository } \\
\text { requirements } \\
\text { - Identify industrial partners for participation in testing }\end{array}$ \\
\hline Standards & $(1,3,8,9,15,16)$ & $\begin{array}{l}\text { - Develop library of test cases } \\
\text { - } \quad \text { provide process plan preliminary format }\end{array}$ \\
\hline Extension & $(2,14,18,19)$, & $\begin{array}{l}\text { - Preliminary study to establish alternatives for providing } \\
\text { extension services }\end{array}$ \\
\hline
\end{tabular}

\section{Developer/Vendor Roles and Actions}

The developer/vendor discussion group chose to look at the roles of each of the groups because of the interactions among the various perspectives. The role of this group depends heavily on the other groups because it is neither the end user nor does it do the basic research needed to produce new tools and approaches. It is inherently market-driven and must use research products that respond to user/manufacturer demand.

The group developed a list of conceivable roles for the developer community, including those listed below. Note that some items are listed as questions, indicating lack of consensus on whether or not the developer/vendor should move in this direction:

- Develop a full-featured, feature-based, cost-effective process planning system.

- Learn the business of the manufacturers (the customers -- don't need bells and whistles).

- Focus on niche markets?

- Form broader partnerships?

- Build plug and play modules.

- Identify and build modular engines (see research suggestions below).

- Make products easy to use with Windows-based graphical user interfaces.

- Submit to STEP-compliance certification.

Table 17 shows this group's proposed roles and actions for other groups. 
Table 17. Developer/User Group's Proposed Roles and Actions for Other Perspectives

\begin{tabular}{|c|c|}
\hline Perspective & Proposed Roles/Actions \\
\hline $\begin{array}{c}\text { Users/ } \\
\text { Manufacturers }\end{array}$ & $\begin{array}{l}\text { - State clearly what they want. } \\
\text { - Demand certification of application system's conformance to key } \\
\text { standards. } \\
\text { - Initiate standards development. }\end{array}$ \\
\hline Researchers & $\begin{array}{l}\text { Provide solutions. } \\
\text { - Identify and build modular engines. }\end{array}$ \\
\hline Societies & - Play active role in industrial standards setting. \\
\hline Government & $\begin{array}{l}\text { - Develop models, infrastructure. } \\
\text { - Fund industry-directed research. } \\
\text { - Initiate conformance testing of relevant standards. }\end{array}$ \\
\hline
\end{tabular}

\section{Research Community Roles and Actions}

The research group considered how the research community could contribute to advancing process planning. In doing so, this group identified specific areas where research is needed, but they also raised several issues that need to be addressed in a broader context to set the direction for future research work. Topics addressed and pertinent comments are shown in Table 18. 
Table 18. Topics Addressed in Research Discussion Group

\begin{tabular}{|c|c|}
\hline Topic Discussed & Issues Raised \\
\hline $\begin{array}{l}\text { Definition of } \\
\text { Process Planning - } \\
\text { dictionary/ ontology }\end{array}$ & $\begin{array}{l}\text { - Need to agree on what to argue over } \\
\text { - Structure } \\
\text { - Example: Software Engineering - data dictionary }\end{array}$ \\
\hline $\begin{array}{l}\text { Data } \\
\text { Representation }\end{array}$ & $\begin{array}{l}\text { - Getting access to the data is the big obstacle to interoperability } \\
\text { - Geometric Dimensioning and Tolerances (GD\&T) } \\
\text { - Computer-interpretable working solution } \\
\text { - Emergent approach... }\end{array}$ \\
\hline $\begin{array}{l}\text { Applications/ } \\
\text { requirements of } \\
\text { new technologies }\end{array}$ & $\begin{array}{l}\text { - Manufacturing "science" - draw similarities between problems } \\
\text { - Problem classification - what techniques to apply? } \\
\text { - Computer assisted process planning } \\
\text { - Information management and feedback } \\
\text { - Open software architectures and development environment }\end{array}$ \\
\hline $\begin{array}{l}\text { Institutional/ } \\
\text { organizational } \\
\text { issues }\end{array}$ & $\begin{array}{l}\text { - Integration research cannot be done on a small scale } \\
\text { - } \quad \text { Mademics need access to real problems } \\
\text { - Government typically pays for students; need coop students with } \\
\text { industry background/support for software, knowledge, data, etc. } \\
\text { - Little research goes beyond one year time frame } \\
\text { - NSF reviewing } \\
\text { - } \quad \text { Little return on investment for support of CAD/CAM API's } \\
\text { - Industry is short term focused } \\
\text { - Need requirements gathering domain education }\end{array}$ \\
\hline
\end{tabular}

\section{Breakout Session Summary}

This final breakout session provided an opportunity for workshop participants to set a course of action for each of the perspectives represented at the workshop. Each group developed specific ideas about the issues to address and options available. In general terms, the user/manufacturer group acknowledged its responsibility for identifying real problems and seeking help from the research community when they cannot solve them within available resources and risk tolerance. The government/ standards organizations see their roles as enablers through funding, testing, leadership, communications/interaction, and standard setting. The research community recognizes the technical challenges they face but sees many of the problems as institutional/cultural barriers to productive research rather than technical limitations. Finally, the vendor/developer community is in the difficult position of trying to anticipate the market for methods and tools so that they focus scarce resources on developing potential highpayoff research products. 


\section{WORSHOP SUMMARY AND NEXT STEPS}

This workshop achieved its objective of providing an opportunity for interaction among the research, development, user, and government agency participants. While every participant was not able to present activities and/or research experience to every other participant, the format encouraged as much interaction as possible among as many as possible within the limited time available. Hopefully, these initial discussions among participants formed the foundation for building future relationships that will move process planning technology development from concept to practice.

Several activities related to the workshop are in progress or will soon commence:

- NIST's Manufacturing Systems Integration Division will use information obtained during this and similar workshops to select and integrate tools that support additional manufacturing engineering functions for than mechanical parts (e.g., assembly planning tools, manufacturing engineering planning validation tools that include inspection and testing, tools that confirm that the virtual machine geometry is within the tolerance of the design geometry).

- NIST is developing methods and models for classifying the motions required to assemble mechanical components so that they can be used to generate the Methods Time Measurement (MTM) cycle times associated with mechanical assembly.

- NIST seeks to develop information models and generic interface specifications that will enable manufacturing engineering planning and validation tools that come from different vendors, and perform different functions, to be integrated into a robust manufacturing engineering environment. Examples include

$\Rightarrow$ Integrating additional process planning software into a process planning environment, including CAME process planning packages and tools for NC development.

$\Rightarrow$ Developing standard interfaces that will enable and support development of process planning based on STEP AP213.

$\Rightarrow$ Integrating Metaphase PDM system into the CAME program.

$\Rightarrow$ Developing a Unified Process Specification Language to support exchange of process information among a wide range of software applications. 


\section{APPENDICES}
A. Workshop Participants
B. Workshop Agenda
C. Program Updates and Keynote Presentations

C1. Computer-Aided Manufacturing Engineering (CAME) Program Overview Chuck McLean

C2. 1996 Process Planning Workshop and CAME Forum

C3. Process Planning: Capturing the Imagination

C4. Mechanical Space

C5. Business and Operations Requirements
Steve Ray

David Bourne

Peter Brooks

Pete Buca 

Appendix A. Workshop Participants

\title{
NIST MANUFACTURING PROCESS PLANNING WORKSHOP
}

\author{
AND \\ CAME FORUM WORKSHOP
}

\section{--List of Participants--}

\author{
June 10-11, 1996 \\ 8:00 AM to 5:00 PM
}

Gaithersburg Marriott Washington Center

9751 Washingtonian Boulevard

Gaithersburg, Maryland 20878 

Donald Bailey

Director of Industrial Programs

Ohio Aerospace Institute

22800 Cedar Point Road

Cleveland, $\mathrm{OH} 44142$

216-962-3050 216-962-3120

DonBailey@oai.org

Dr. David Bourne

Senior Scientist

Carnegie Mellon University

Robotics Institute

Pittsburgh, PA 15213

412-268-7811 412-268-5569

db@BENDING.IMW.RI.CMU.EDU
K. Suzanne Barber

Assistant Professor

The University of Texas

Electrical \& Computer Engineering

24th \& Speedway, ENS 240

Austin, TX 78712

512-471-6152 512-471-3652

barber@mail.utexas.edu

Peter Brooks

Director, Mechanical Products

Bentley Systems, Inc.

690 Pennsylvania Drive

Exton, PA 19341

610-458-2740 610-458-1060

Peter.Brooks@Bentley.COM

Robert G. Brown

President

Deneb Robotics, Inc.

3285 Lapeer Rd. West,

P.O. Box 214687

Auburn Hills, Ml 48321-4687

810-377-6900 810-377-8125

bob@deneb.com

James W. Butler

Staff Technical Programmer Analyst

AlliedSignal Federal Manufacturing \& Technologies

D/A24, E2H8, P.O. Box 419159

Kansas City, MO 64141-6159

816-997-5422 816-997-4094

jwbutler@kcp.com 
Charles "Richard" Burdsal

System Analyst-Process Planning

The Boeing Company

P.O. Box 3707 , M/S 42-74

Seattle, WA 98124-2207

206-655-0703 206-655-1191

rburd@scm1.bems.boeing.com
William D. Cain

Engineering Specialist

Lockheed Martin Energy Systems

P.O. Box 2009, MS 8201, Bldg. 9111

Oak Ridge, TN 37831

423-574-3235 423-574-5458

wdc@ornl.gov (Bill Cain)
Chin-Sheng Chen

Professor

Florida International University

Dept. of Industrial Engineering,

University Park

ECS 416

Miami, FL 33199

305-348-3753 305-348-3721

chenc@cimone.fiu.edu

Kenneth W. Dalgarno

Lecturer

University of Leeds, UK

Department of Mechanical Engineering, Leeds, LS2 9JT

United Kingdom

44-113-233-2234

44-113-233-2150

menkwd@ECU-01.NOVELL.LEEDS.AC.UK

** Debasish Dutta

Associate Professor

University of Michigan

2250 GG Brown Labs,

Mechanical Engineering Dept.,

Ann Arbor, Ml 48109

313-936-3567 313-747-3170

dutta@engin.umich.edu
Mo-yuen Chow

Associate Professor

North Carolina State University

Dept. of Electrical \& Computer

Engineering

Box 7911

Raleigh, NC 27695-7911

919-515-7360 919-515-5523

chow@eos.ncsu.edu

Pooja Dewan

Graduate Student

Penn State University

207 Hammond Building

University Park, PA 16802

814-863-7431 814-863-4745

pooja@wimpy0.PSU.EDU

Donald Elson

Consultant (former V. P. of Technology)

Black \& Decker

M/S TW070, 701 E. Joppa Road

Towson, MD 21286

410-716-3410 410-716-3653

DONALD.ELSON@BDK.COM 
Shaw C. Feng

Mechanical Engineer

NIST

Meteorology Building, Room A-127

Gaithersburg, MD 20878

301-975-3551 301-258-9749

sfeng@ cme.nist.gov

Rick Franzosa

V.P., Sales \& Marketing

CIMx Company

400 TechneCenter Drive

Cincinatti, $\mathrm{OH} 45150$

513-248-7702 513-248-7711

rgf@cimx.com

Chet Fryjoff

Product Manager

Camax Manufacturing Tech

1710 Willow Creek Circle

Eugene, OR 97487

503-687-2631 503-485-0925

chet@camax.com

Daniel M. Gaines

Research Assistant

U. of Illinois at Urbana-Champaign

2413 DCL, 1304 W. Springfield

Urbana, IL 61801

217-244-1263 217-244-8371

dmgaines@cs.uiuc.edu

\author{
** Jim Fowler \\ NIST \\ Building 220, Room A-127 \\ Gaithersburg, MD 20899 \\ 301-975-3180
}

Jon C. Freeman

Product Manager

Boeing Commercial Airplane Group

P.O. Box 3707 M/S 6M-HT

Seattle, WA 98124

206-965-6088 206-965-6766

jf3128@kgv1.bems.boeing.com
Thomas Lee Galyean

Equipment Engineer

Texas Instruments, Inc.

6000 Lemmon Ave., M/S 542

Dallas, TX 75209

214-995-5070 214-995-0221

galyean@texas.dseg.ti.com 
Charles Gilman

STEP Tools, Inc.

Rensselaer Technology Park

100 Jordan Road

Troy, NY 12180

518-276-2061 518-276-8471

gilman@steptools.com

Satyandra K. Gupta, Ph.D.

Project Scientist

Robotics Inst., Carnegie Mellon Univ.

Center for Integrated Manufacturing

Decision Systems, 5000 Forbes Ave.

Pittsburgh, PA 15213

412-268-8780 412-268-5569

Satyandra.K.Gupta@ISL1.RI.CMU.EDU

JungHyun Han

Research Assistant

USC

Computer Science Department

Los Angeles, CA 90089

213-740-4513 213-740-7285

han@lipari.usc.edu

Caroline Clarke Hayes

Assist. Prof. Computer Science

U. of Illinois at Urbana-Champaign

Dept. of Computer Science \& Beckman

Inst.

405 North Mathews Avenue

Urbana, IL 61801

217-333-6071 217-244-8371

hayes@cs.UIUC.EDU
Derek Grant

Project Engineer

Pratt \& Whitney

400 Main Street, M/S 118-38

East Hartford, CT 06108

860-565-3844 860-565-9614

grantda@pweh.com

Stephen N. Haberman

Business Systems Analyst

The Boeing Company

Boeing Commercial Airplane Group

P.O. Box 3707

Seattle, WA 98124

206-965-6091 206-965-6655

300wbmgn@kgv1.bems.boeing.com

Paul Handel

Technical Specialist

Boeing Defense \& Space Group

P.O. Box 16858, M/S P38-50

Philadelphia, PA 19142-0858

610-591-7575 610-591-4948

handelpi@putter.a1.boeing.com

William J. Hlavacek

Manufacturing Engineering Planner

Boeing Commercial Airplane Group

P.O. Box 3707, M/S 6M-HJ

Seattle, WA 98124-2207

206-965-6099 206-965-6655 
** Mark Horner

Boeing Helicopter

P.O. Box 16858, M/S P29-20

Philadelphia, PA 19142-0858

610-591-8913
Keith Hummel

Technical Specialist

Northrop Grumman Corp.

Grumman Data Systems

5800 International Blvd.

N. Charleston, SC 29418

803-760-3493 803-760-3780

hummel@scra.org

Mike Iuliano

Computer Scientist

NIST

Building 220, Room A-127

Gaithersburg, MD 20899

301-975-3891 301-258-9749

iuliano@cme.nist.gov

James A. Joninas

Project Manager

Eastman Kodak Company

901 Elmgrove Road

Rochester, NY 14653-5116

716-726-1712 716-726-7406

joninas@kodak.com
Sanjay Joshi

Associate Professor

Penn State University

207 Hammond Building

University Park, PA 16802

814-865-2108 814-863-4745

sbj@wimpy1.PSU.EDU
Robert P. Judd

Professor

Ohio University

School of Electrical \& Computer Engineering

Athens, $\mathrm{OH} 45701$

614-593-0106 614-593-0007

juddrp@bobcat.ent.ohiou.EDU 
Raju Khanchustambham

DP Technology Corporation

1150 Avenida Acaso

Camarillo, CA 93012

805-388-6000 805-388-3085

** Amy Knutilla

Industrial Engineer

NIST

Building 220/A-127

Gaithersburg, MD 20899

301-975-3514 301-258-9749

knutilla@cme.nist.gov

Tom Laliberty

Raytheon Company

50 Apple Hill Drive

Tewskbury, MA 01876

508-858-5756 508-858-5976

Laliberty_Thomas@caemac.msd.ray.com

Yuan-Shin Lee, Ph.D., P.E.

Assistant Professor

North Carolina State University

Dept. of Industrial Engineering, Box 7906

Raleigh, NC 27695-7906

919-515-7195 919-515-5281

yslee@eos.ncsu.edu
Yong Se Kim

Assistant Professor

University of Illinois-Urbana-Champaign

Dept. of General Engineering

104 S. Mathews Avenue

Urbana, IL 61801-2996

217-333-1180 217-244-5705

yskim@uxl.cso.uiuc.edu

Thomas R. Kramer

Guest Researcher

NIST \& Catholic University

Building 220/B-124

Gaithersburg, MD 20899

301-975-3518 301-990-9688

kramer@cme.nist.gov

\author{
Abhey R. Lamba \\ Developer Support Analyst \\ Bentley Systems, Inc. \\ 690 Pennsylvania Drive \\ Exton, PA 19341 \\ 610-458-2920 610-458-1056 \\ Abhey.Lamba@bentley.com
}

Swee Leong

Manufacturing Engineer

NIST

Building 220/A-127

Gaithersburg, MD 20899

301-975-5426 301-258-9749

leong@cme.nist.gov 
Gordon Little

Research Student

University of Edinburgh

King's Buildings, Mayfield Road,

Edinburgh, EH9 3JL

SCOTLAND

44-131-650-8696

44-131-667-3677

Chuck McLean

Computer Scientist

NIST

Building 220, Room A-131

Gaithersburg, MD 10899

301-975-3511 301-258-9749

mclean@cme.nist.gov

Donald M. Needham

University of Connecticut

Dept.of Computer Science \& Eng.,

170 Davis Road

Storrs, CT 06268

860-429-2545 860-486-4817

needham@eng2.uconn.edu

Charles Parks

Professor \& Chair, Industrial and

Manufacturing Systems Engineering

Ohio University

268 Stocker Center

Athens, $\mathrm{OH} 45701$

614-593-1546 614-593-0778

cparks@bobcat.ent.ohiou.edu
David E. Martin

Sr. Manufacturing Consultant

ICEM Technologies

3505 Bean Creek Road

Scotts Valley, CA 95066

408-438-6641 408-438-6641
Dana S. Nau

Professor

University of Maryland

Dept. of Computer Science and Institute for Systems Research

College Park, MD 20742

301-405-2684 301-405-6707

http://www.cs.umd.edu/ nau

Erroll M. Palmer

Production Control Dept. Head

Naval Ordnance Station Louisville

Code 90A4, NAVSURFWARCEN ORDSTA

5403 Southside Dr.

Louisville, KY 40214-5001

502-364-6592 502-364-6415

ERROLL_P@LOUIS.NOSL.SEA06.NAVY.MIL

Jim Patterson

Technical Specialist

Boeing Defense \& Space Group

P.O. Box 16858, M/S P38-50

Philadelphia, PA 19104-0858

610-591-4345 610-591-4948

pattersonJJ@putter.a1.boeing.com 
Dr. Arati Prabhakar

Director

NIST

Administration Building, Room 1134

Gaithersburg, MD 20899

301-975-2300 301-869-8972

director@ nist.gov

\section{Steven Ray}

Mechanical Engineer

NIST

Building 220, Room !-149

Gaithersburg, MD 20899

301-975-3524 301-258-9749

ray@cme.nist.gov

Frank Riddick

Computer Scientist

NIST

Building 220, Room A149

Gaithersburg, MD 20899

301-975-3524 301-258-9749

riddick@cme.nist.gov

Charles F. Sack, Jr.

Sr. Research Analyst

United Technologies

Pratt \& Whitney Aircraft, MS 118-38

400 Main Street

East Hartford, CT 06108

860-565-3222 860-565-9614

sackcf@pweh.com
Luis C. Rabelo

Associate Professor

Ohio University

Room 274, Stocker Center

Athens, OH 45701

614-593-1542 614-593-0778

rabelo@bobcat.ent.ohiou.edu

Dr. William Regli

NRC Research Associate

NIST

Building 220, Room A-127

Gaithersburg, MD 20899

301-975-4427 301-963-6556

regli@cme.nist.gov

Denny Rock

The Boeing Company

P.O. Box 16858, M/S P28-24

Philadelphia, PA 19142-0858

610-591-3848

rockd@putter.a1.boeing.com
Ezat T. Sanii

Assoc. Professor of Industrial Engineering \& Assoc. Director for Academic Affairs

IMSE Institute

NC State University

Dept. of Industrial Engineering,

Campus Box 7906, 328 Riddick Lab

Raleigh, NC 27695-7906

919-515-7196 919-515-5281

sanii@eos.ncsu.edu 
Dr. Linda C. Schmidt

Assistant Professor

University of Maryland

Dept. of Mechanical Engineering

College Park, MD 20742-3035

301-405-0417 301-314-9477

Ischmidt @eng.umd.edu

J. MacGregor Smith

Professor

University of Massachusetts

Dept. of Mechanical \& Industrial

Engineering Box 32210

Amherst, MA 01003-2210

413-545-4542 413-545-1027

JMSMITH@ecs.umass.edu

Dusan N. Sormaz

Assistant Professor

Ohio University

280 Stocker Center

Athens, $\mathrm{OH}$ 45701-2979

614-593-1548 614-593-0778

sormaz@bobcat.ent.ohiou.edu

Simon Szykman

Mechanical Engineer

NIST

Building 304, Room 12

Gaithersburg, MD 20899

301-975-4466 301-926-3842

szykman@cme.nist.gov
David E. Schmitz

Professor of Engineering Management

Defense Systems Management College

9820 Belvoir Road, ATTN: FDMM

Ft. Belvoir, VA 22060-5565

703-805-3765 703-805-3721

schmitz@dsmc.dsm.mil

Michael C. Smith

Senior Scientist

SAIC

1710 Goodridge Drive, M/S 1-7-6

McLean, VA 22102

703-827-4772 703-893-2187

michael.c.smith@cpmx.saic.com

Dr. Ram D. Sriram

Group Leader, Engineering Design

Technologies

NIST Manufacturing Systems Integration

Building, Room A127

Gaithersburg, MD 20899-0001

301-975-3507 301-258-9749

sriram@cme.nist.gov

Dominick Terra

Senior Applications Engineer

ADRA Systems, Inc.

301 Lindenwood Drive, Suite 1

Malvern, PA 19355

610-640-3122 610-640-3105

terra@adra.com 
John M. Usher

Associate Professor

Mississippi State University

Dept. of Industrial Engineering

P.O. Box 9542/125 McCain Bldg.

Miss. State, MS 39762

601-325-7624 601-325-7618
Yu (Michael) Wang

Assistant Professor

University of Maryland

Dept. of Mechanical Engineering, Bldg. 2181

College Park, MD 20742-3035

301-405-0416 301-314-9477

yuwang@eng.umd.edu

Derek Michael Yip-Hoi

Doctoral Student

University of Michigan

Dept. of Mechanical Engineering

2289 G.G. Brown Laboratory

Ann Arbor, MI 48109-2125

313-763-4056 313-747-3170

yiphoi@engin.UMICH.EDU

*Irvin M. Bohr

Manufacturing Support Manager

Black \& Decker

U.S. Power Tools Group, MS 150

701 East Joppa Road

Towson, MD 21286

410-716-2808 410-716-32453

*Greg Carroll

Syntek

4301 North Fairfax Drive

Arlington, VA 22203

702-525-3403 703-525-0833
*Michael R. Duffey

George Washington University

$2130 \mathrm{H}$. Street, NW

Washington, DC 20817

202-994-7173 202-994-4606

duffey@seas.gwu.edu
*Stephen Klomparens

Vice President

Syntek

4301 North Fairfax Drive

Arlington, VA 22203

702-525-3403 703-525-0833

shklomp@interramp.com 
* Zhi-Kui Ling

IPA

Michigan Tech

Mechhanical Engineering Department

Houghton, Ml 49931

906-487-2620 906-487-2822

ling@mtu.edu

* Kevin Lyons

Mechanical Engineer

NIST

Building 304, Room 12

Gaithersburg, MD 20899

301-975-6550

klyons@cme.nist.gov

${ }^{\text {* Dr. Venkat Rajan }}$

Guest Researcher

NIST

Building 304, Room 12

Gaithersburg, MD 20899

301-975-6543

rajan@cme.nist.gov
* Avouk Loreau

Guest Researcher

NIST

Gaithersburg, MD 20899

301-975-5446

Avoukloreau@ nist.gov

* Prasad Mandava

University of Maryland

6108 Breezewood Drive, \#204

Greenbelt, MD 20770

301-474-0889

mandava@cme.nist.gov
* Craig Schlenoff
Mechanical Engineer
NIST
Building 220, Room A127
Gaithersburg, MD 20899
301-975-6536 301-258-9749
schlenof@cme.nist.gov

* Bob Tuttle

Research Engineer

Heriot-Watt University

Department of Mechnical \& Chemical

Engineering, Riccarton

Edinburgh, SCOTLAND EH14 4AS

44131447514 Ext. 4343

b.tuttle@ hw.ac.uk 



\section{Appendix B. Workshop Agenda}

\section{NIST Manufacturing Process \\ Planning Workshop and \\ CAME Forum Workshop}

June 10-11, 1996

8:00 AM to 5:00 PM

Grand Ballroom

Gaithersburg Marriott Washington Center 9751 Washingtonian Boulevard

Gaithersburg, MD 20878

\section{Agenda - Monday, June 10}

Continental Breakfast

Welcome and Introduction

Workshop Purpose and Objectives

CAME Forum Update

Manufacturing Process Planning Update

Break

Breakout Session I (Futures -general)

- Research: What are the new technologies that will facilitate manufacturing integration and process planning? What are the major technical hurdles and research challenges?

- Development/Vendor: What do you see as the next generation tools being used? What are the key enabling technologies?

- Users: What are the critical information technology needs/challenges that affect competitiveness? What are the elements of the business case that will lead to their adoption?

Report Out I

Lunch

Keynote Address

Questions and Discussion

Breakout Session II (Futures - specific)

- Topic 1: What will become the dominant information technology paradigm for manufacturing engineering and process planning?

- Topic 2: How will manufacturing integration and process planning technologies effect the next business "culture" (and vice-versa)?

- Topic 3: What manufacturing domains beyond machining are attractive targets for integration and process planning technologies?

Break

Report Out II

Plenary Discussion

Adjourn
Spokespersons

8:00-8:30 AM

8:30-8:45 AM

8:45-9:00 AM

9:00-9:30 AM

McLean

Dr. Steven Ray

9:30-10:00 AM

10:00-10:15

AM

10:15-11:45

AM

$11: 45-12: 30$

PM

12:30-1:00 PM

1:00-1:45 PM

Carnegie-Mellon U.

1:45-2:00 PM

2:00-3:30 PM

3:30-3:45 PM

Spokespersons

3:45-4:30 PM

Facilitator

4:30-5:00 PM

5:00 PM 


\section{NIST Manufacturing Process \\ Planning Workshop and CAME \\ Forum Workshop}

June 10-11, 1996

8:00 AM to 4:45 PM

Grand Ballroom

Gaithershurg Marriott Washington

Center

9751 Washingtonian Boulevard

Gaithersburg, MD 20878

\section{Agenda - Tuesday, June 11}

Continental Breakfast

Workshop Review

Keynote

Questions and Discussion

Breakout Session III (Technology focus -- specific topics to be determined based on participants' interests)

Break

Report Out III

Keynote

Lunch

Breakout Session IV ("mixed" membership groups)

- Research: What is the appropriate role of the research community in addressing manufacturing integration and process planning needs?

- Development/Vendor: What is the appropriate role of vendors in addressing manufacturing integration and process planning needs?

- Users: What is the appropriate role of users in addressing manufacturing integration and process planning needs?

- Gov't/Stds Organizations: What is the appropriate role of government and standards organizations in addressing manufacturing integration and process planning needs?

Report Out IV

Break

Moderated Panel Session

Workshop Wrap-up

Adjourn
8:00-8:30 AM

Facilitator

8:30-8:45 AM

Pete Buca

8:45-9:30 AM

Parker Hannifin Corp.

9:30-9:45 AM

Facilitator

9:45-10:45 AM

10:45-11:00 AM

Spokespersons

11:00-11:30 AM

Peter Brooks

11:30-12:15 PM

Bentley Systems, Inc.

12:15-1:00 PM

Facilitator

1:00-2:30 PM
2:30-3:15 PM

3:15-3:30 PM

Spokespersons (III \& IV)

3:30-4:15 PM

Facilitator

4:15-4:30 PM

4:30 PM 


\section{Appendix C. Program Updates and Keynote Presentations}

- Computer-Aided Manufacturing Engineering (CAME) Program Overview

- 1996 Process Planning Workshop and CAME Forum

- Process Planning: Capturing the Imagination

- Mechanical Space

- Business and Operations Requirements
Chuck McLean

Steven Ray

David Bourne

Peter Brooks

Pete Buca 


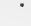




\section{Appendix C1}

Computer-Aided Manufacturing Engineering (CAME) Program Overview 

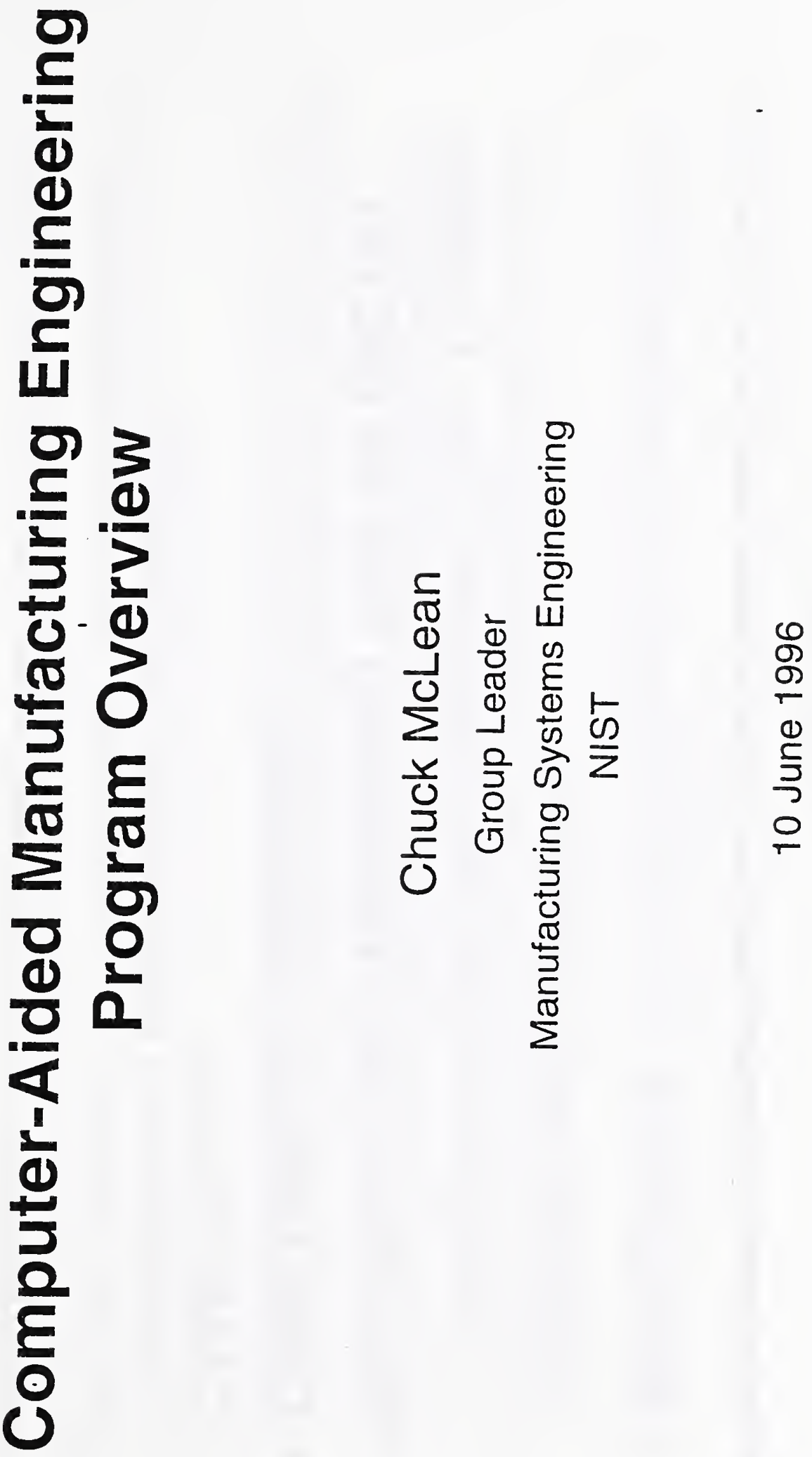


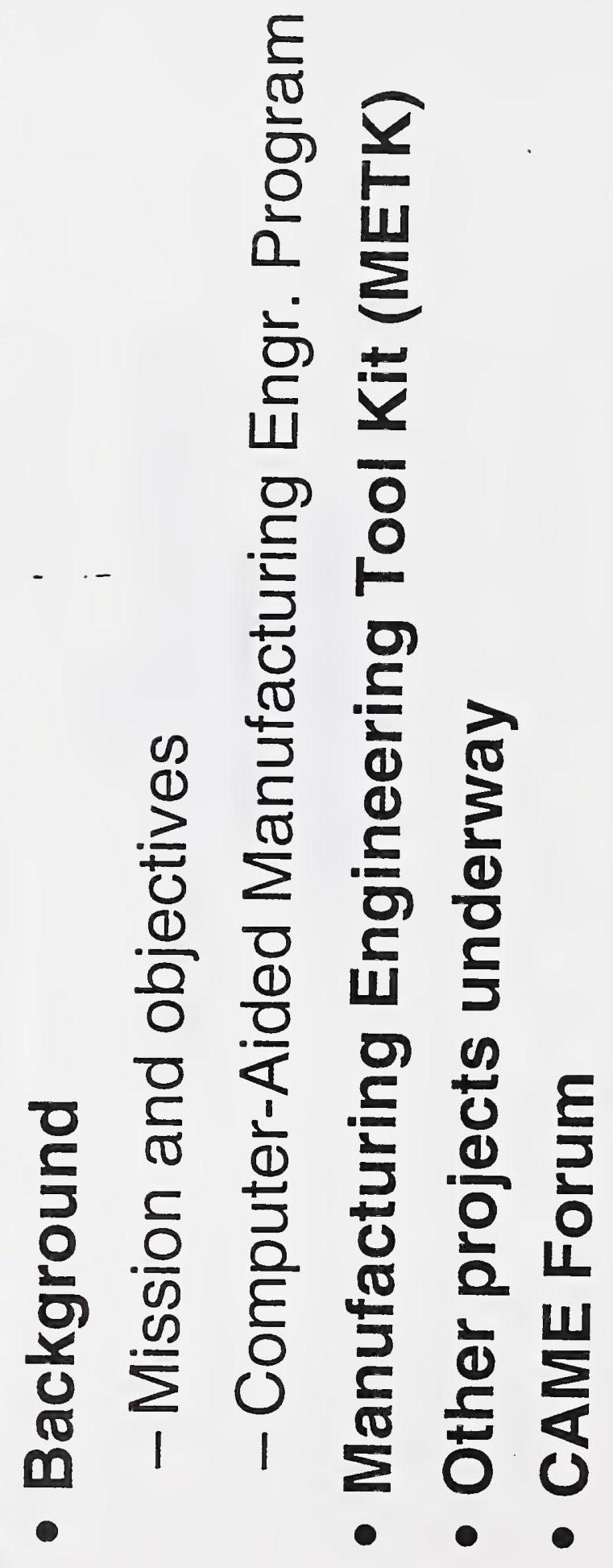




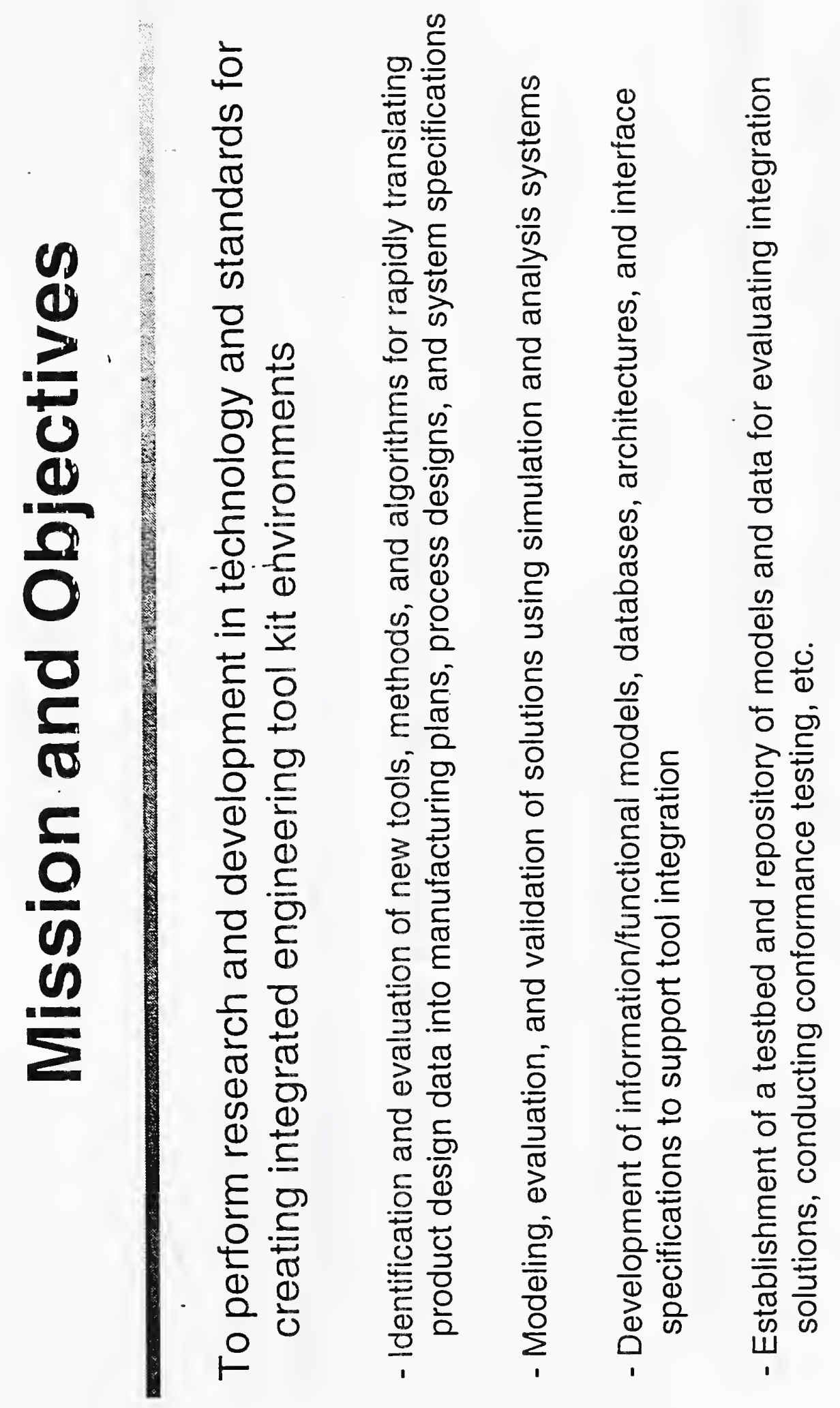




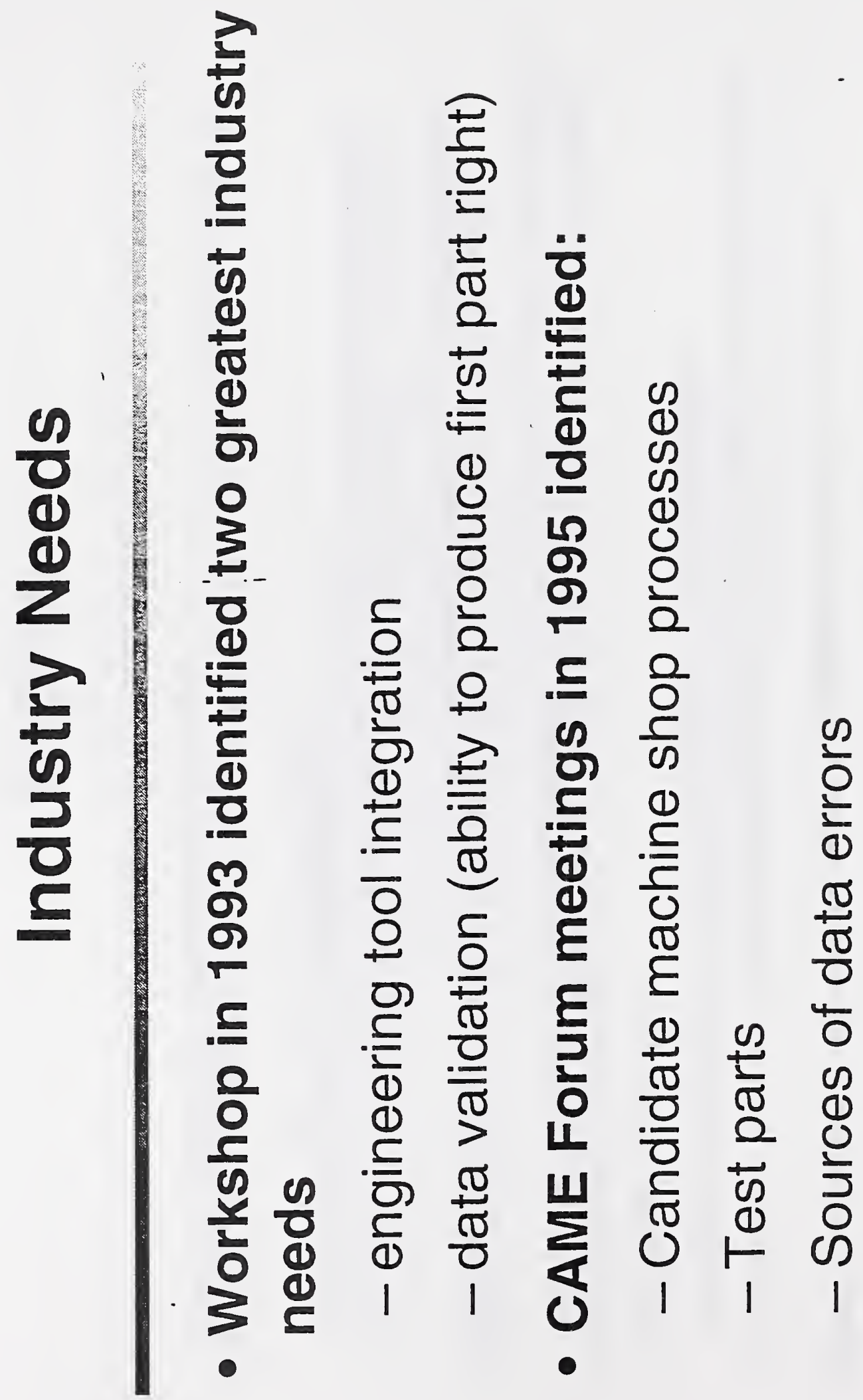

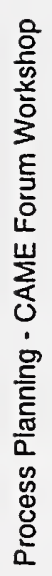

$\frac{8}{9}$
$\frac{9}{9}$
5
5
0 


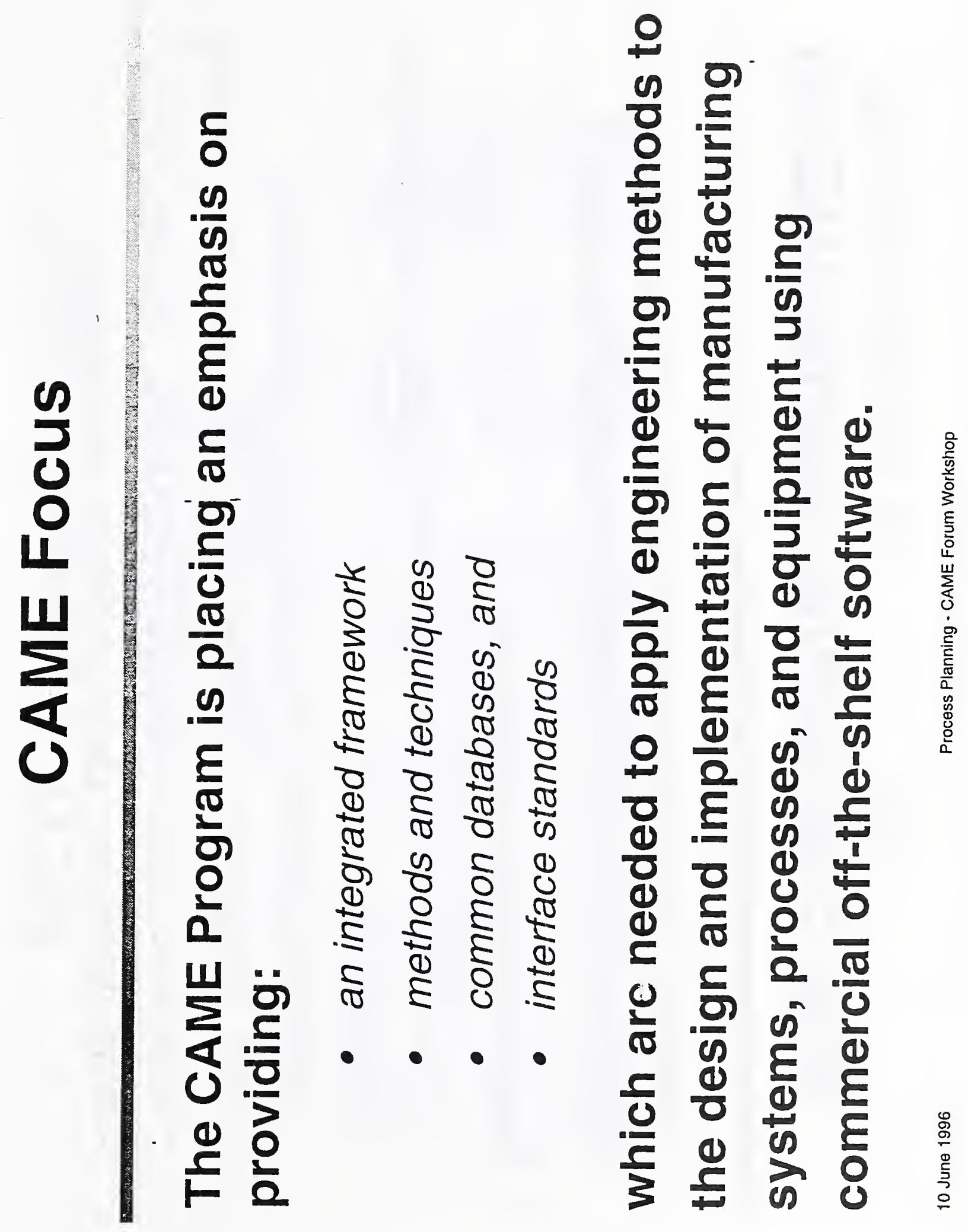




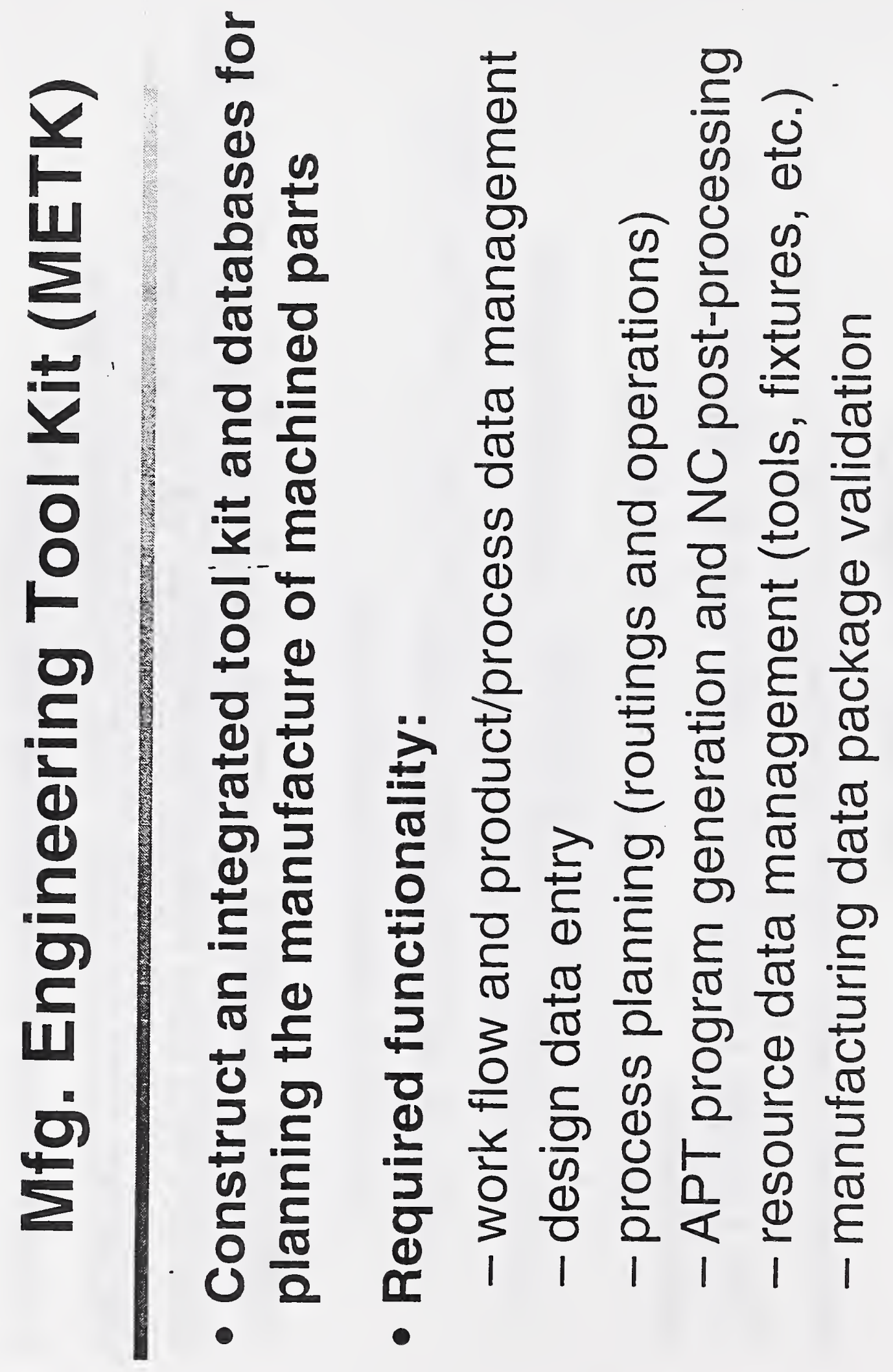




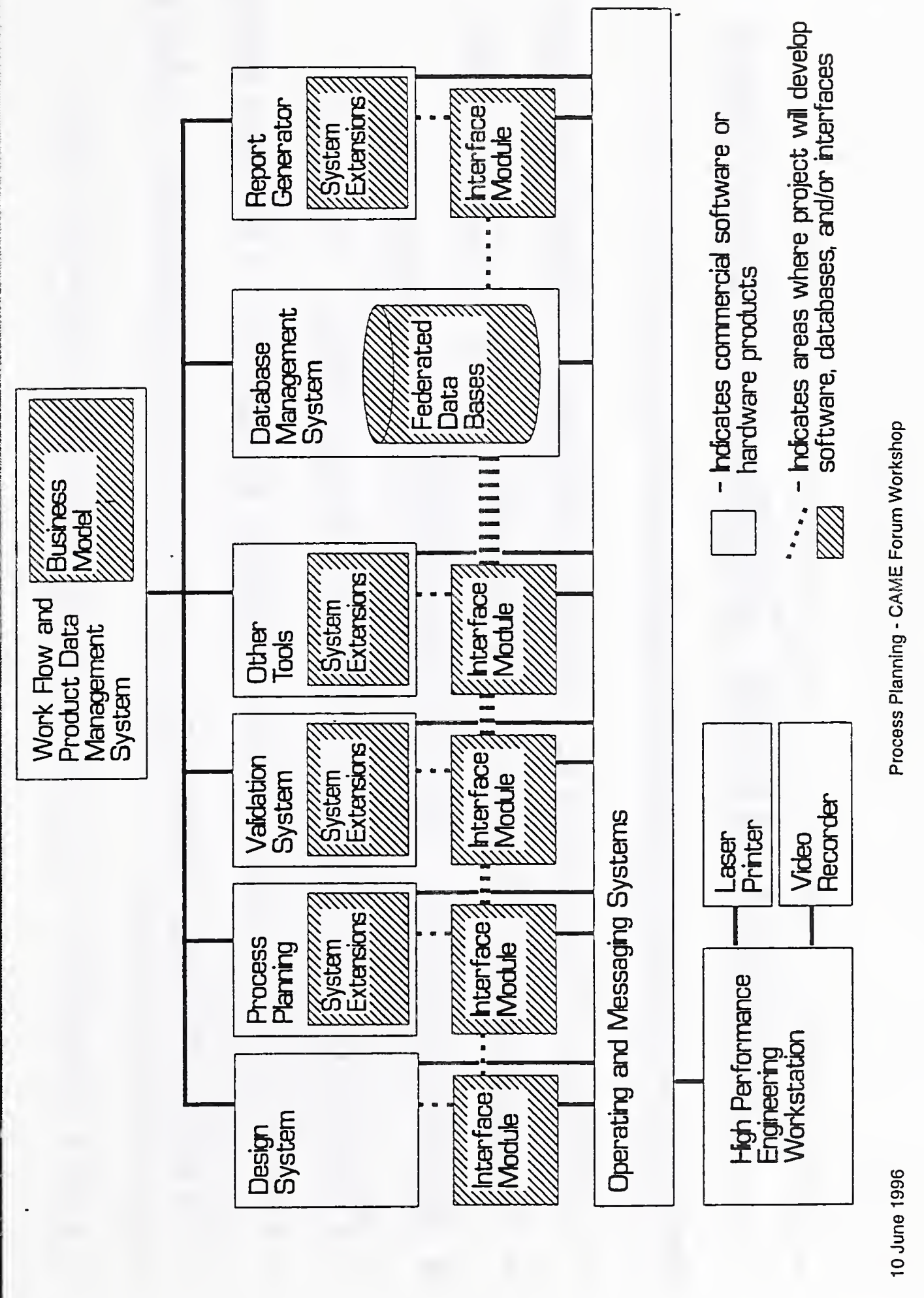




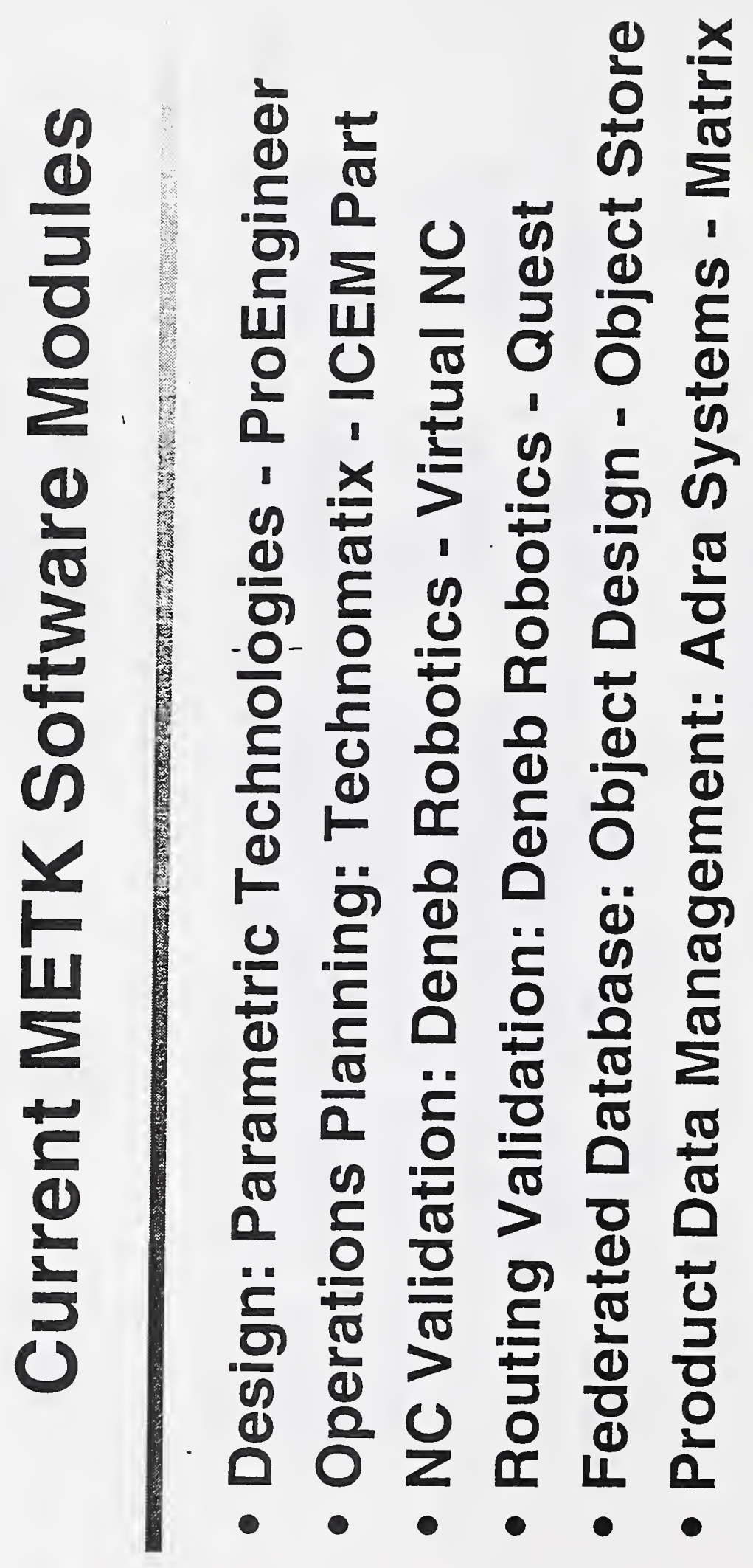




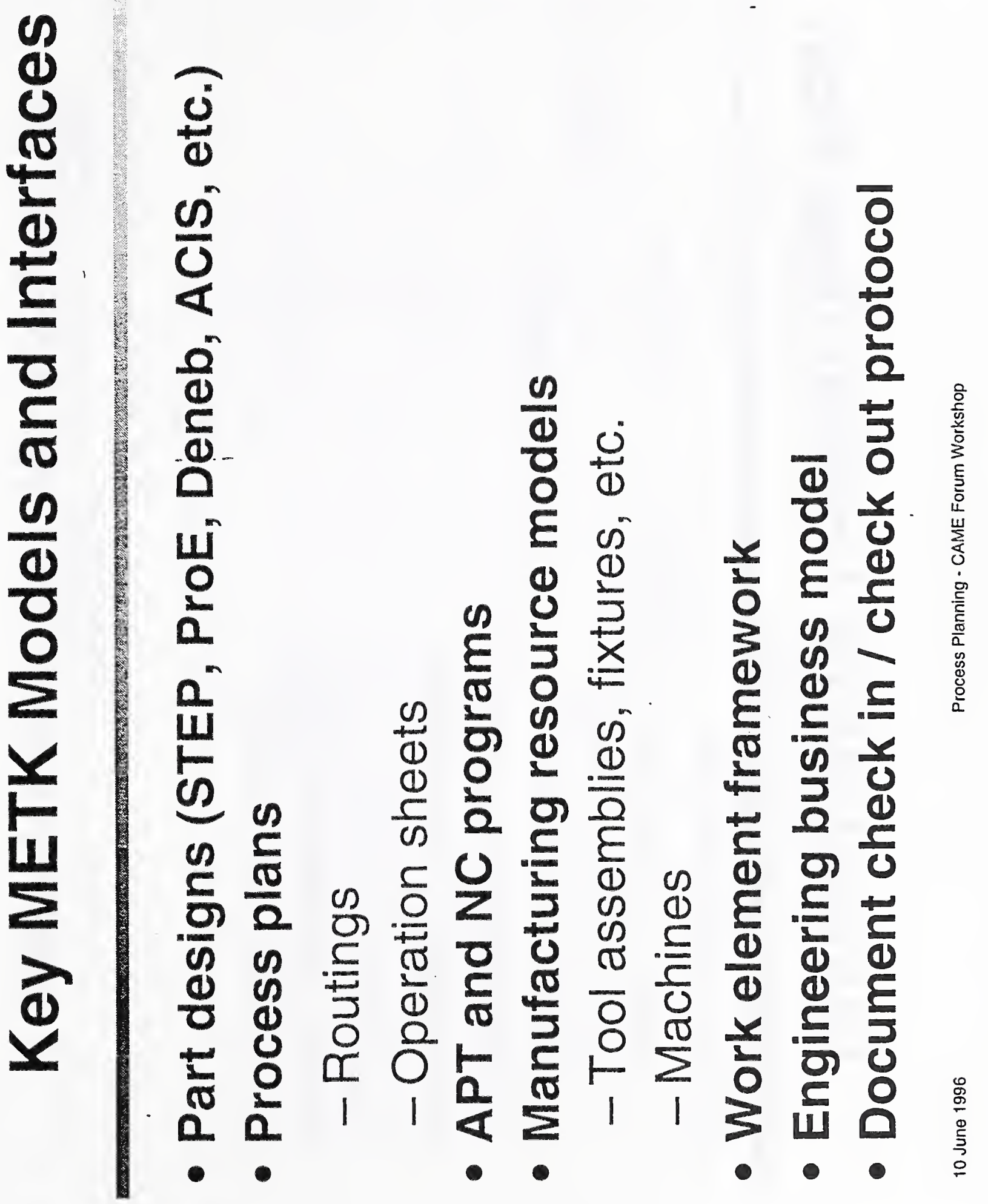




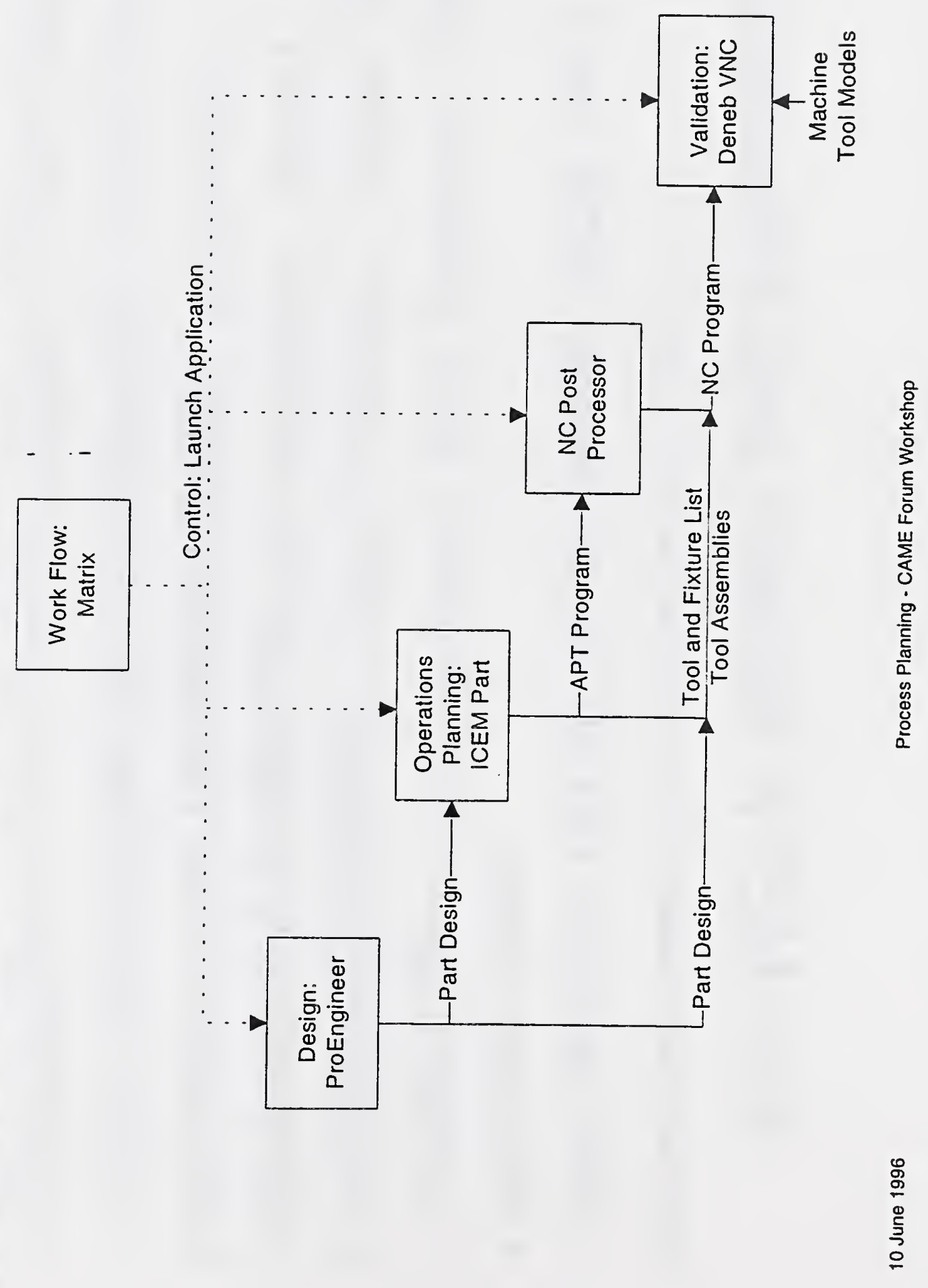




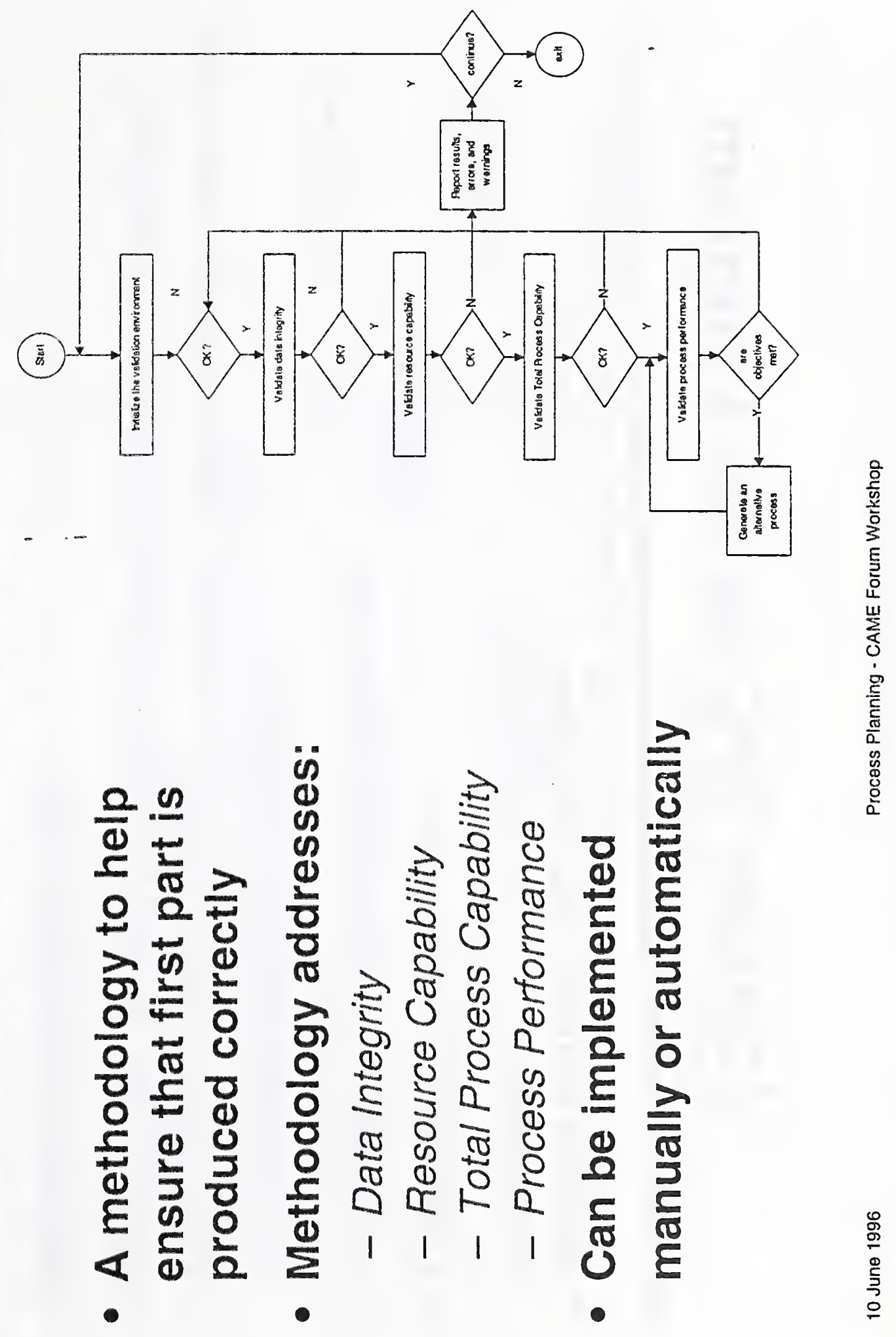




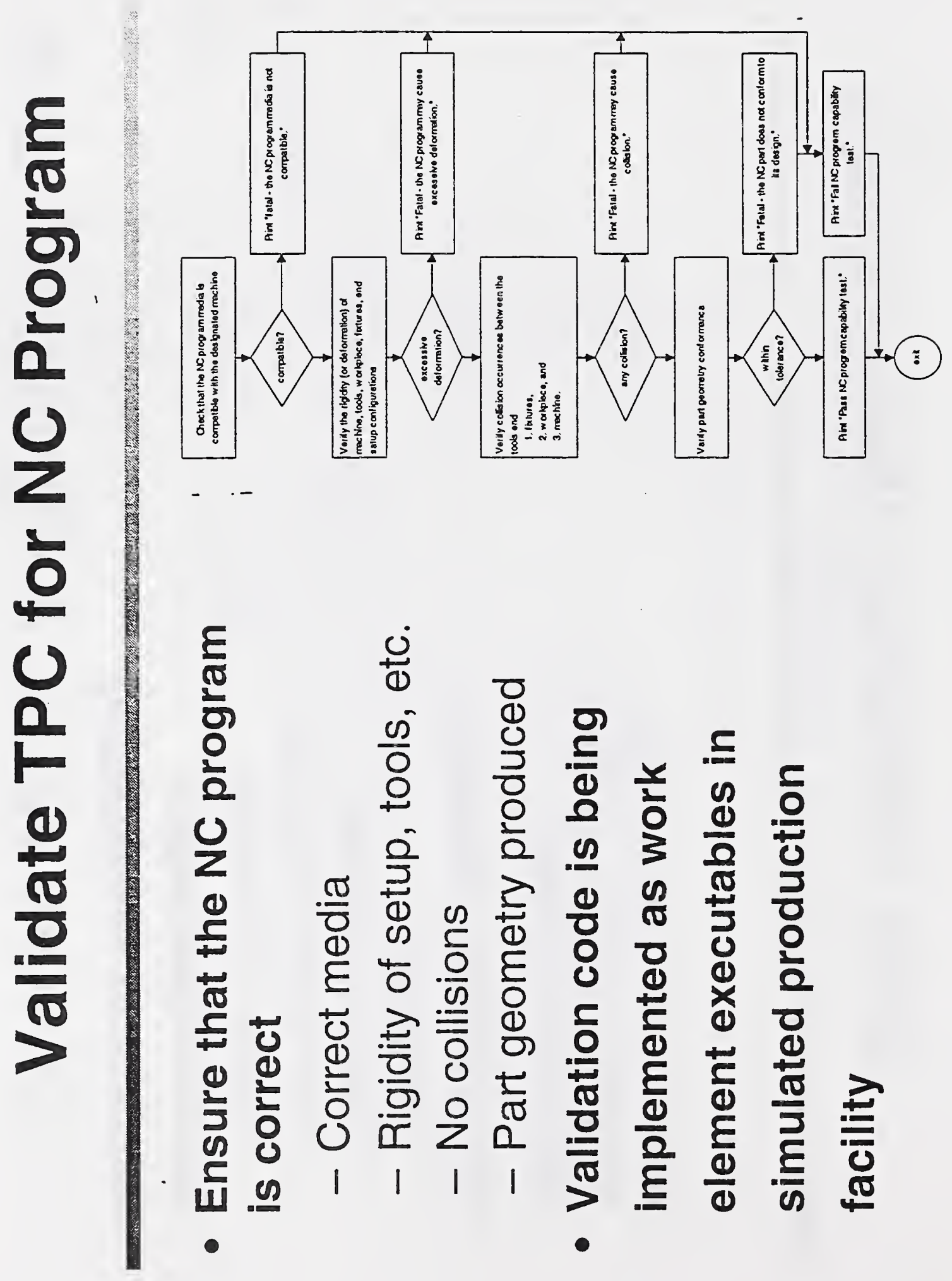

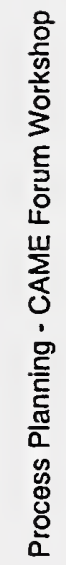

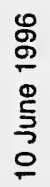




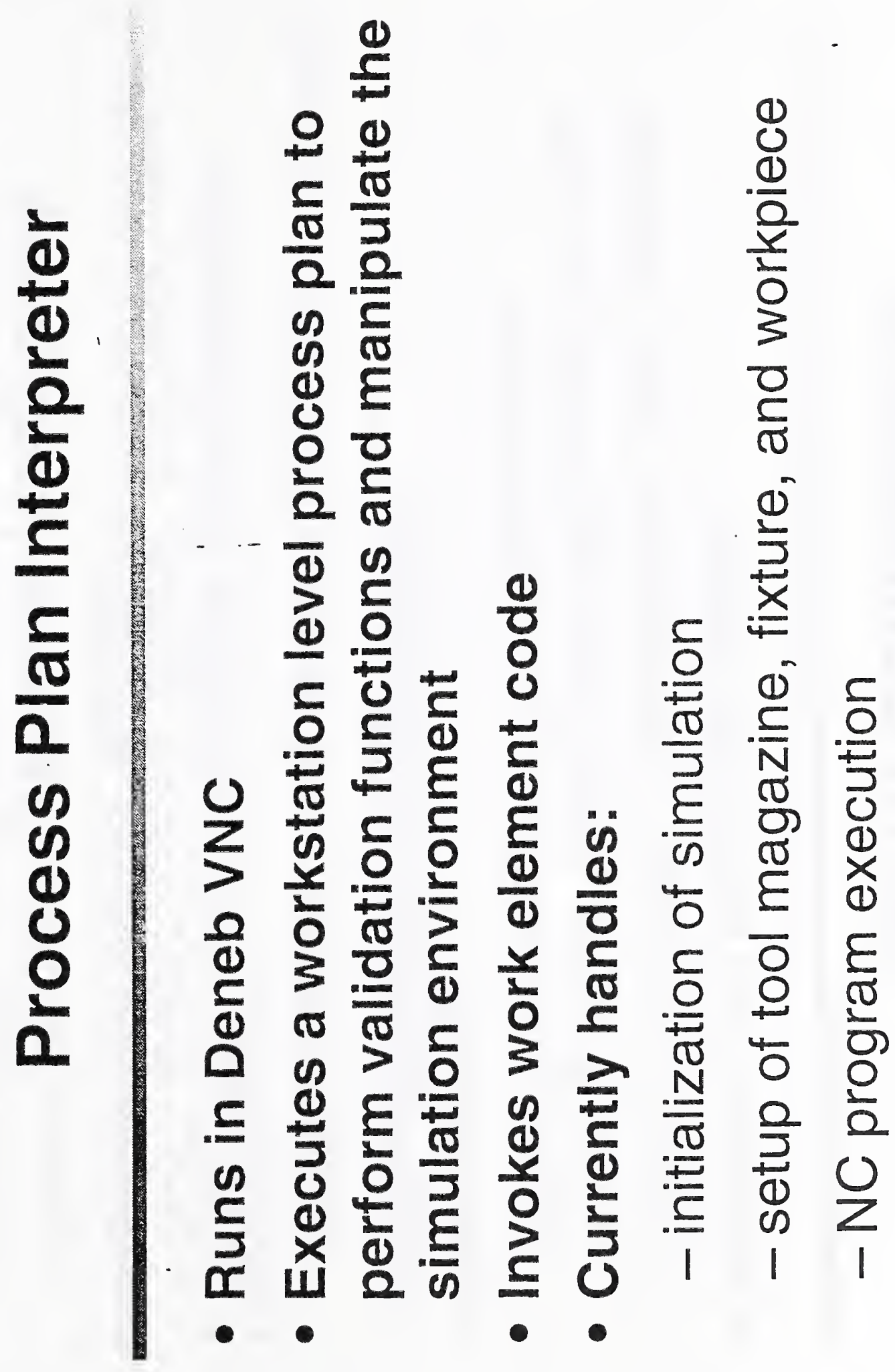




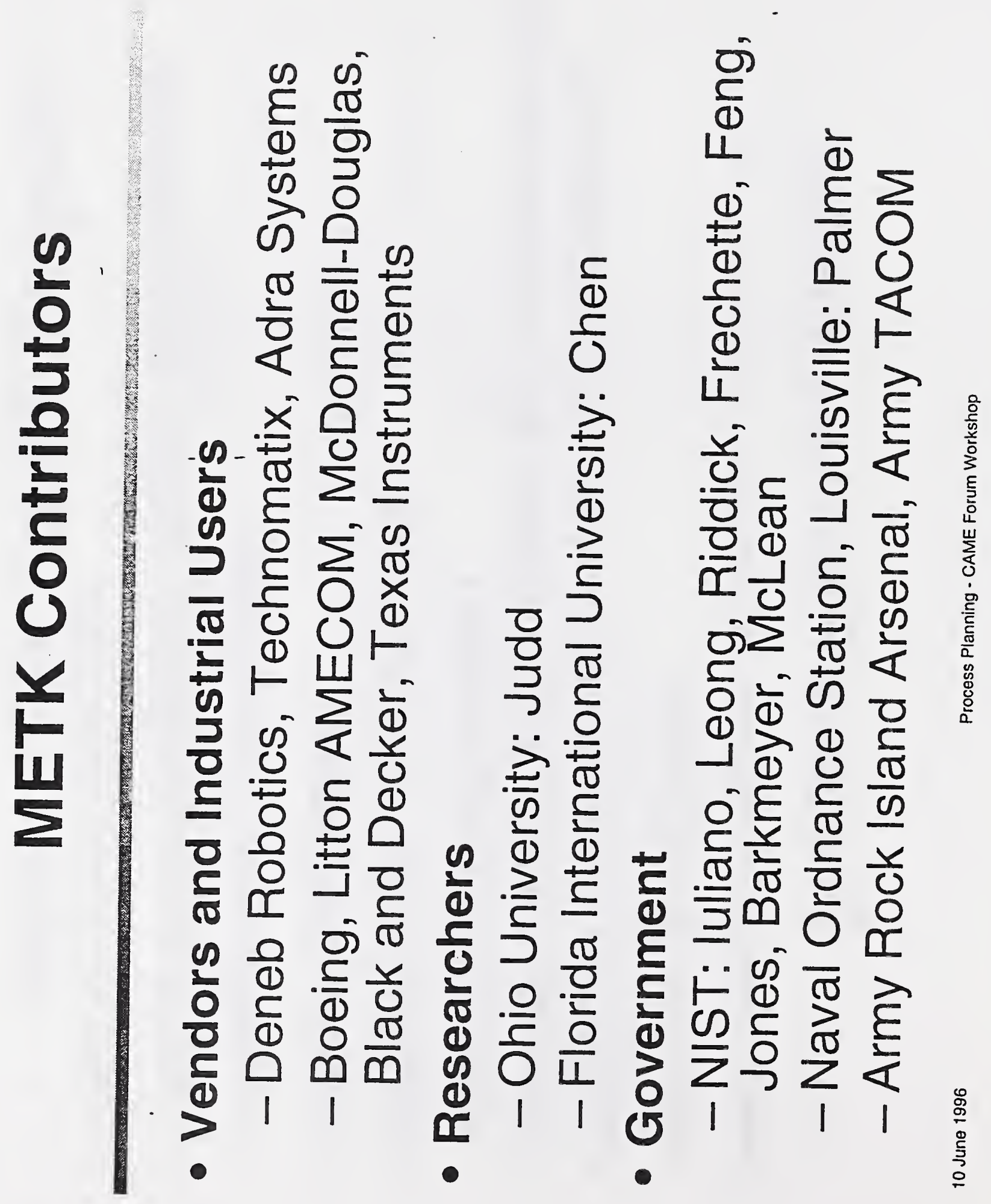




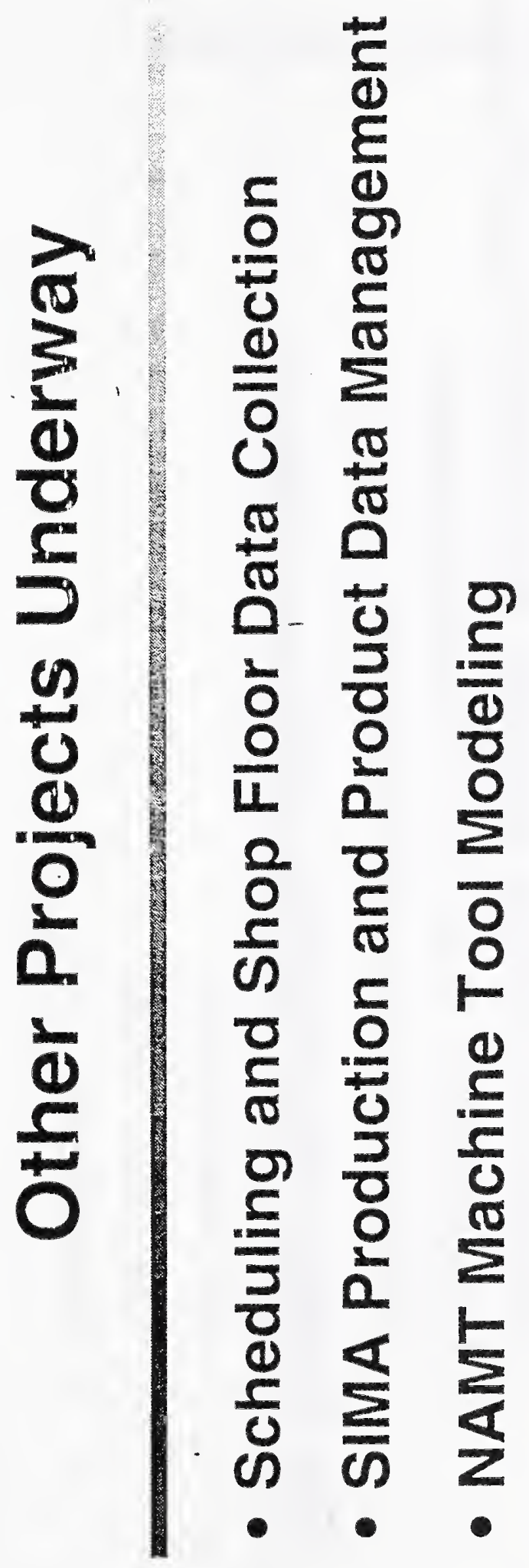




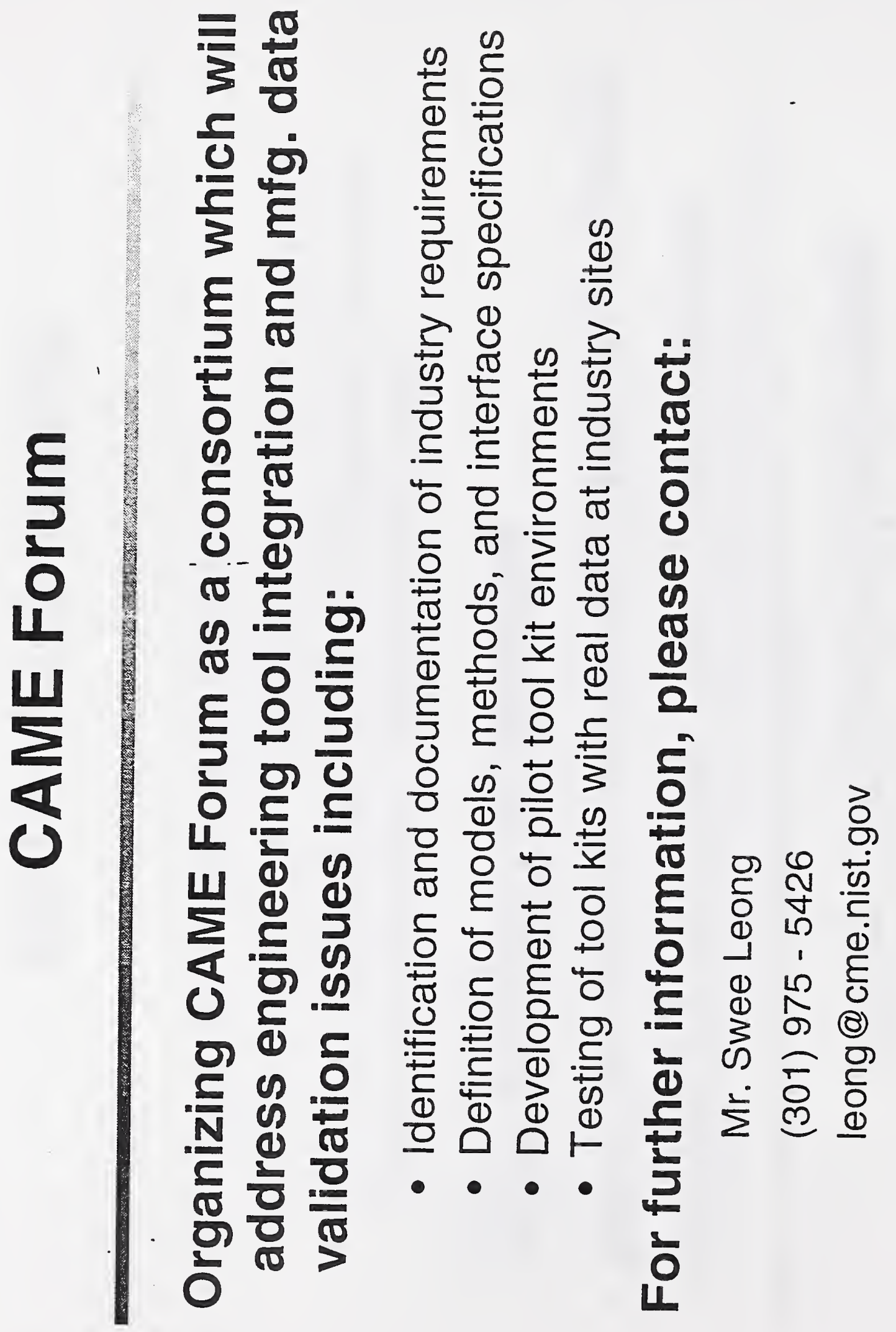




\section{Appendix C2}

1996 Process Planning Workshop and CAME Forum 


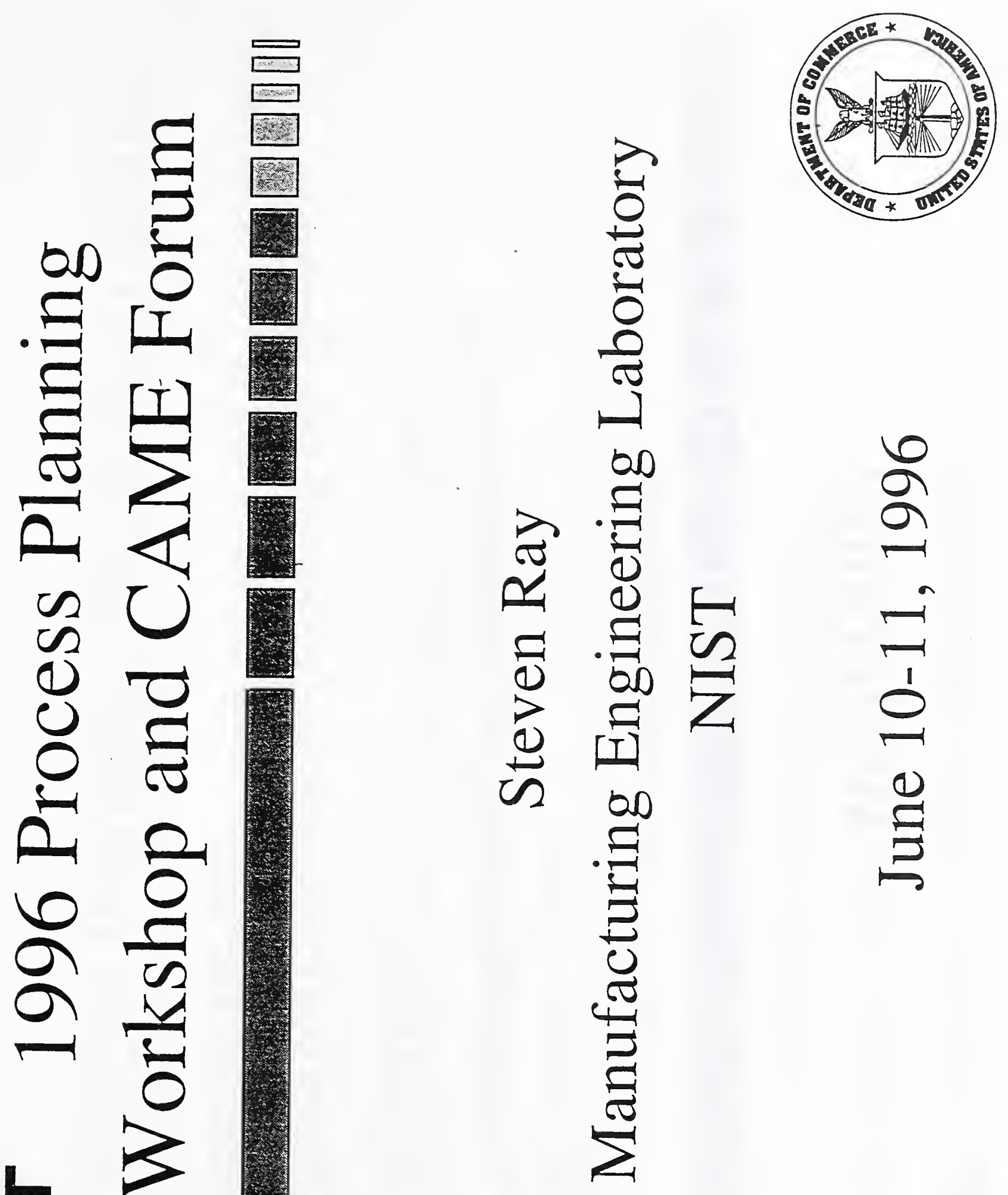


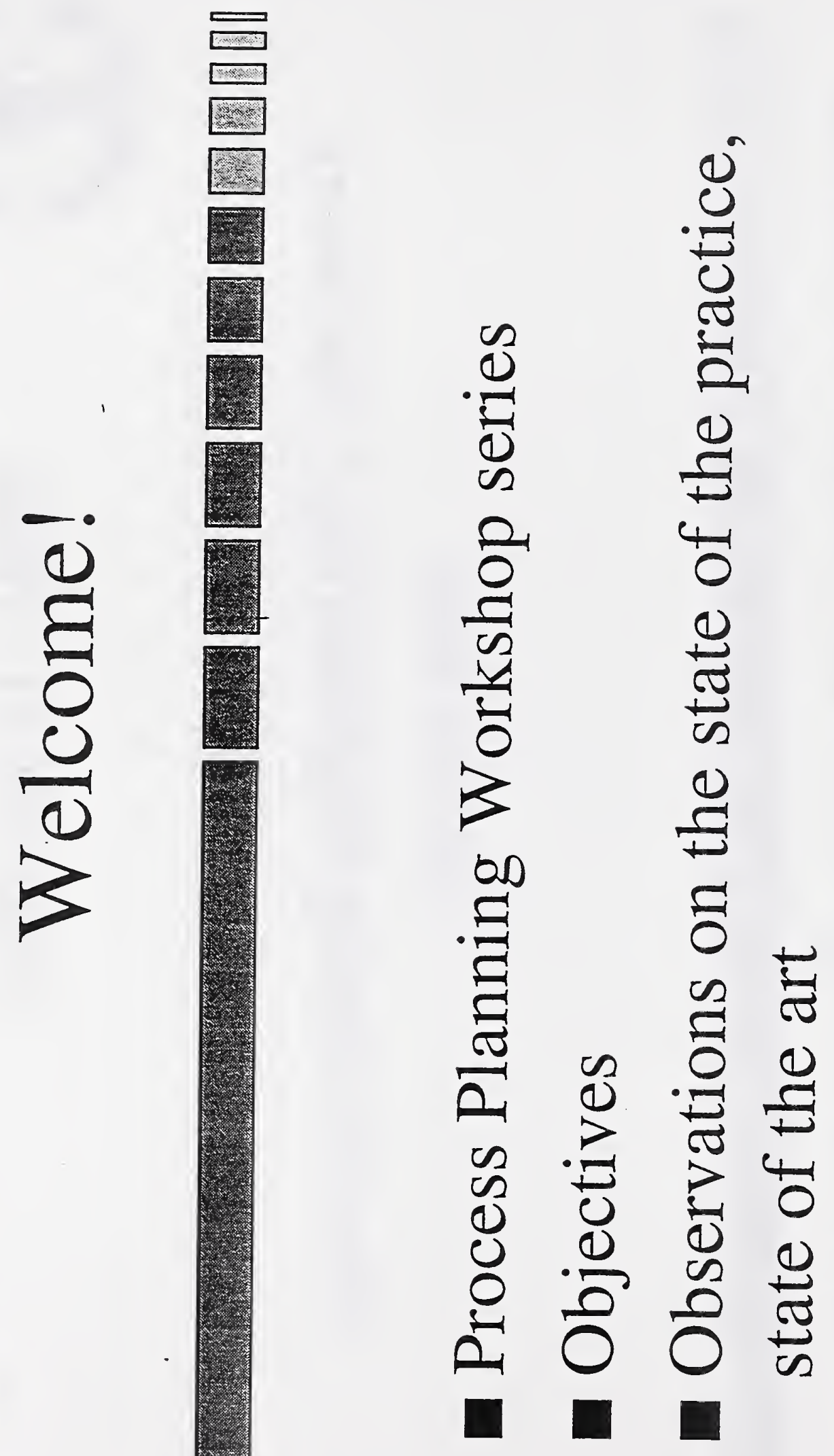




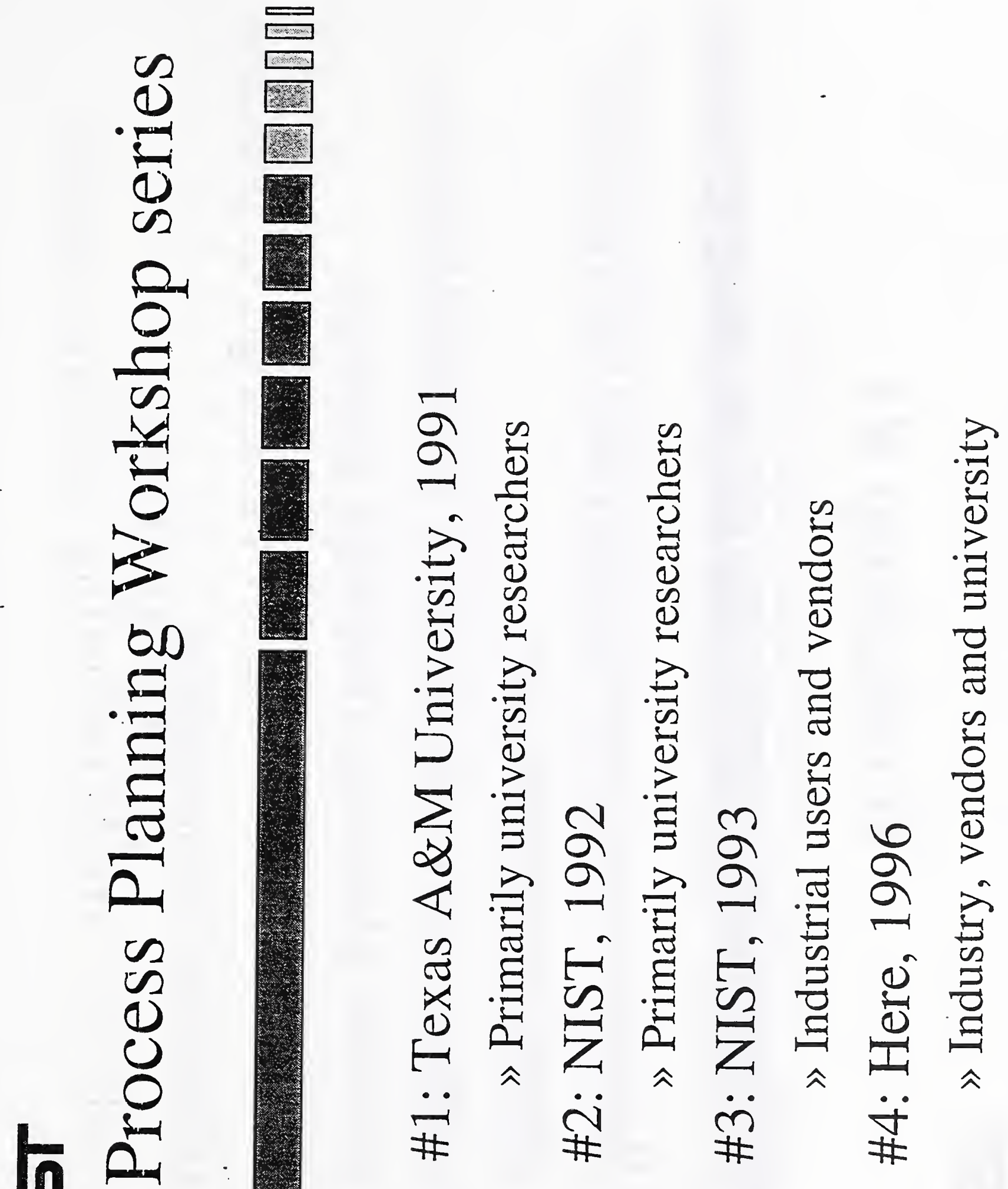




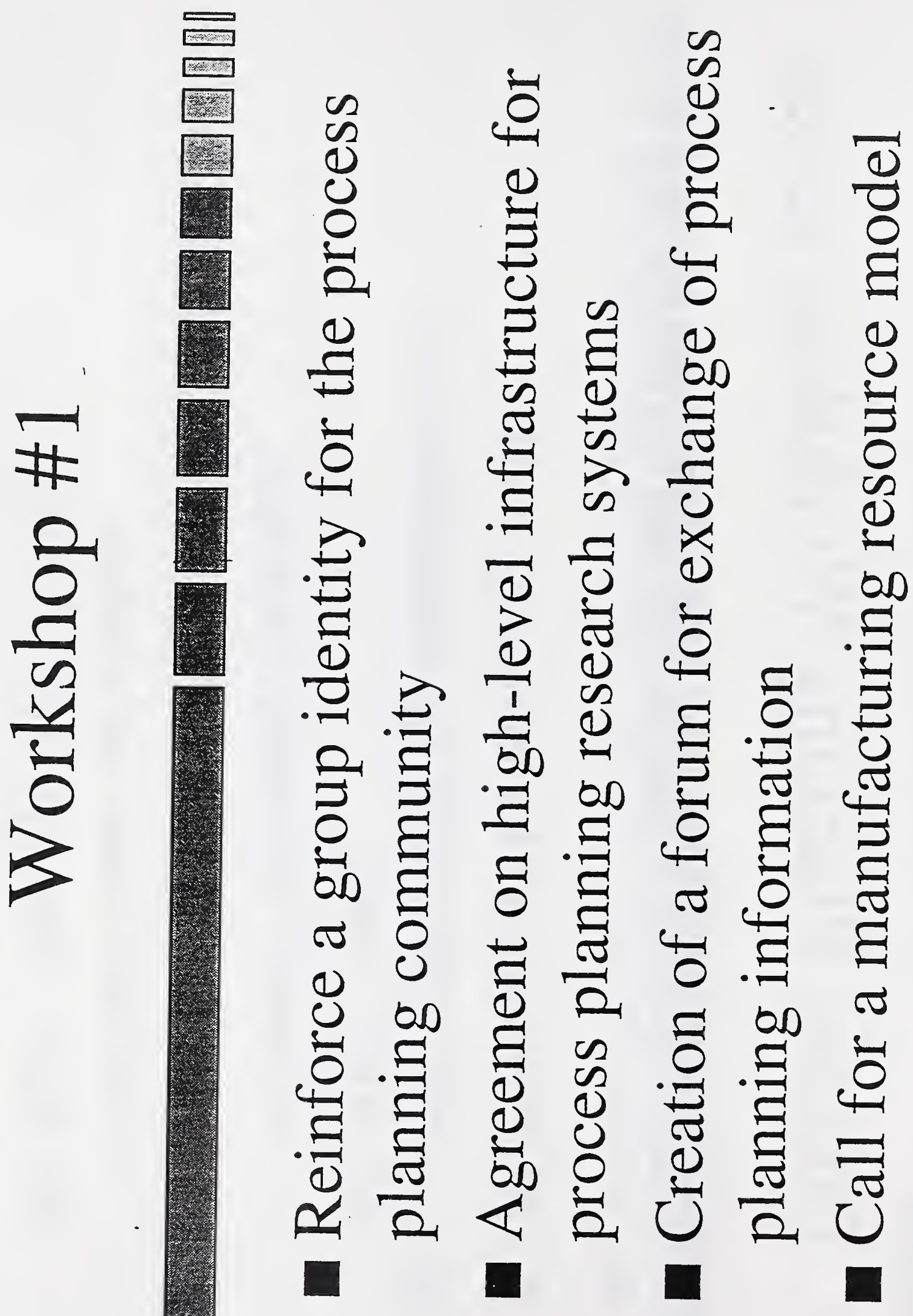




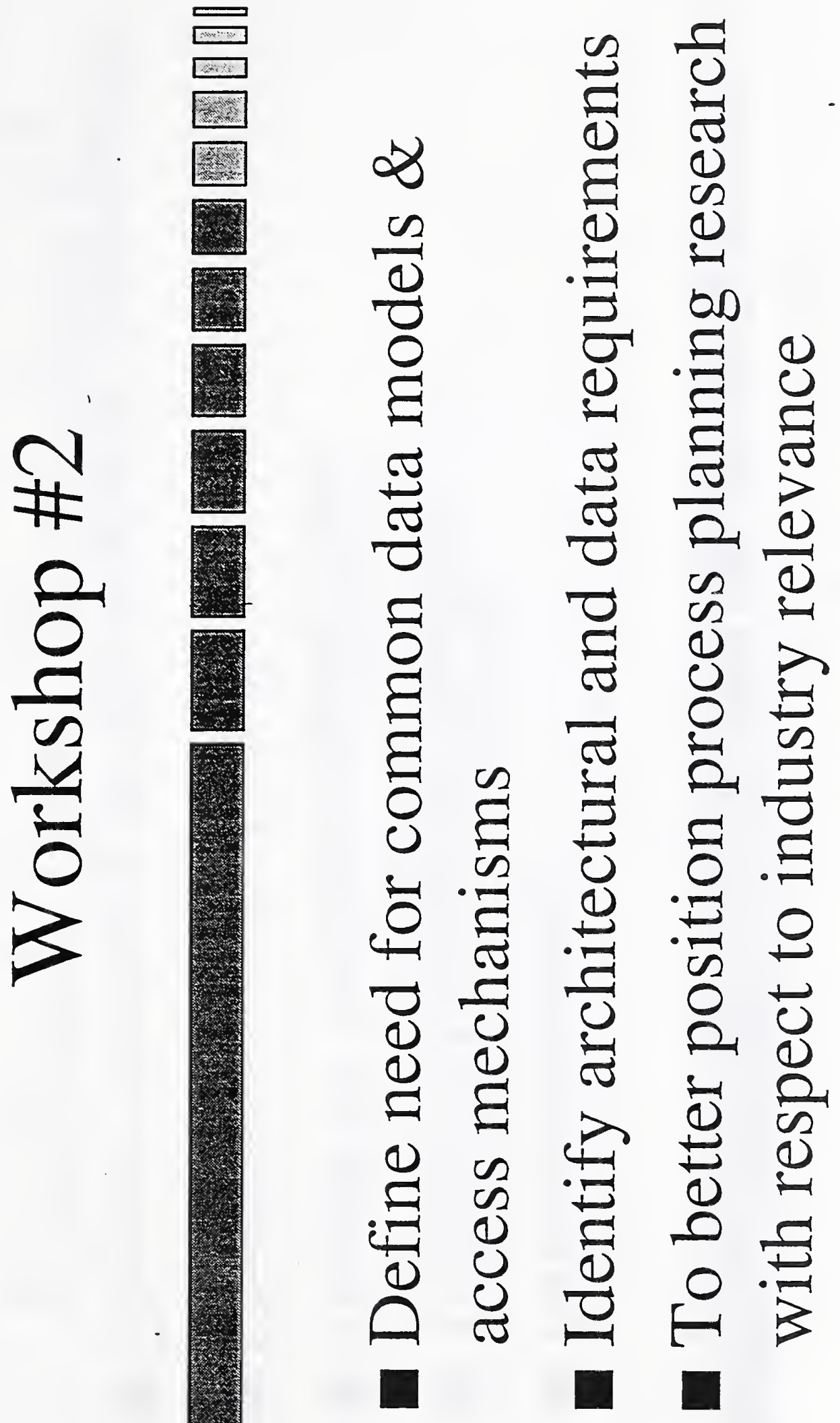




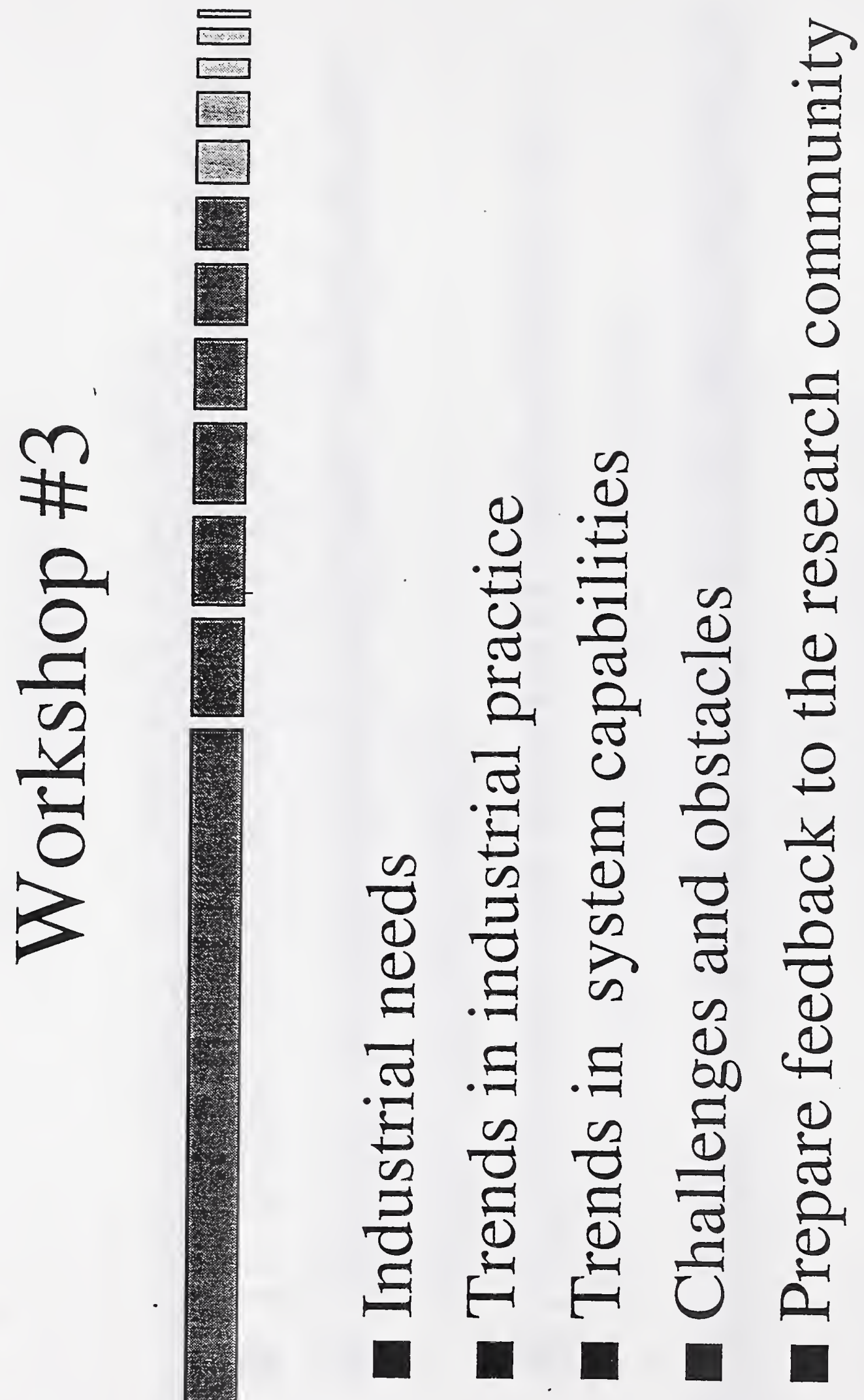




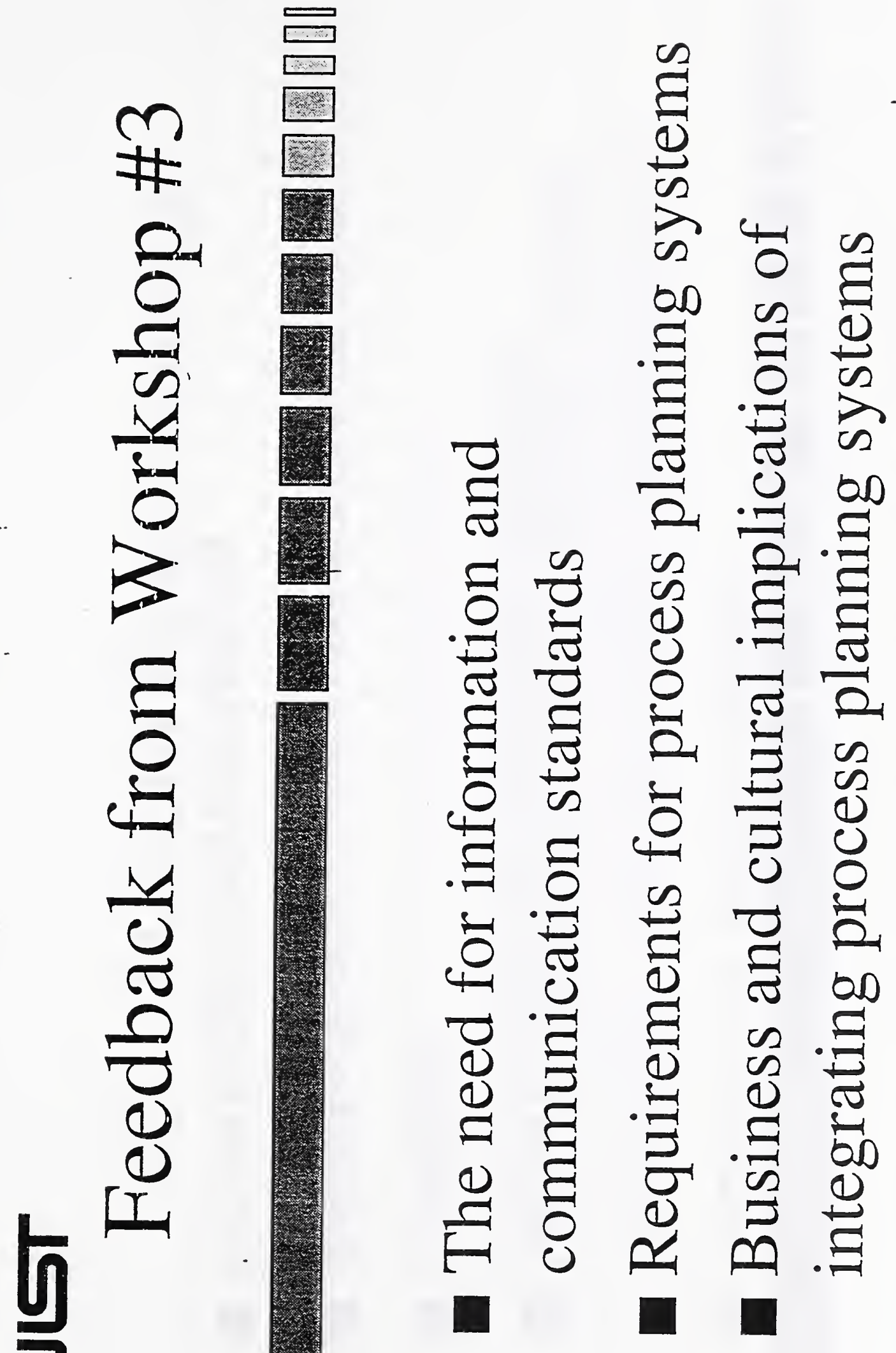




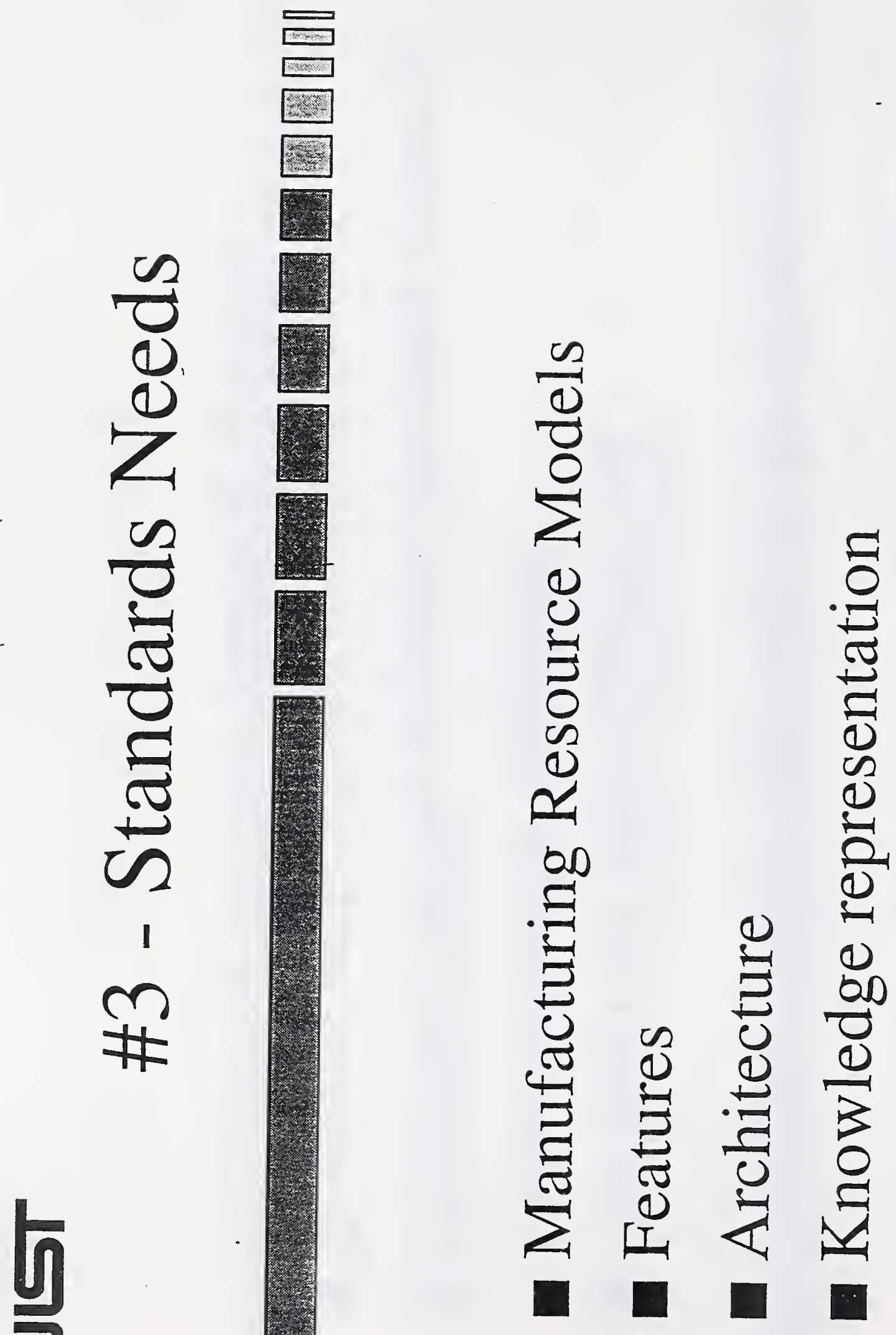




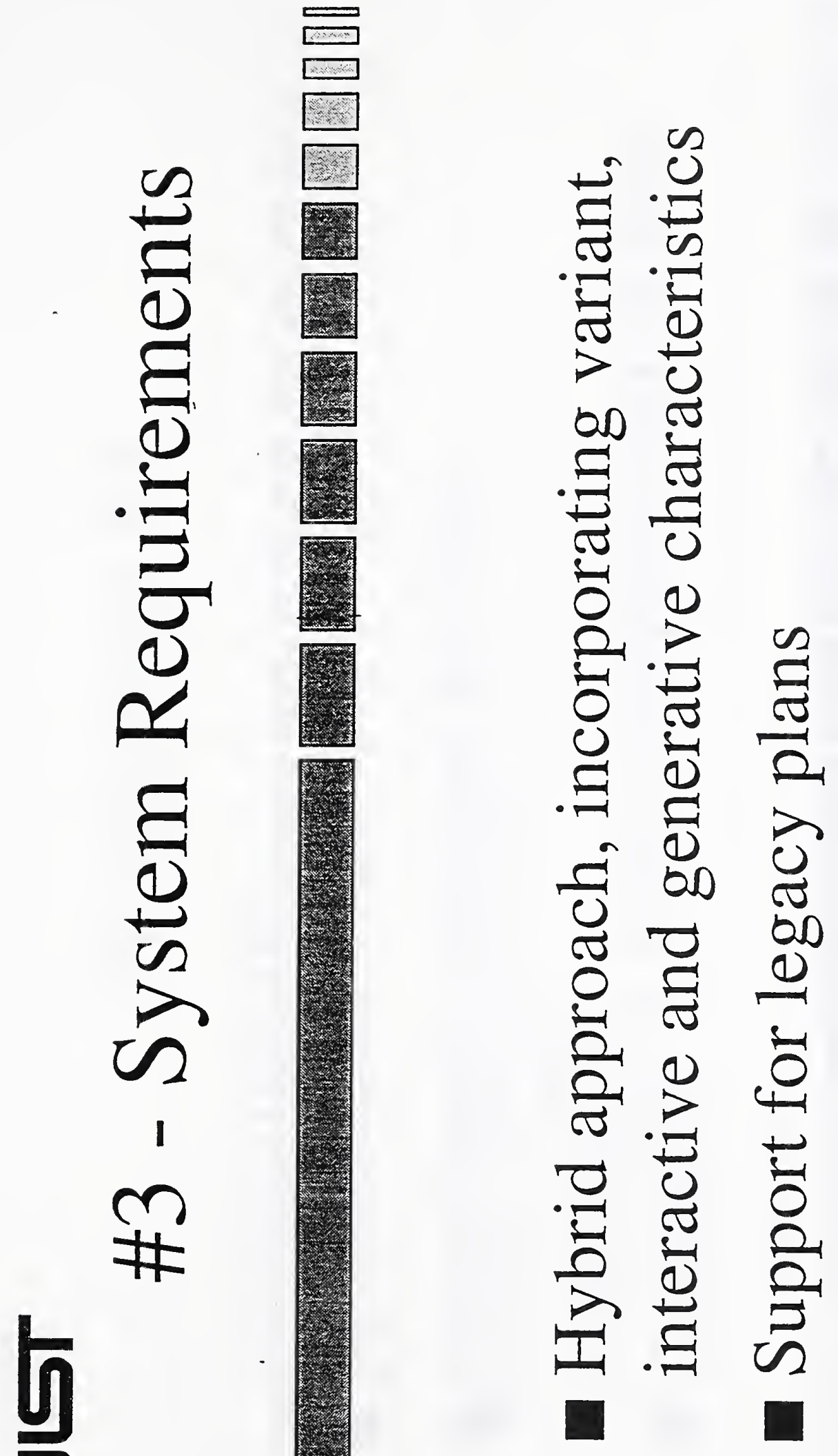




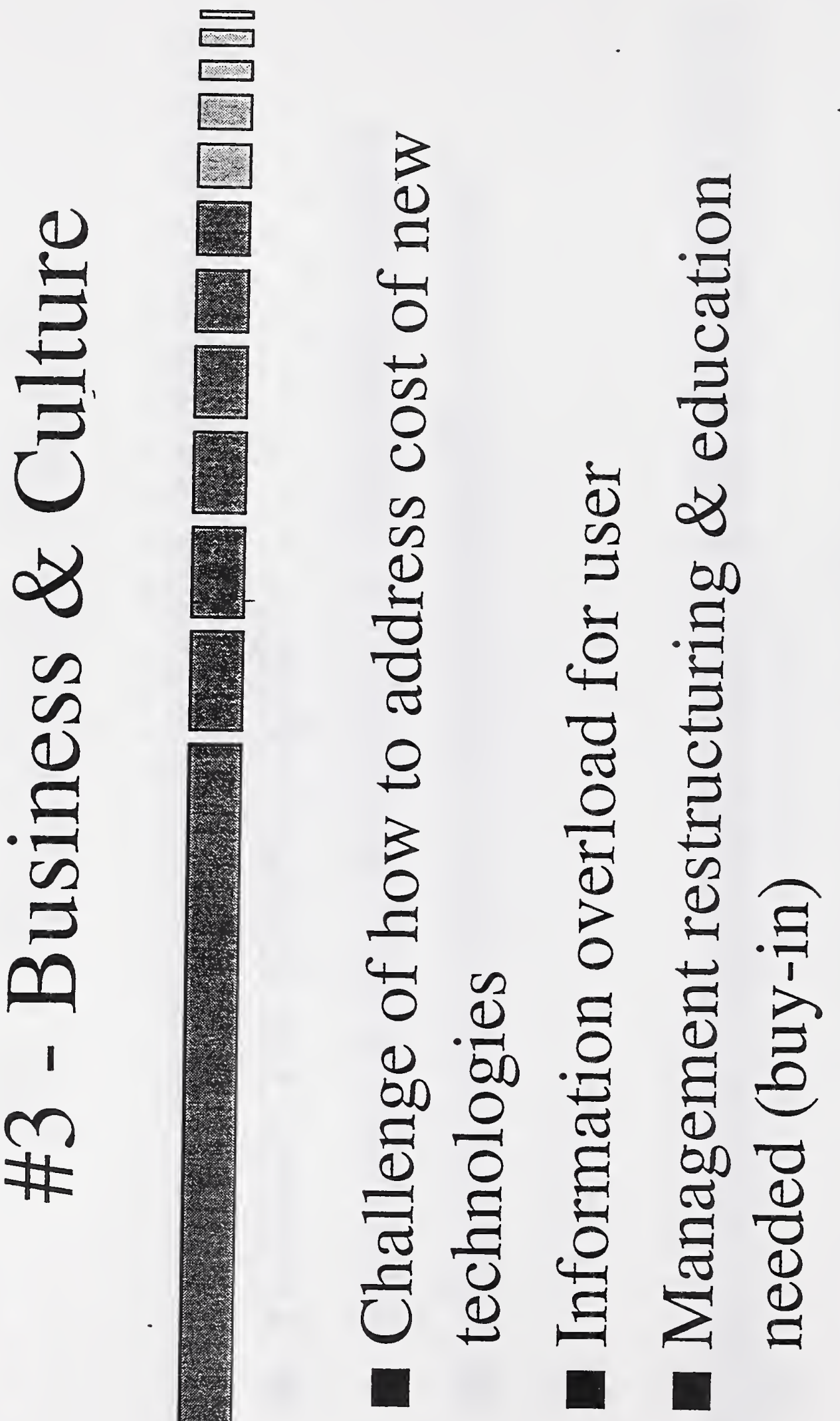




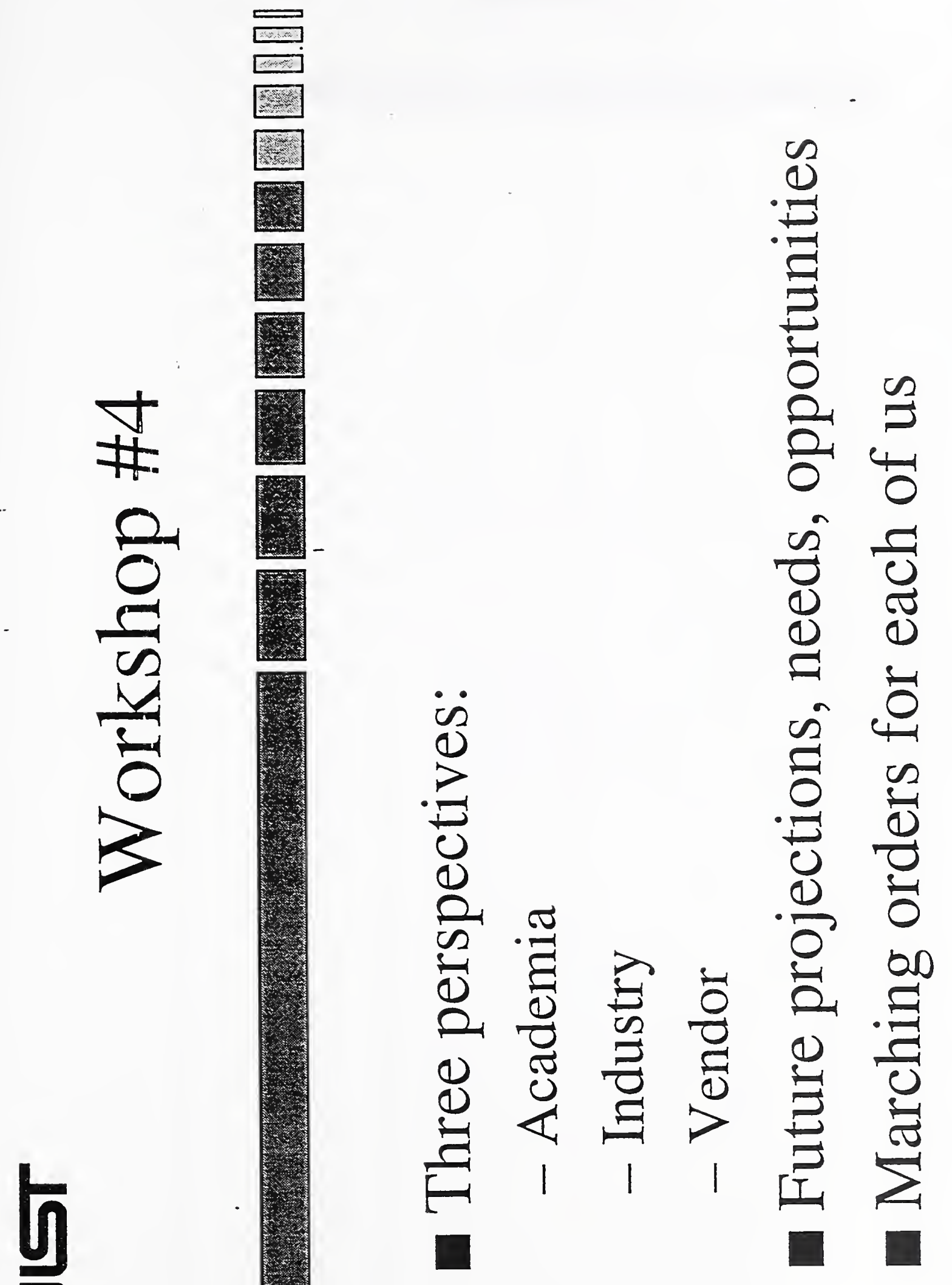





\section{Appendix C3}

Process Planning: Capturing the Imagination 

Process Planning: Capturing the Imagination

David Bourne

Senior Scientist

Carnegie Mellon University

Robotics Institute 



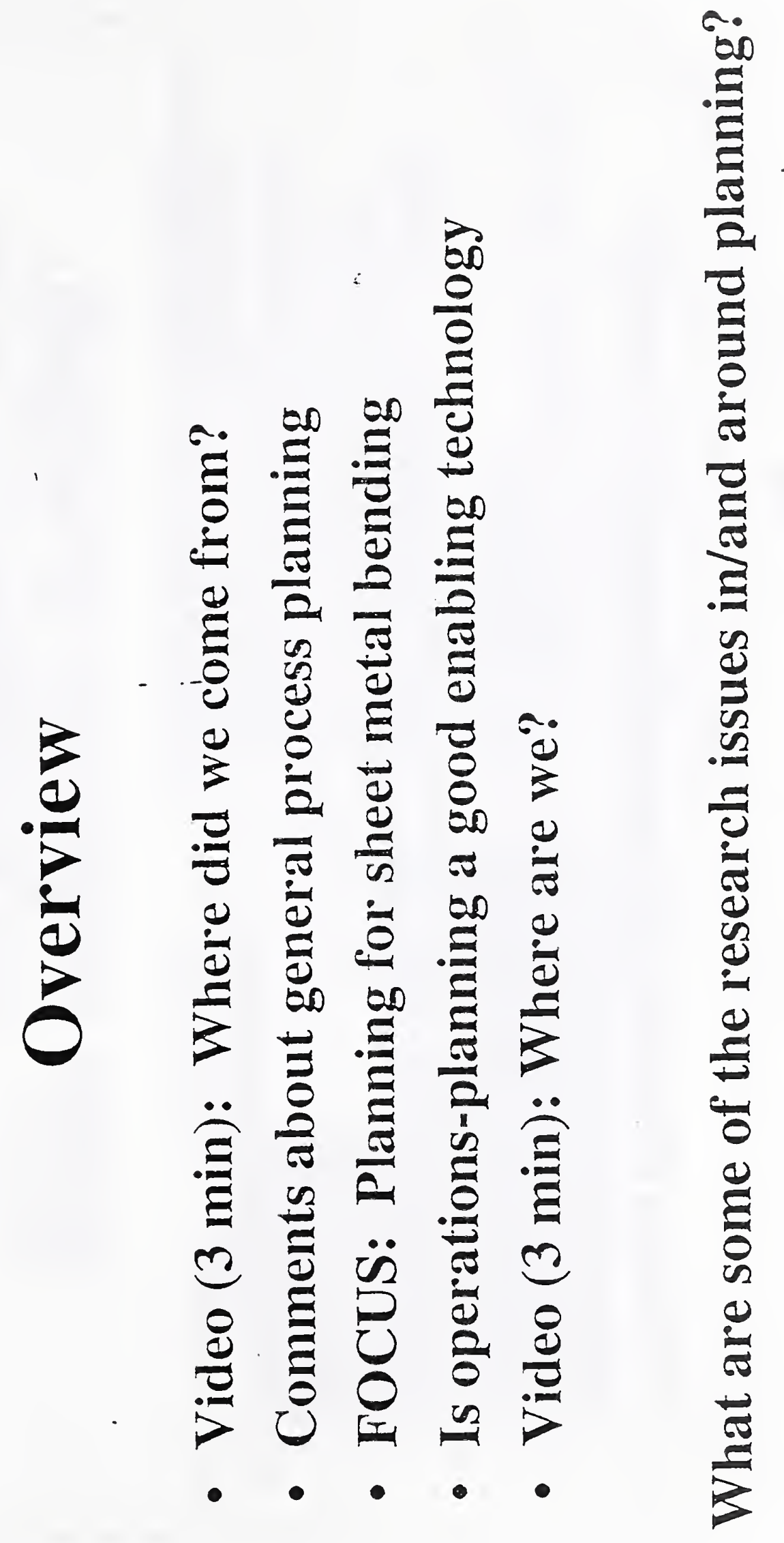




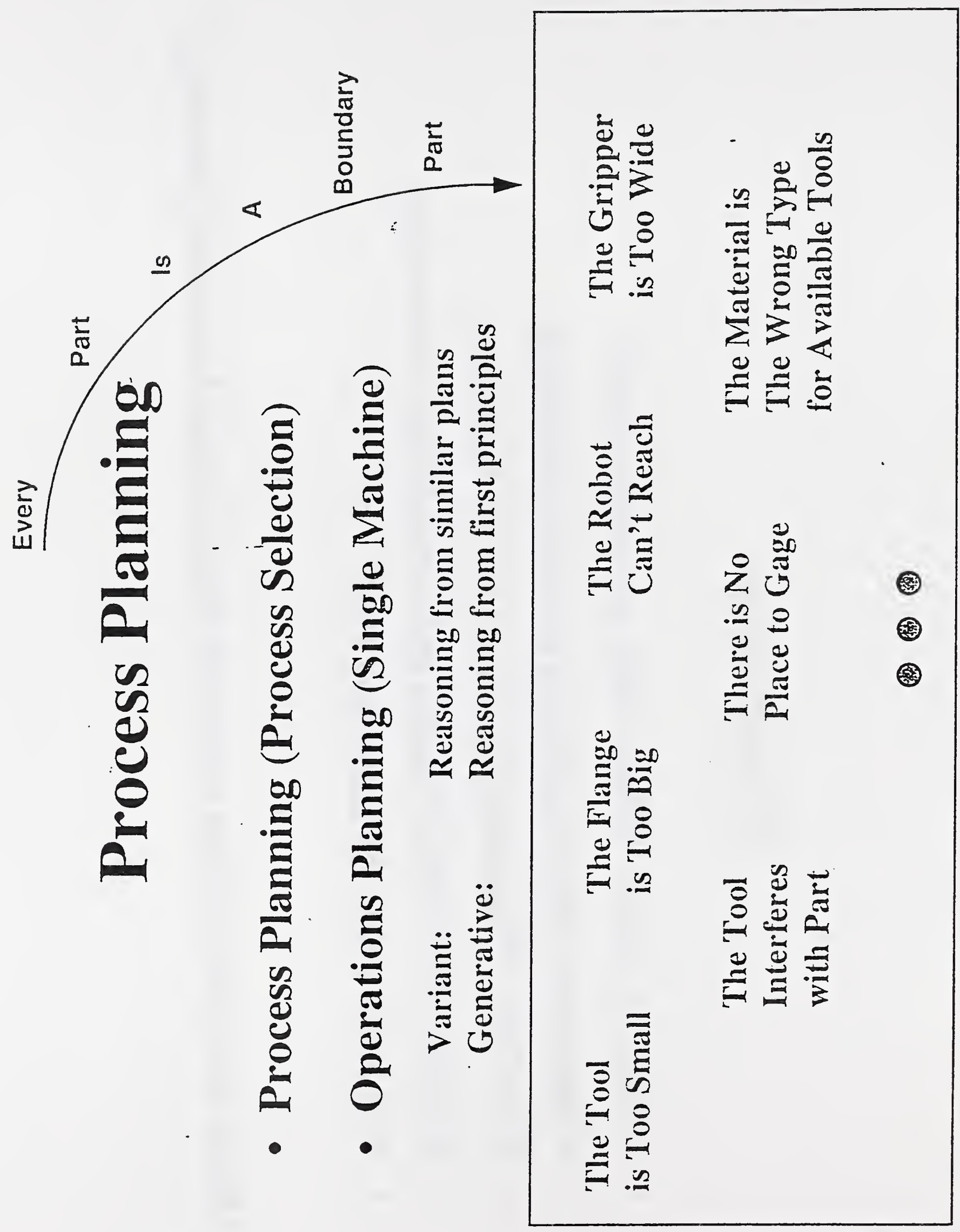




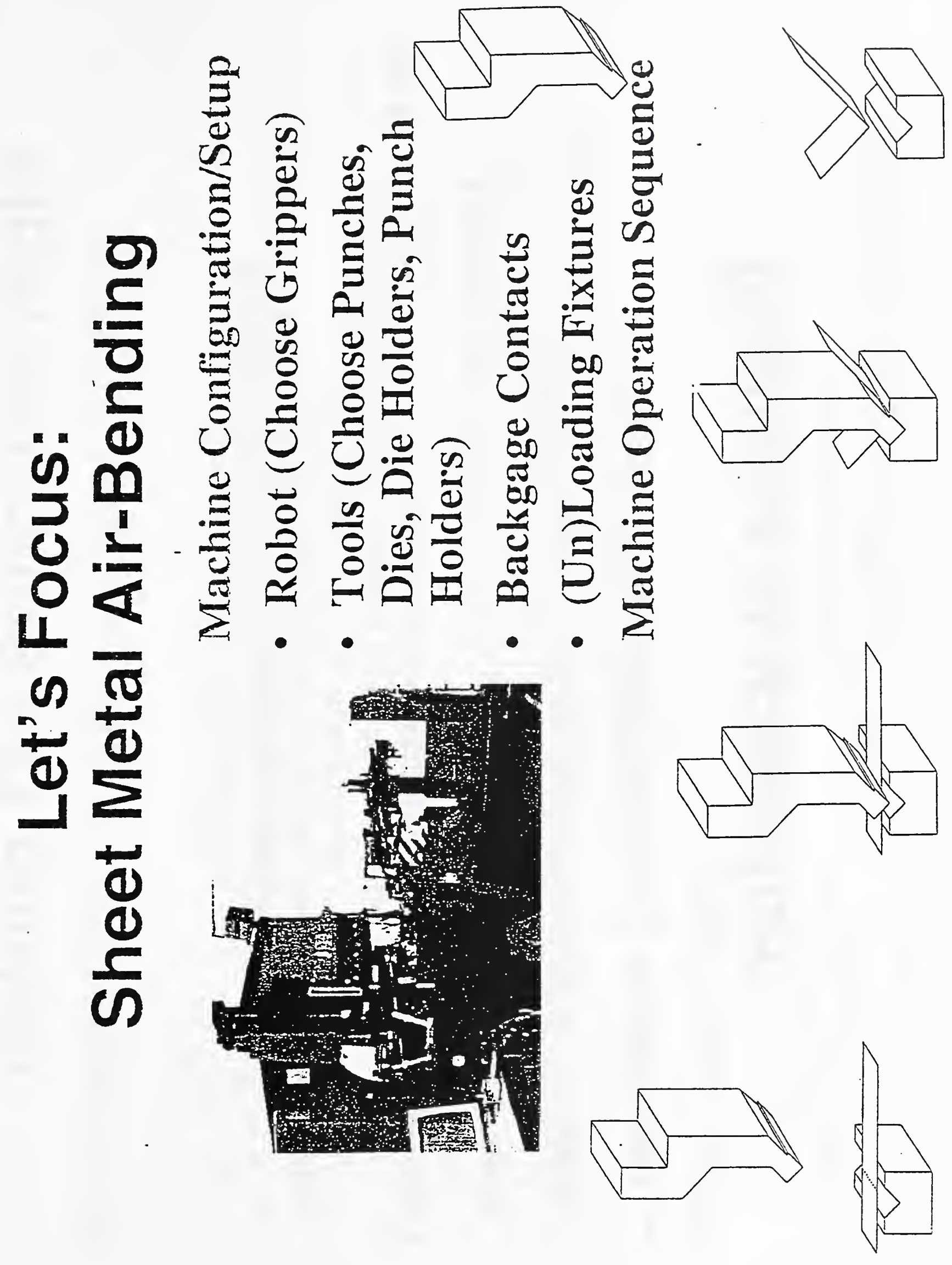




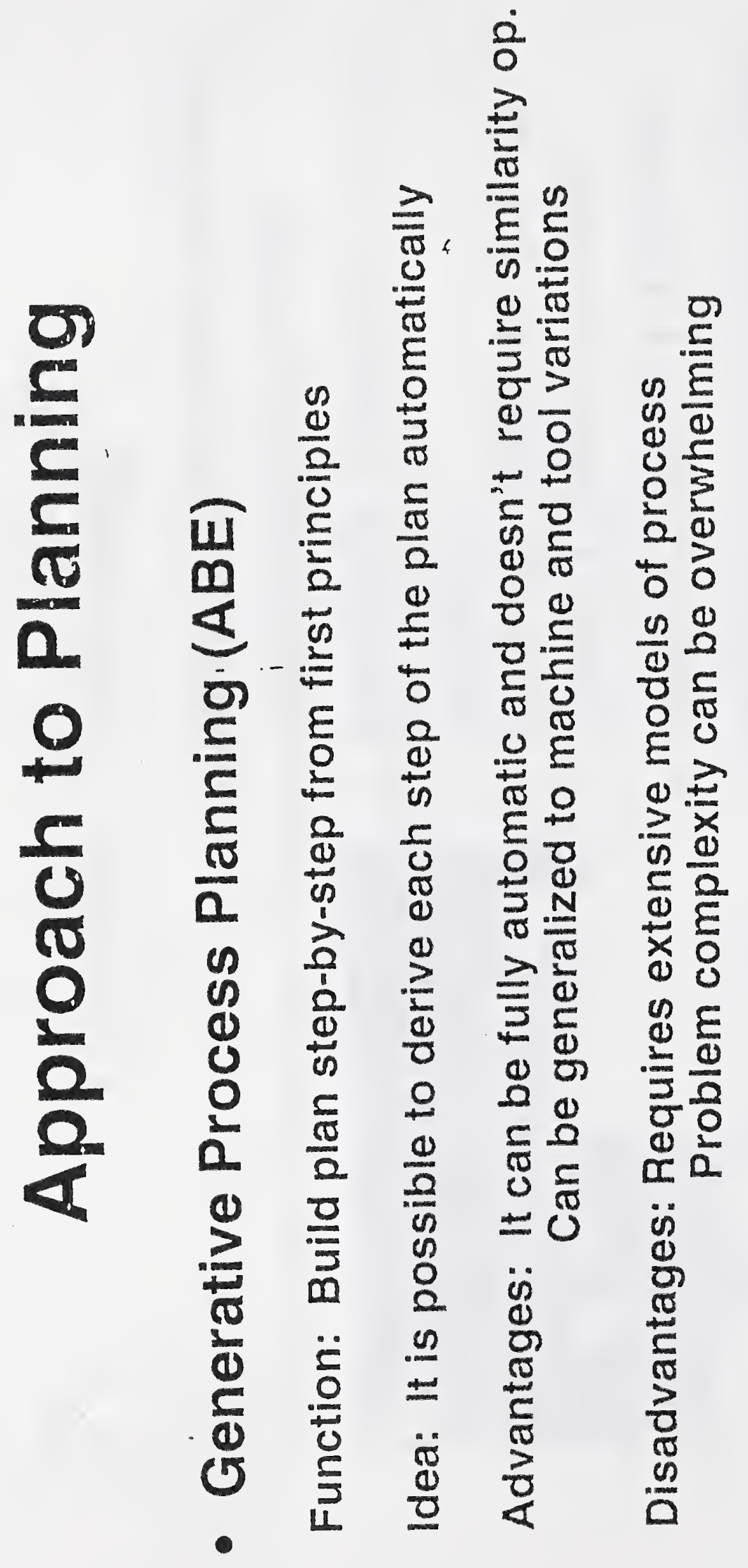




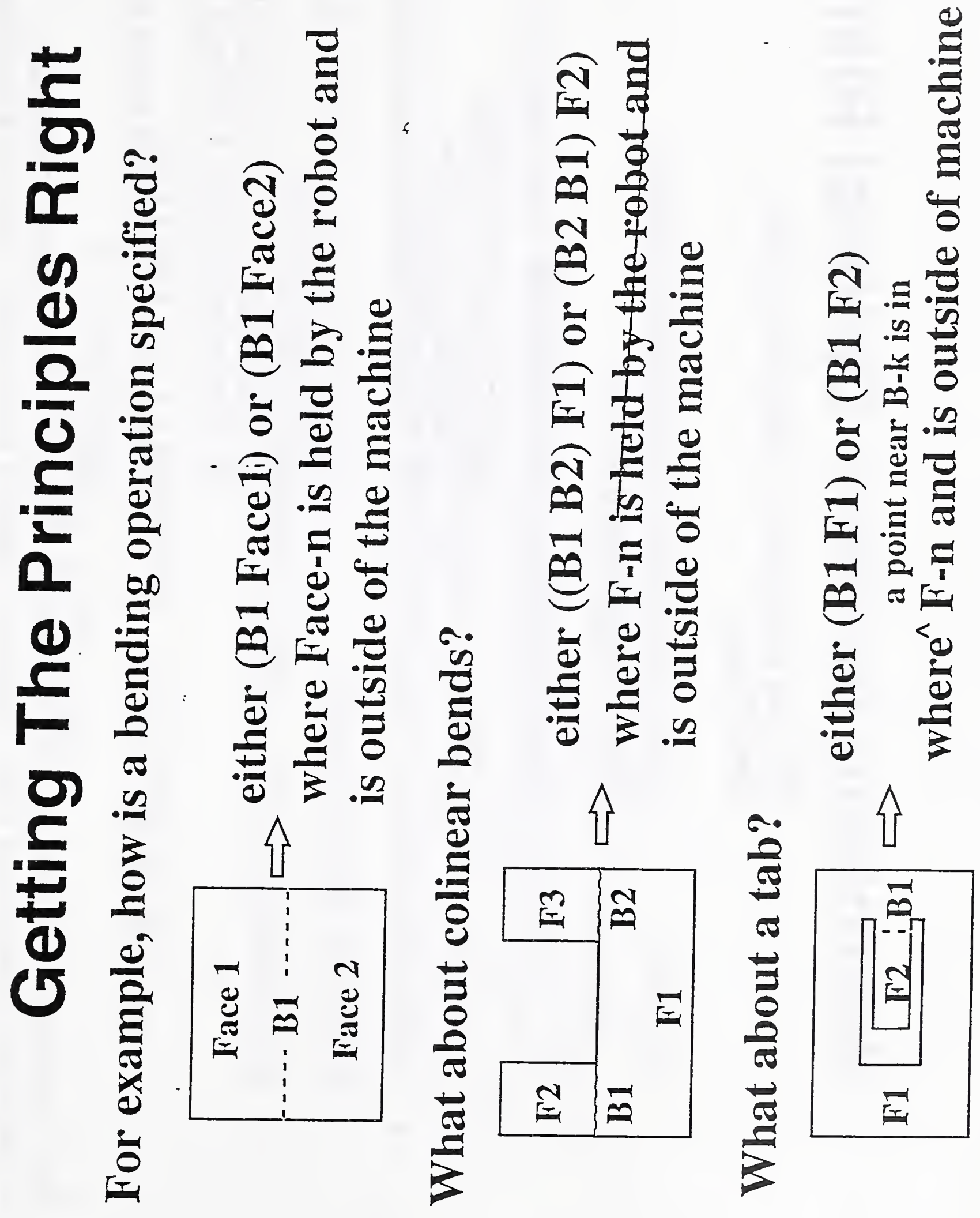




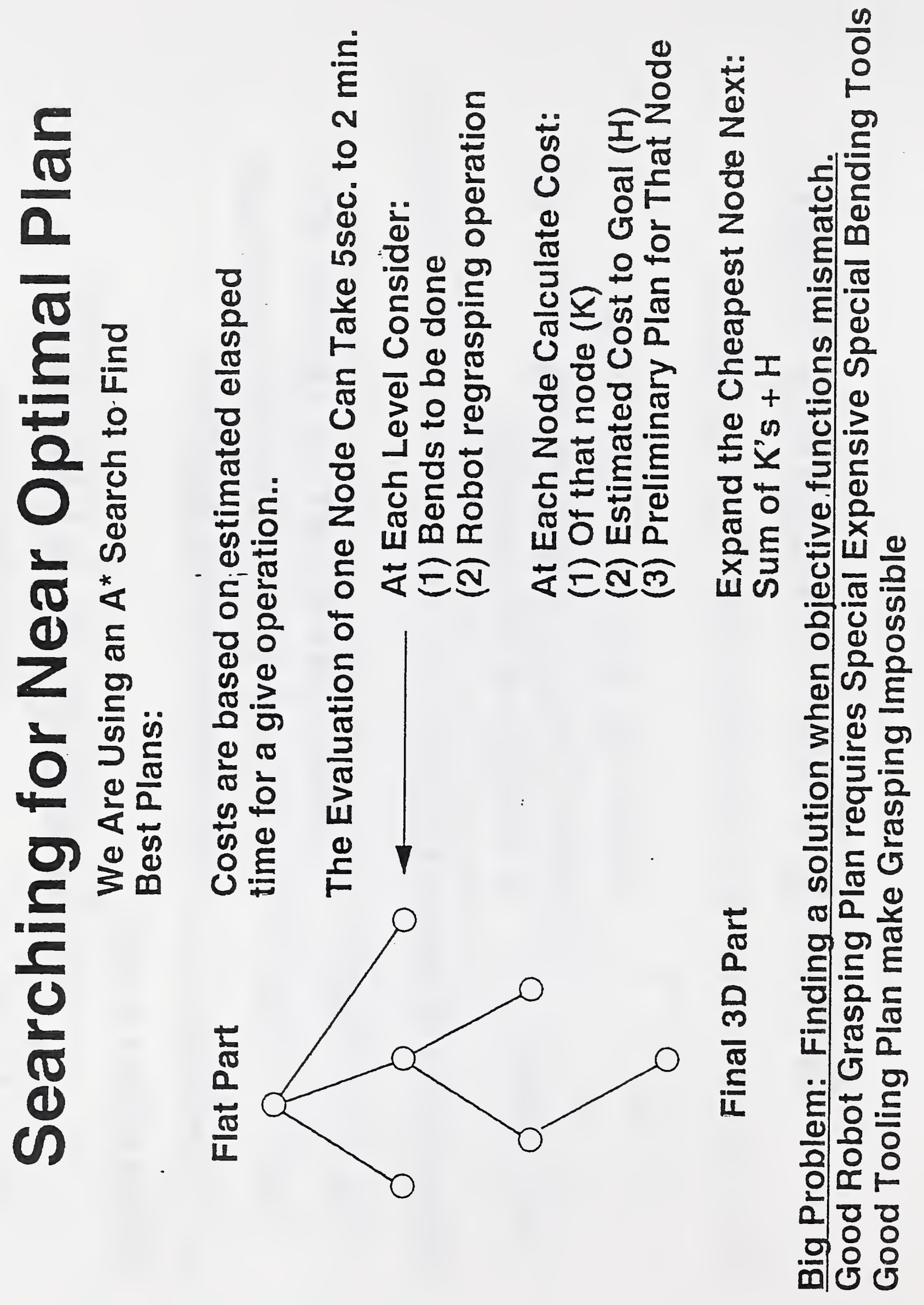




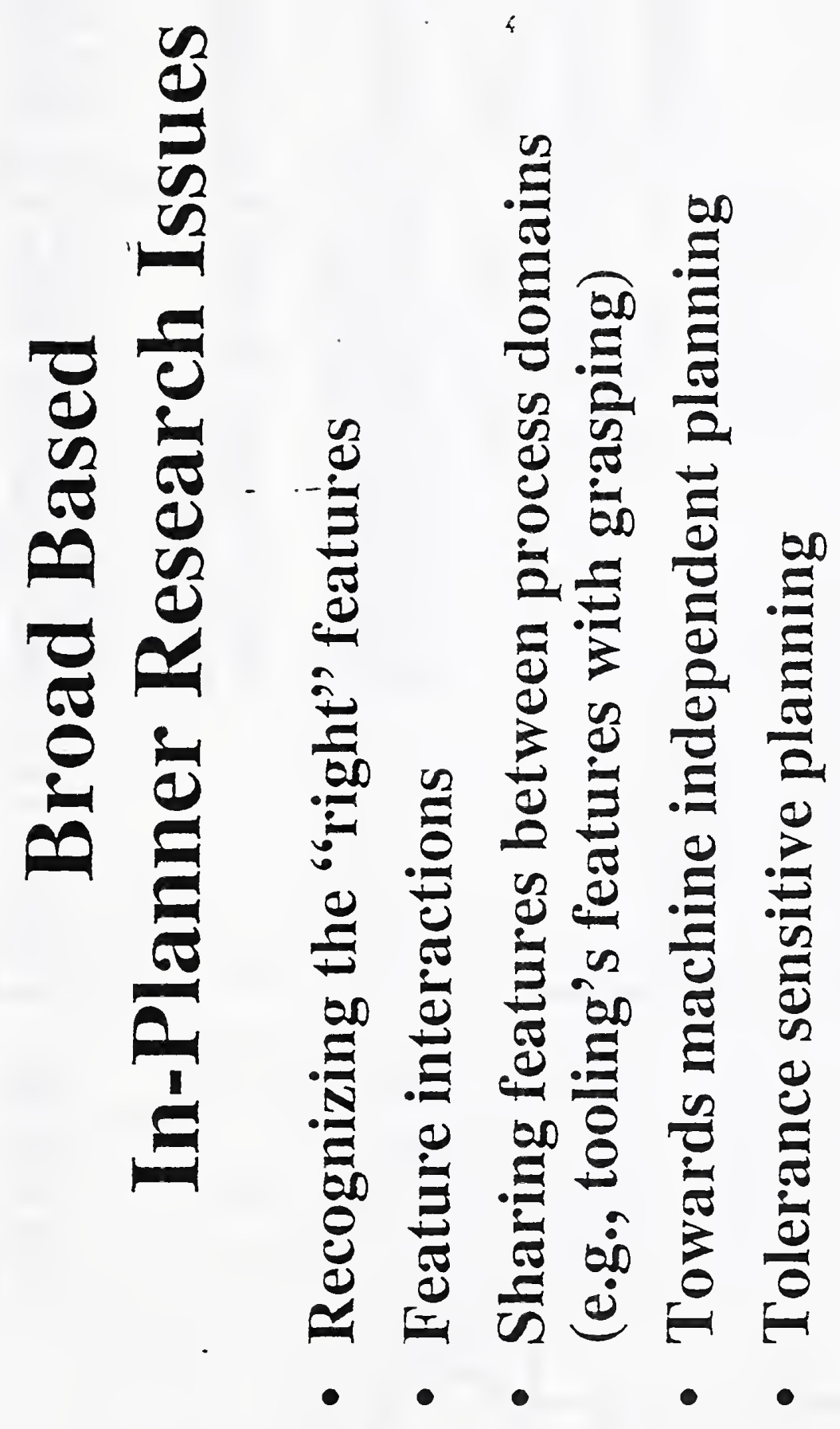




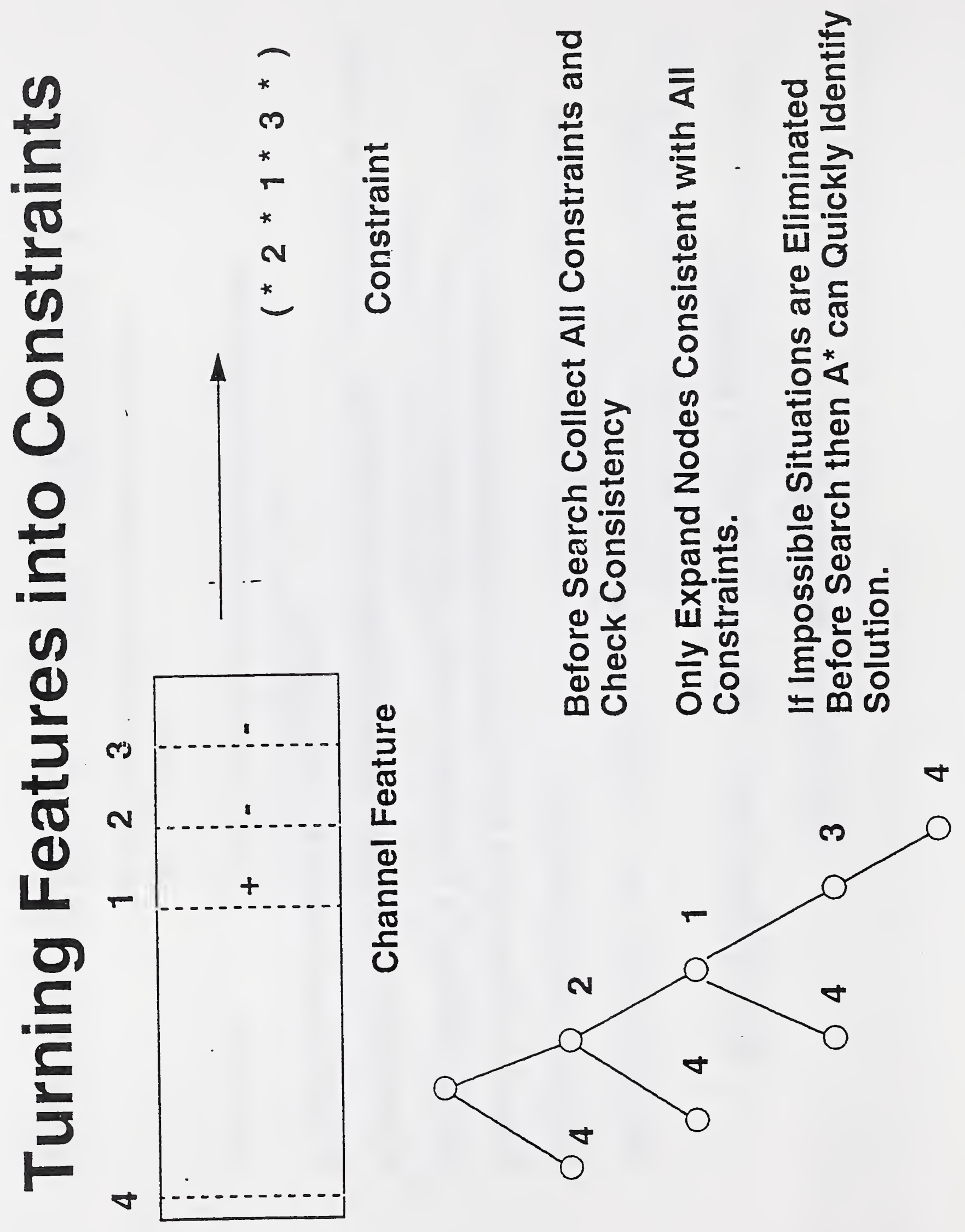



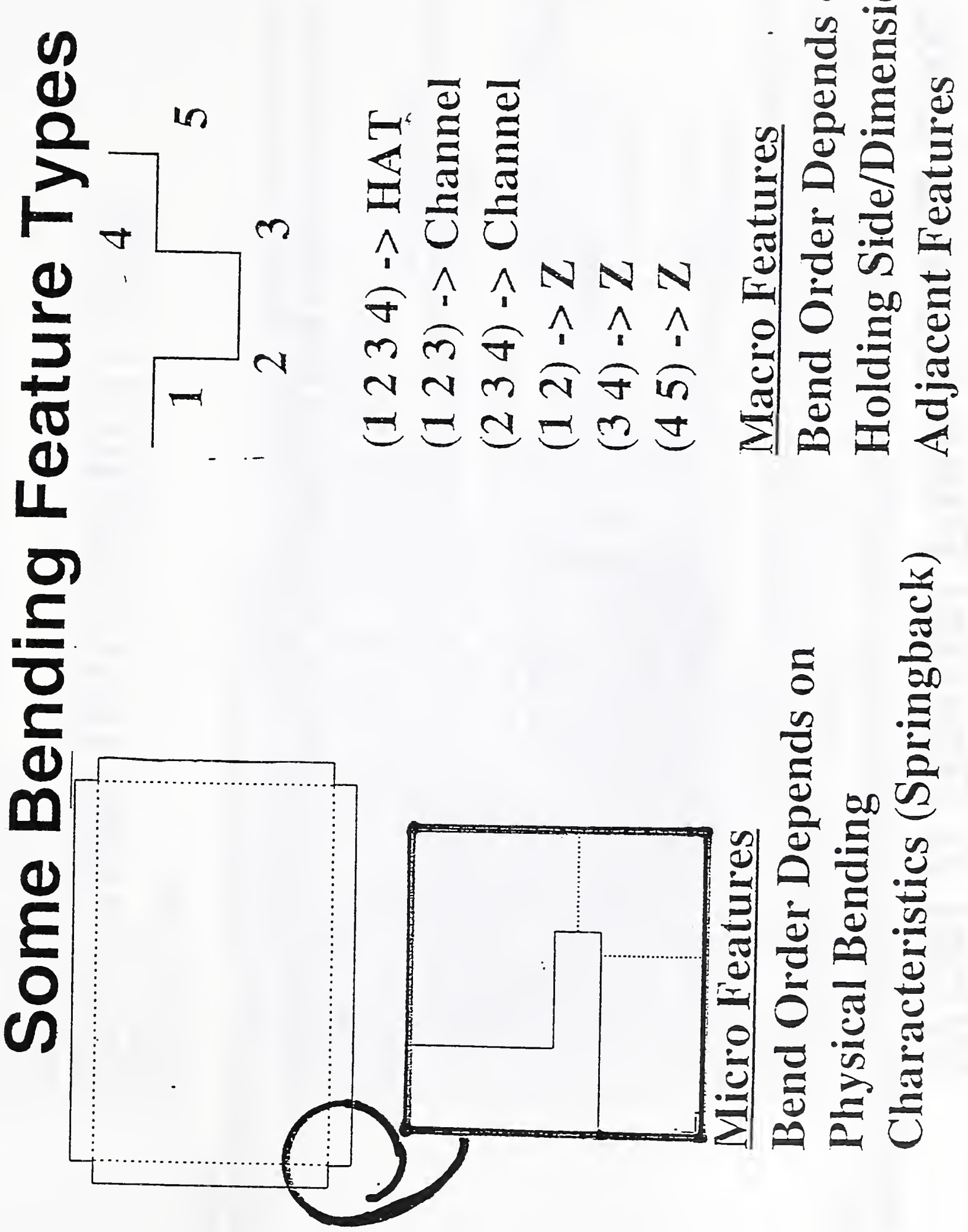


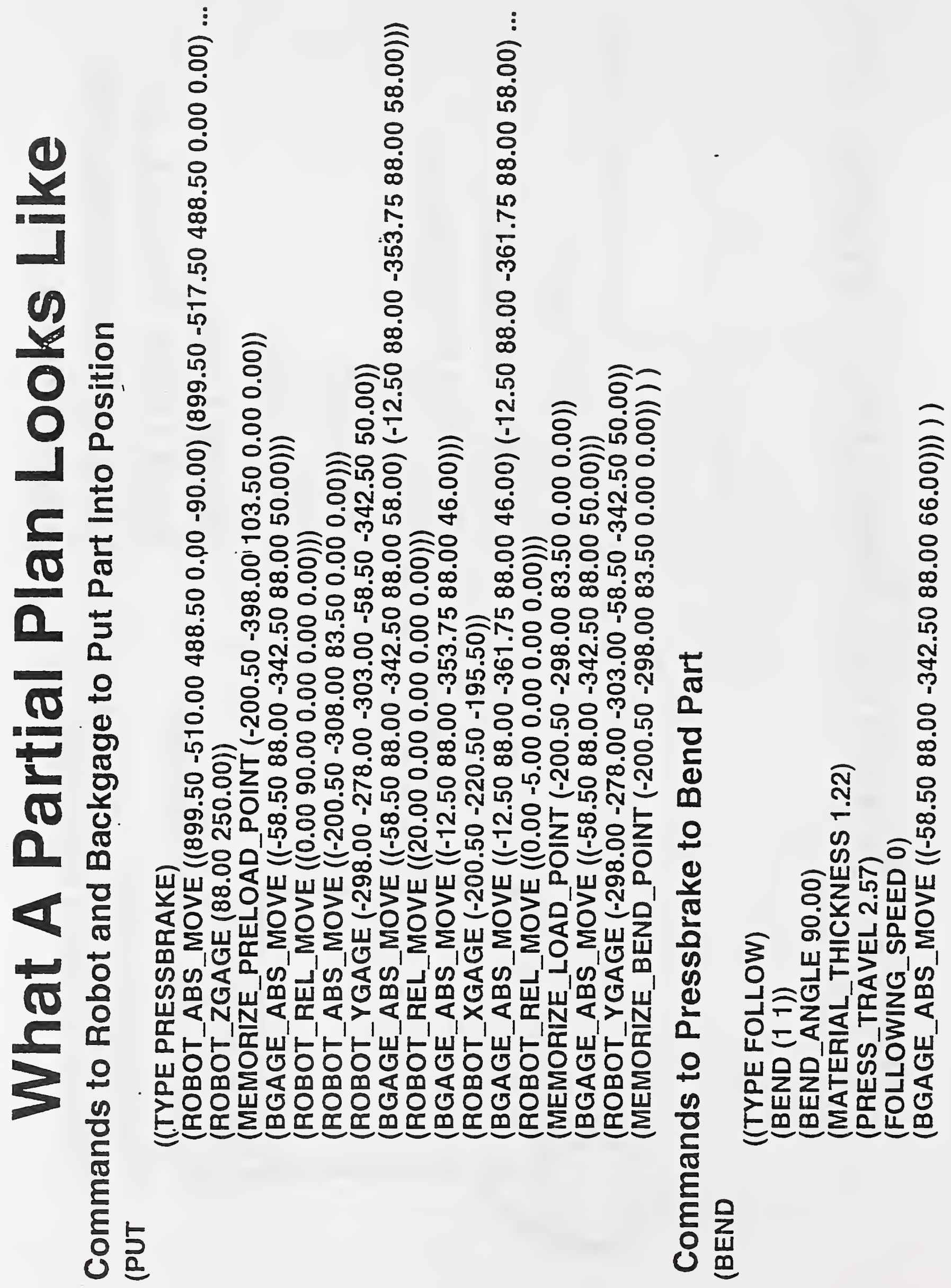




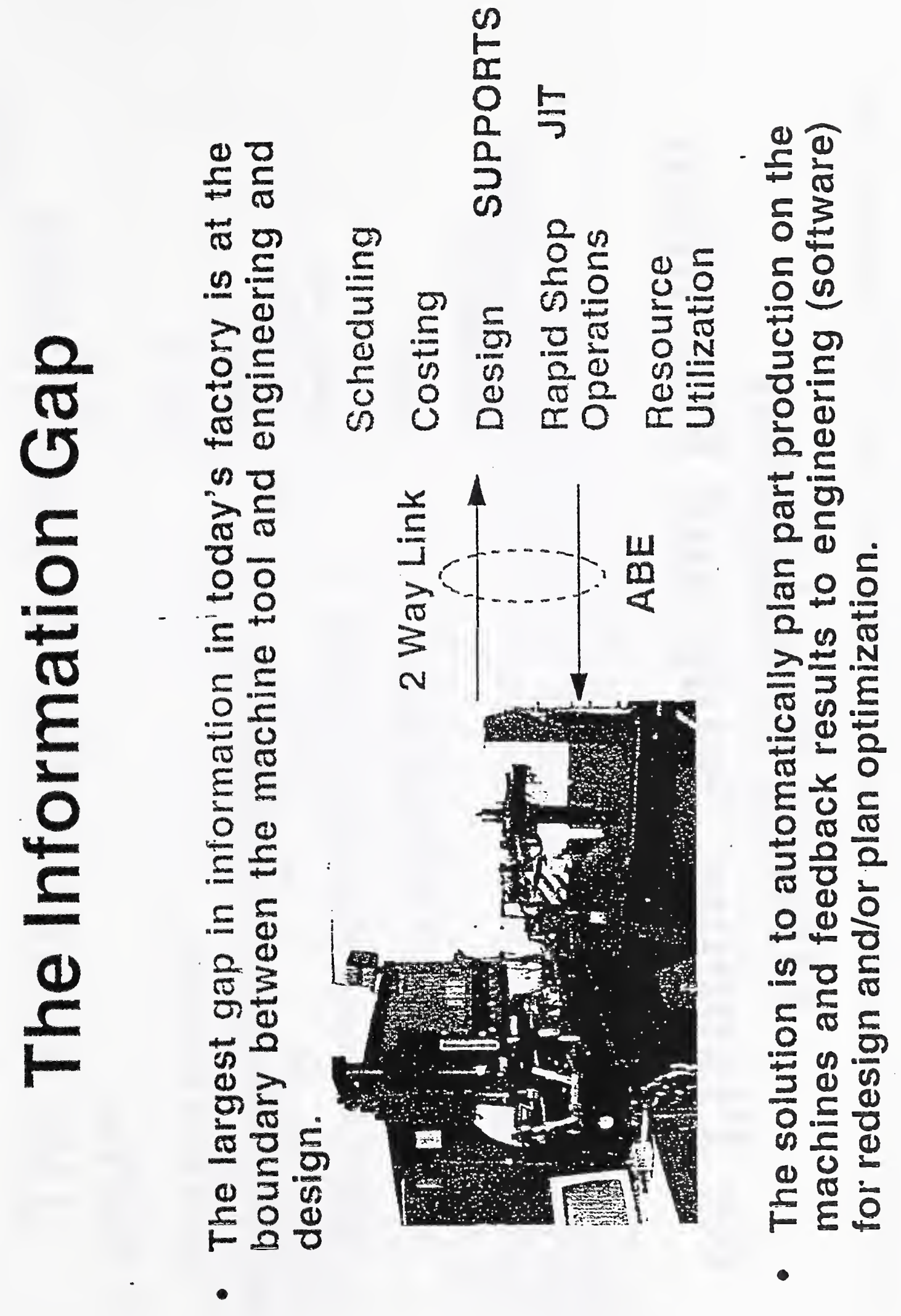




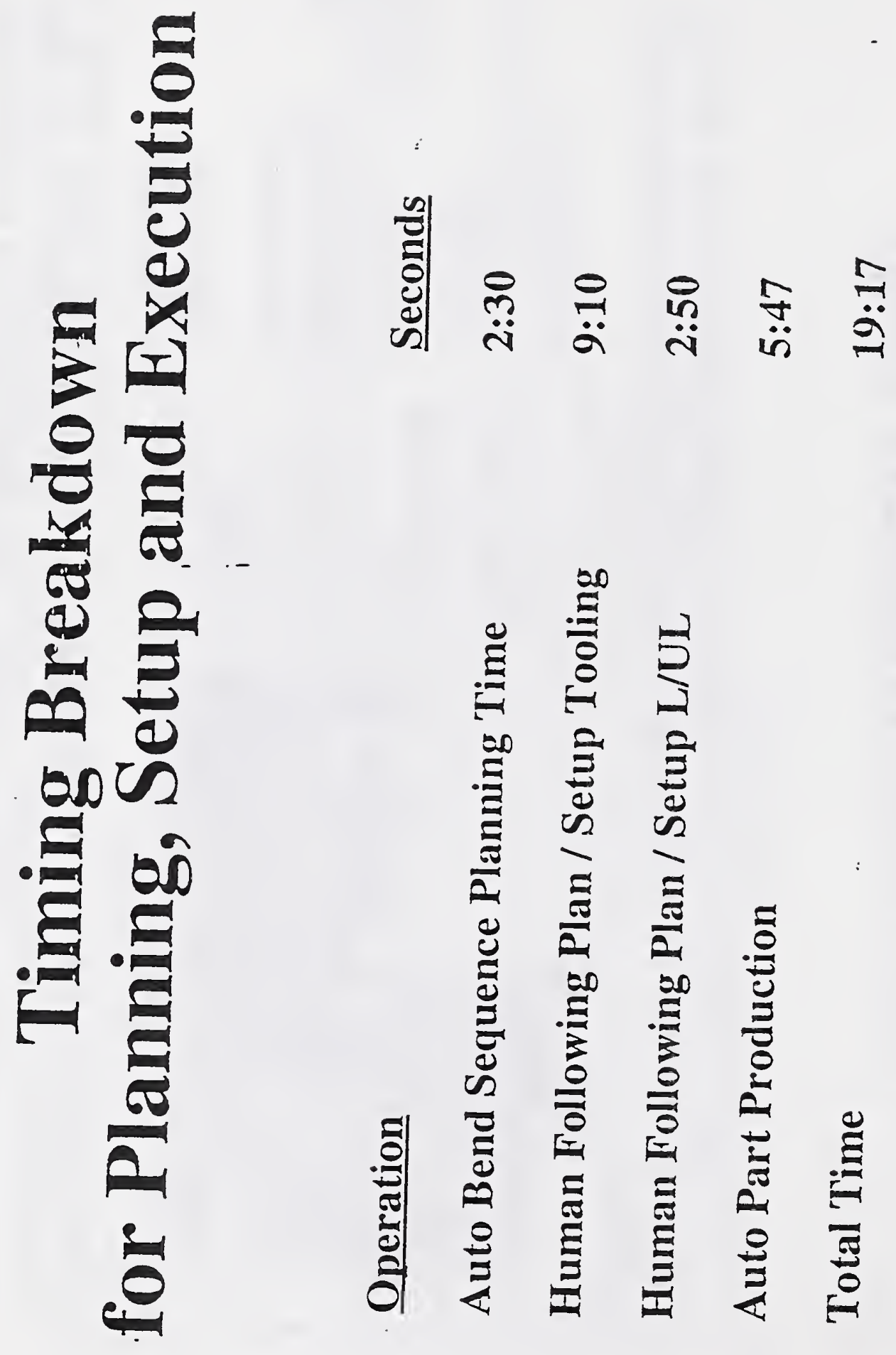


吾

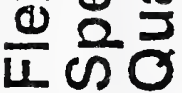

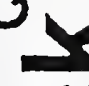

0

(0)

0

0

d)

0

4

$\geq \frac{9}{5} \frac{\pi}{0}$

을

这出岕

。

()

O)

(1)

$+$

$\frac{E}{2}$

()

$E$

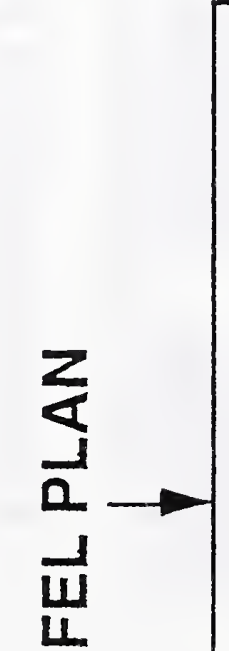

ลี

0

ल

$+$

لृّ

立. 근 $\frac{1}{0}$

는믐

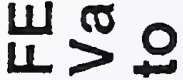

o

()

N

tั

ডั๊

น

क

ह

节

E

(a)

o

흔

ह

(1)

$\stackrel{\underline{E}}{\underline{E}}$

흠ำ 


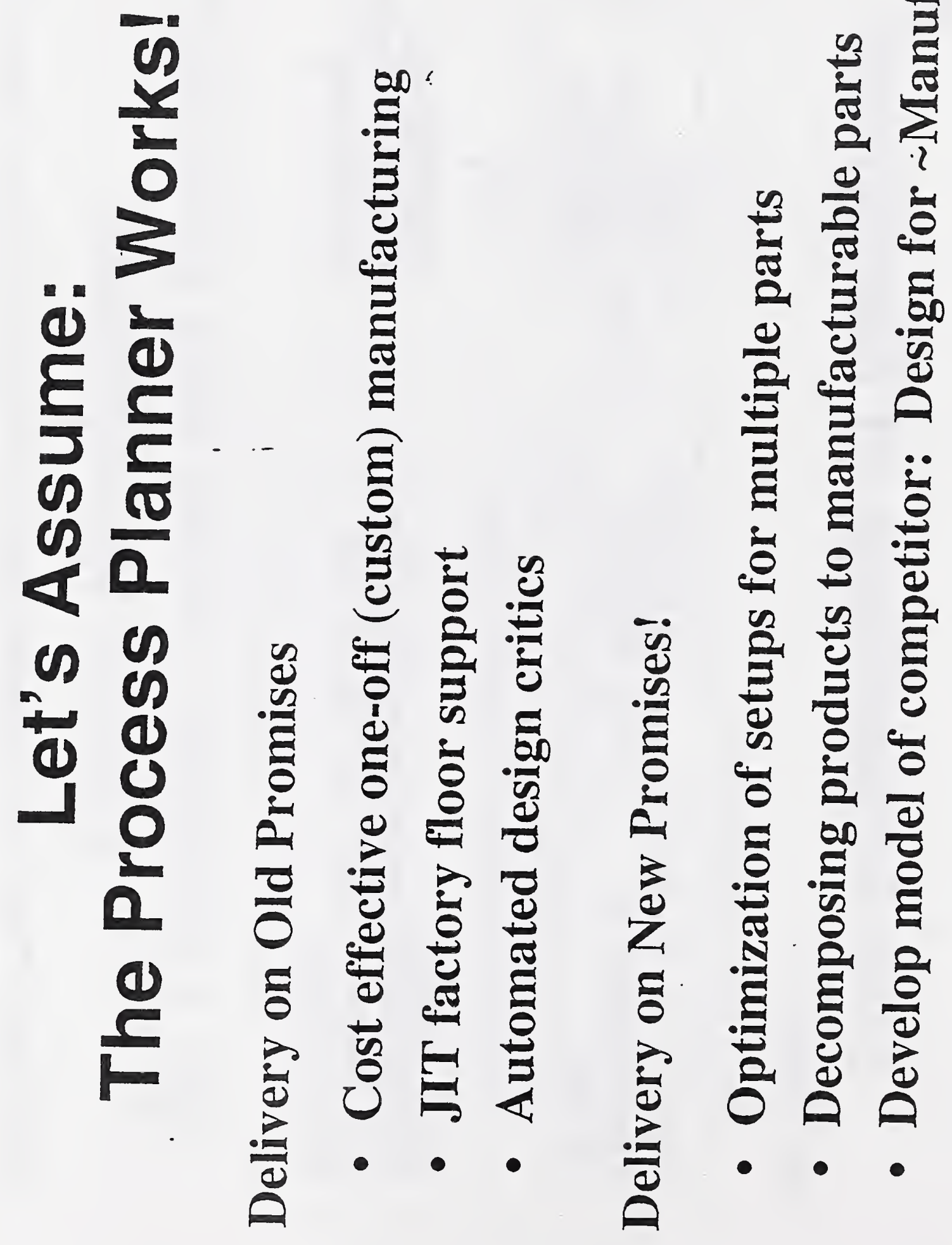



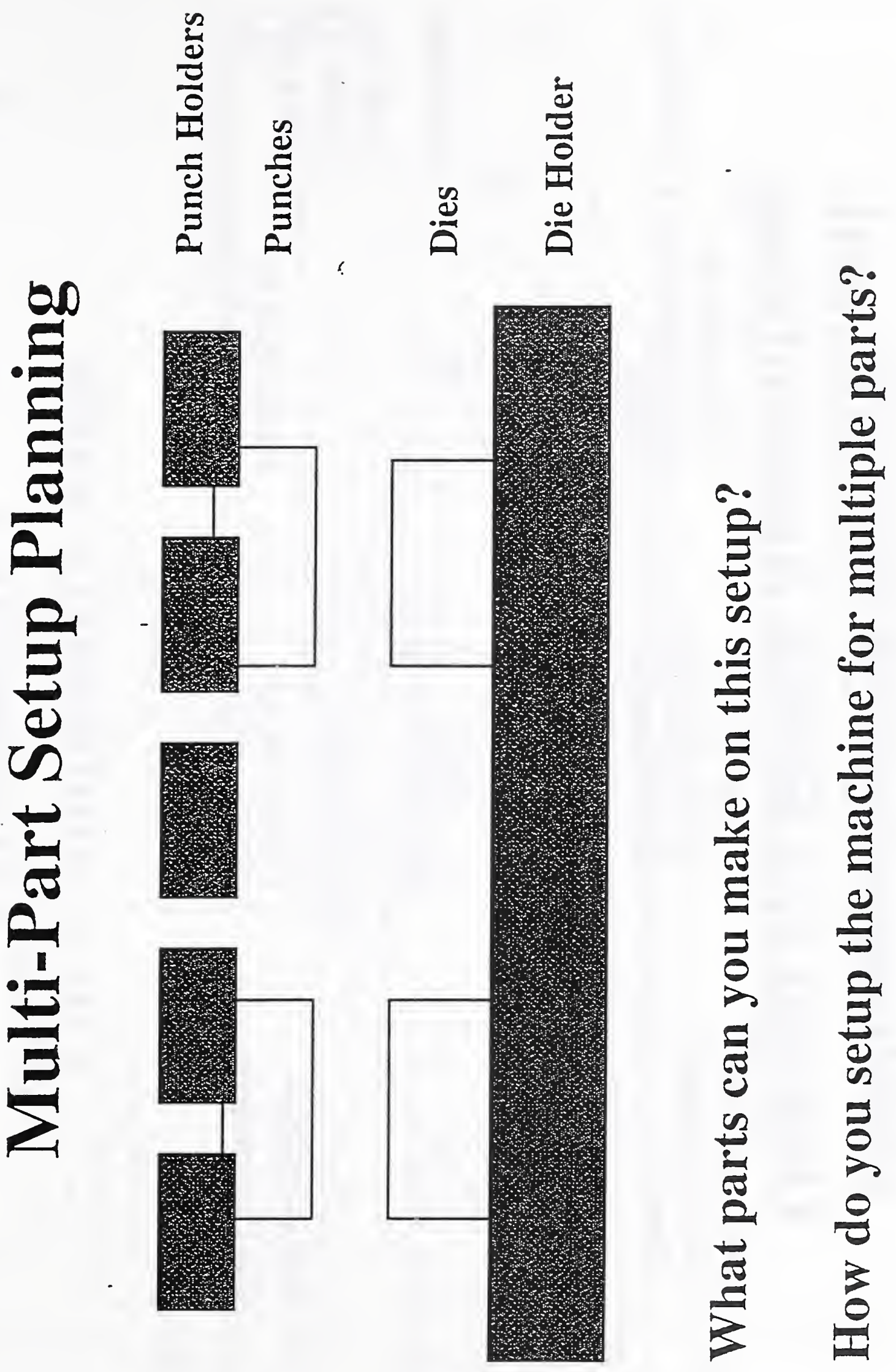


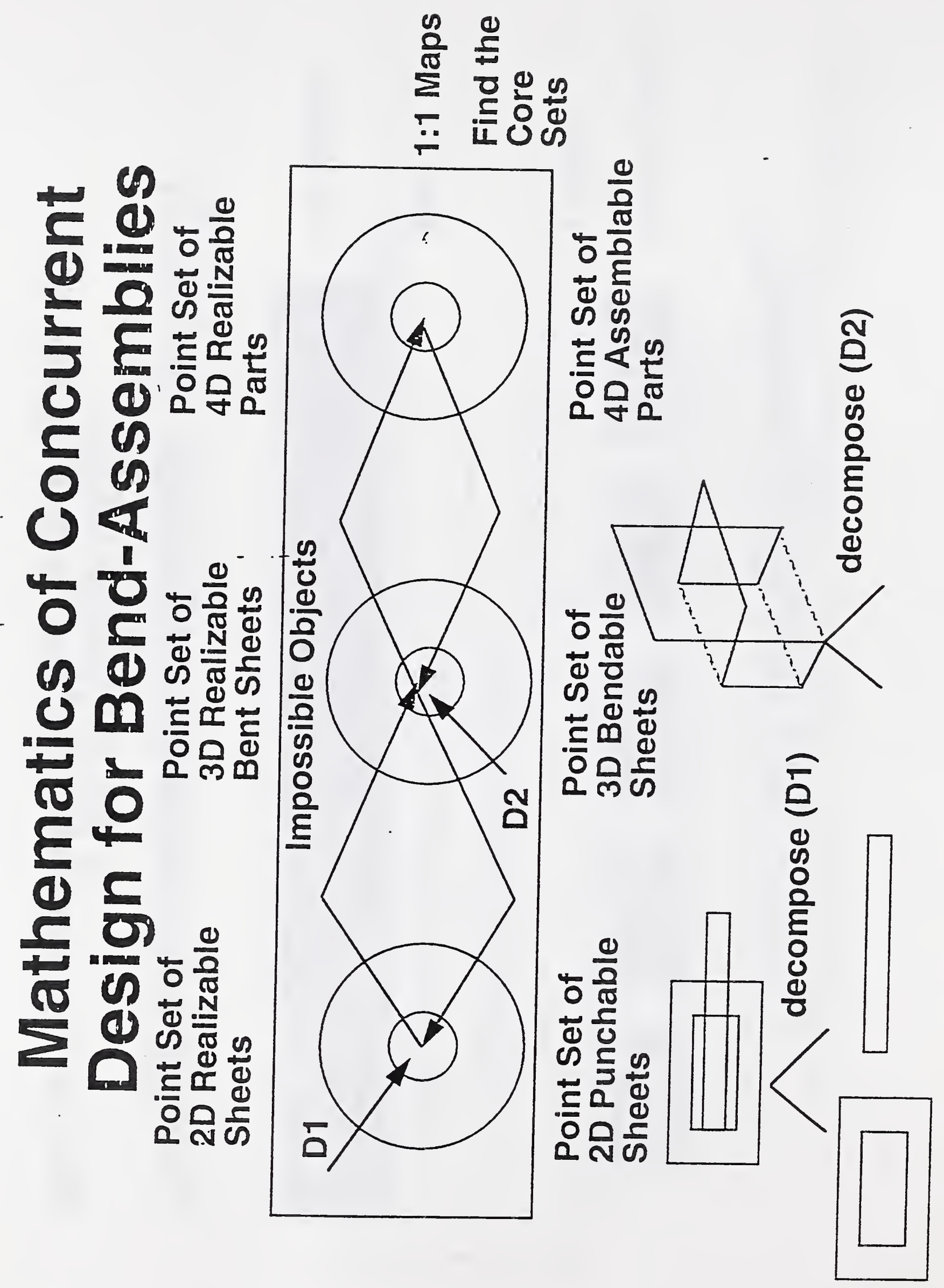



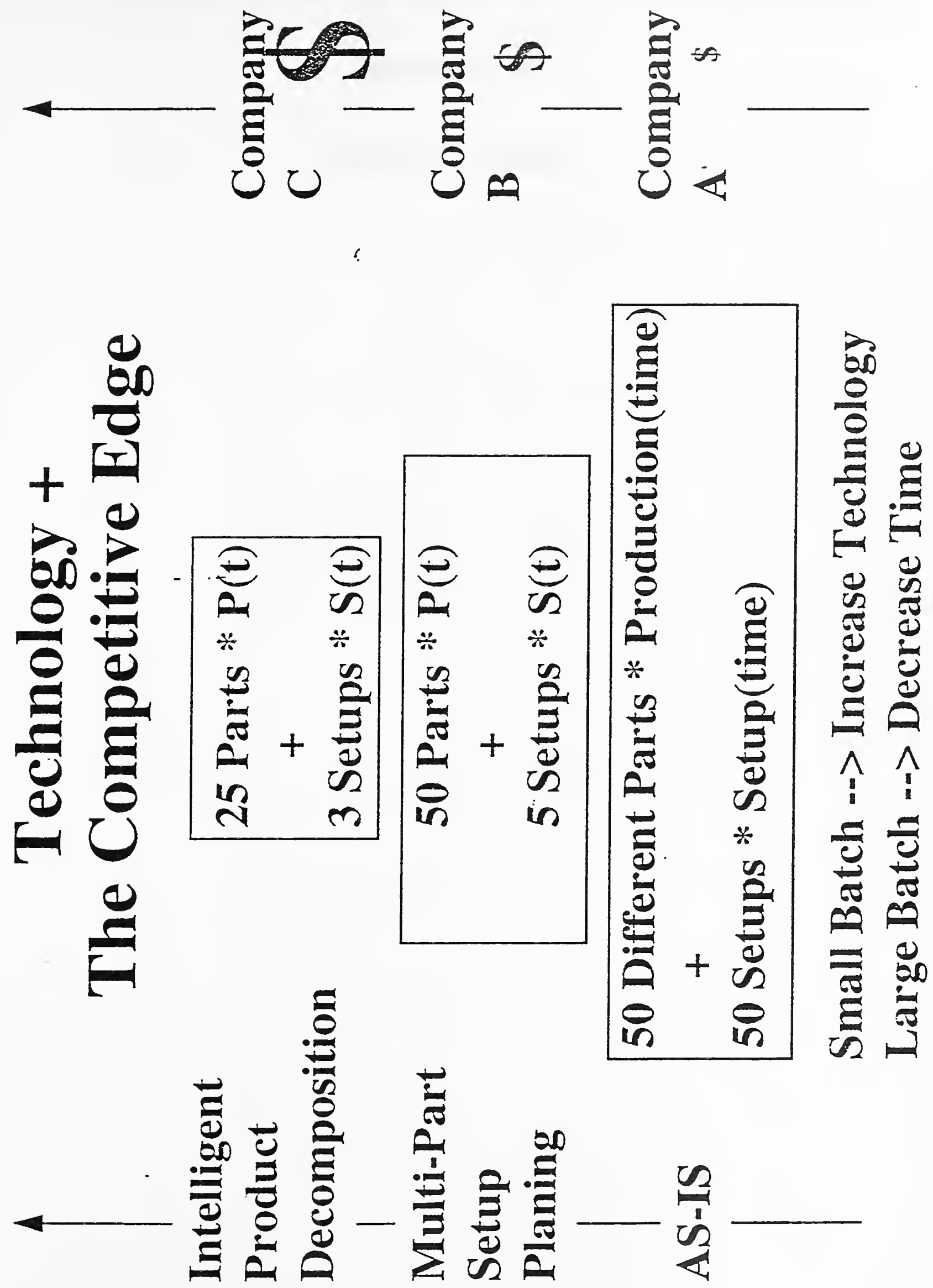



\title{
Appendix C4
}

\author{
Mechanical Space
}





\title{
MechanicalSpace
}

\author{
Peter Brooks \\ Director, Mechanical Products \\ Bentley
}

NIST Process Planning/CAME

Conference

Bentley in Mechanical Engineering

- Daratech 1996 projection: \#11 CAD/CAM/CAE company worldwide

- MCAD in 1995

- $\$ 14$ Million

- 33,000 MCAD users world wide

- MicroStation product growth rate: Highest in the industry 


\section{Translation-based Workflow .}

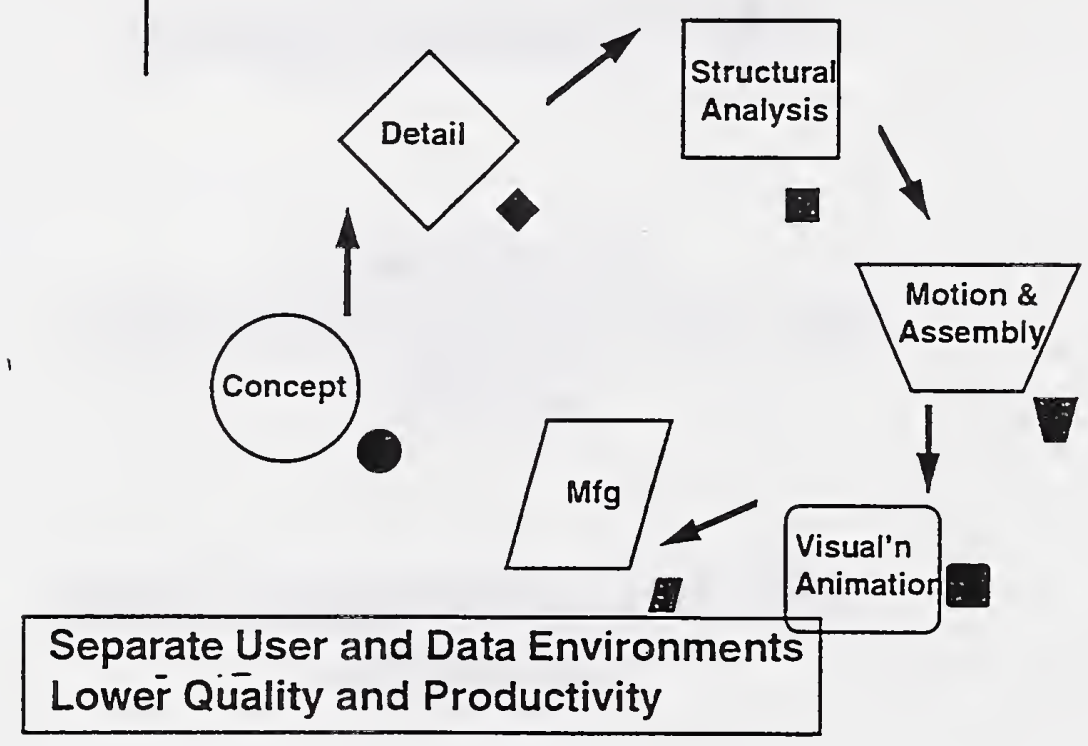

Single Engineering Model Workflow
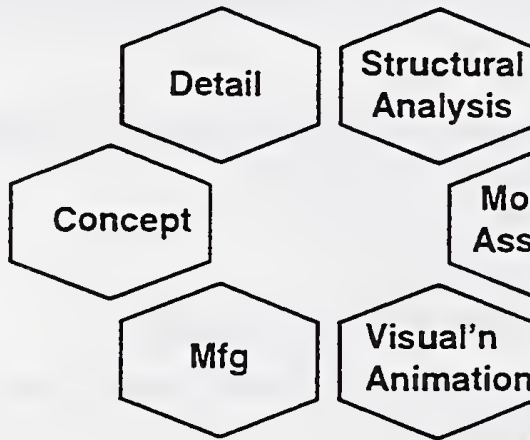

Analysis

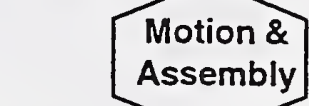

Single User and Data Environment

Higher Quality and Productivity 


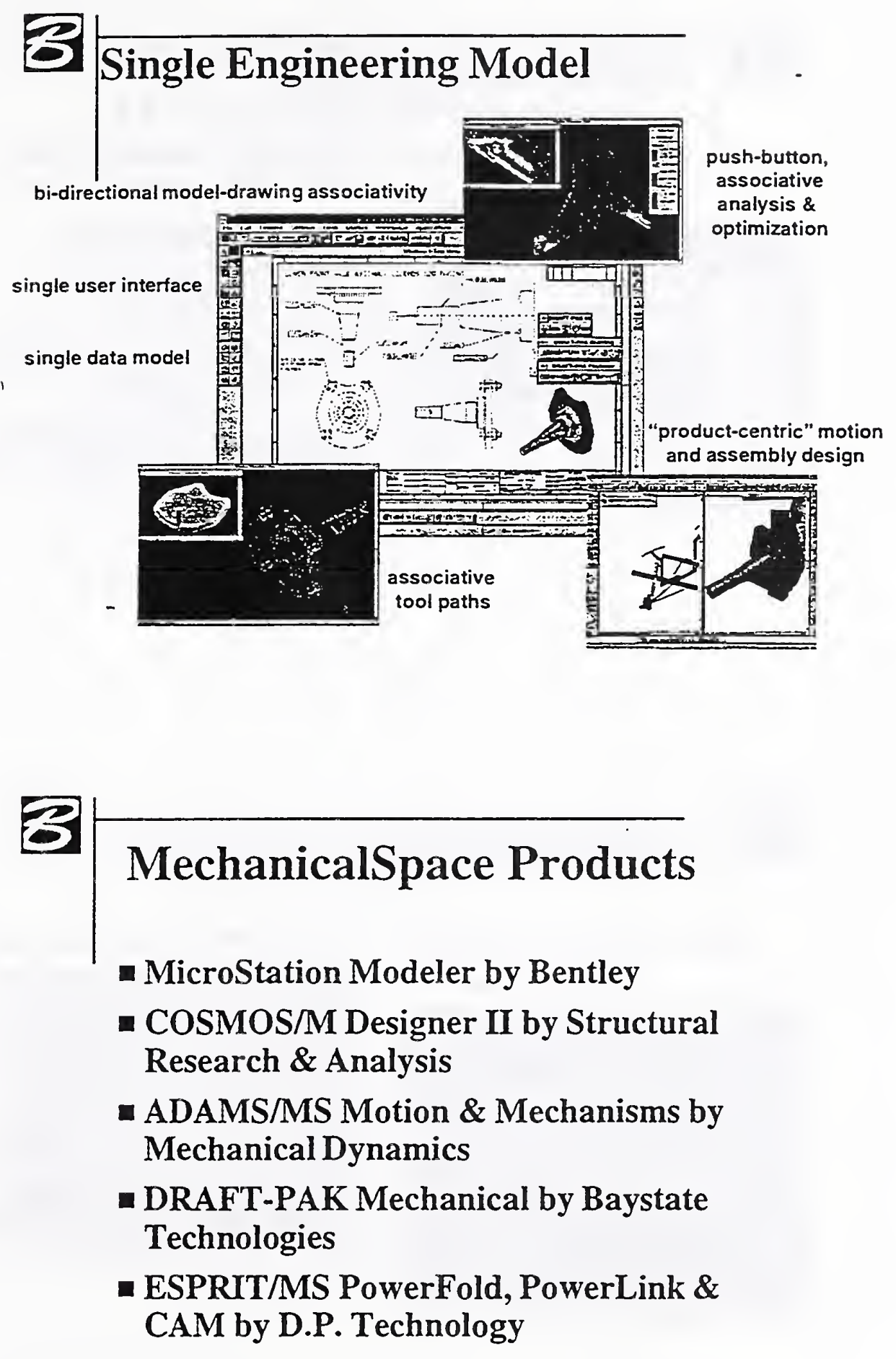




\section{MicroStation Modeler}

- Integrated 3D assembly, solid, surface, wireframe modeling

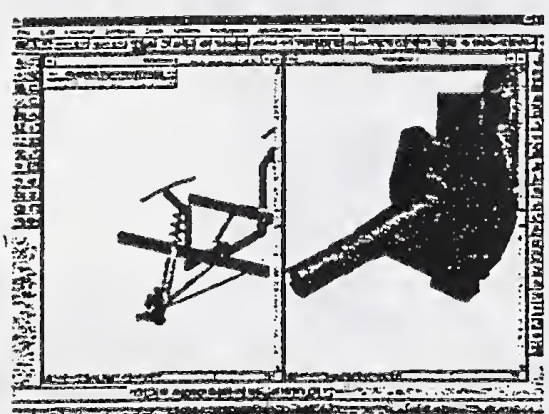

- Hybrid CSG and B-Rep

- Parametric, variational and feature-based design

- Associative mechanical drafting

- DOS, Windows, UNIX

- Open environment: STEP, IGES, ACIS, OLE, DWG, DGN, CGM, $\mathrm{MDL}$

\section{COSMOS/M DESIGNER II}

- Integrated design and analysis

- Automatic meshing

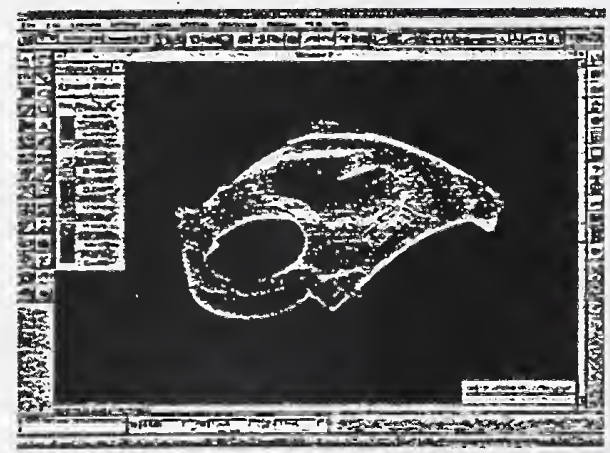

- Associative loads

- COSMOS/M, ANSYS, NASTRAN solvers

- Stress, dynamics, thermal, and fluids

- Integrated results visualization

- Structural Research distribution 
- Integrated design and analysis

- Motion

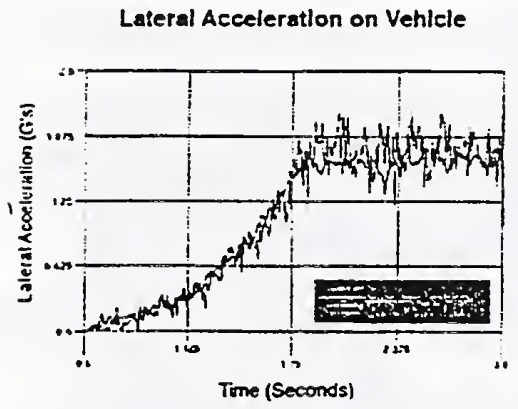

- Check motion paths

- Locate lock-up position, detect part interferences

- Create assembly motion

- Mechanisms

- Motion

- Calculate joint reaction forces

- Bentley distribution worldwide

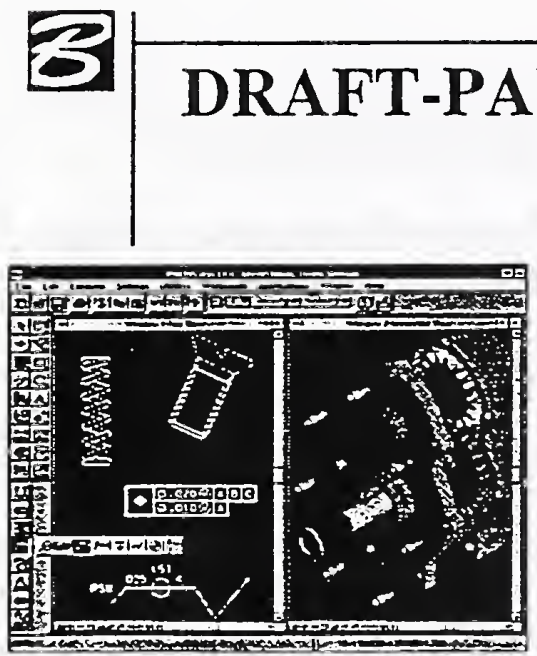

- Mechanical Standard Parts

- Features, fasteners, mechanical elements

- 2D, 3D wireframe, and 3D solid parametrics

- Dimensioning \& Detailing

- Automated GD\&T

- Automatic feature labeling

- Symbols and notes

- ISO, ANSI, JIS, DIN, KS standards

- Bentley distribution world wide 


\section{ESPRIT/MS PowerFold}

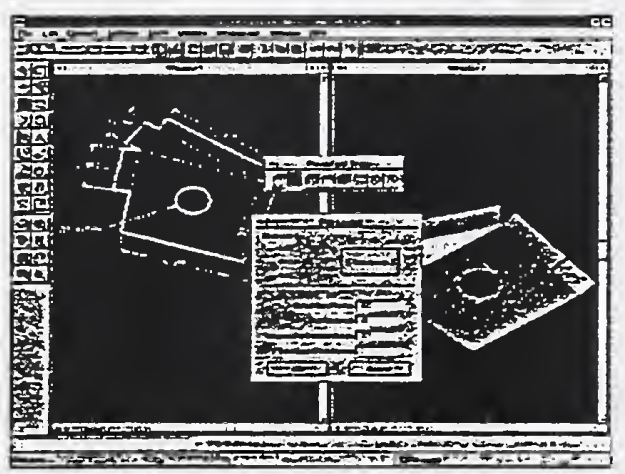

- Sheet metal design

- Forming simulation

- Materials database

- Automated unfolding

- Recognizes weld and bend lines

- Automatic computation of bend allowance

- Bentley distribution worldwide

ESPRIT/MS PowerLink

- MDL application to export MicroStation design database to ESPRIT CAM database

- First step in complete MDL integration

- Shipping now

- DP Technology distribution 


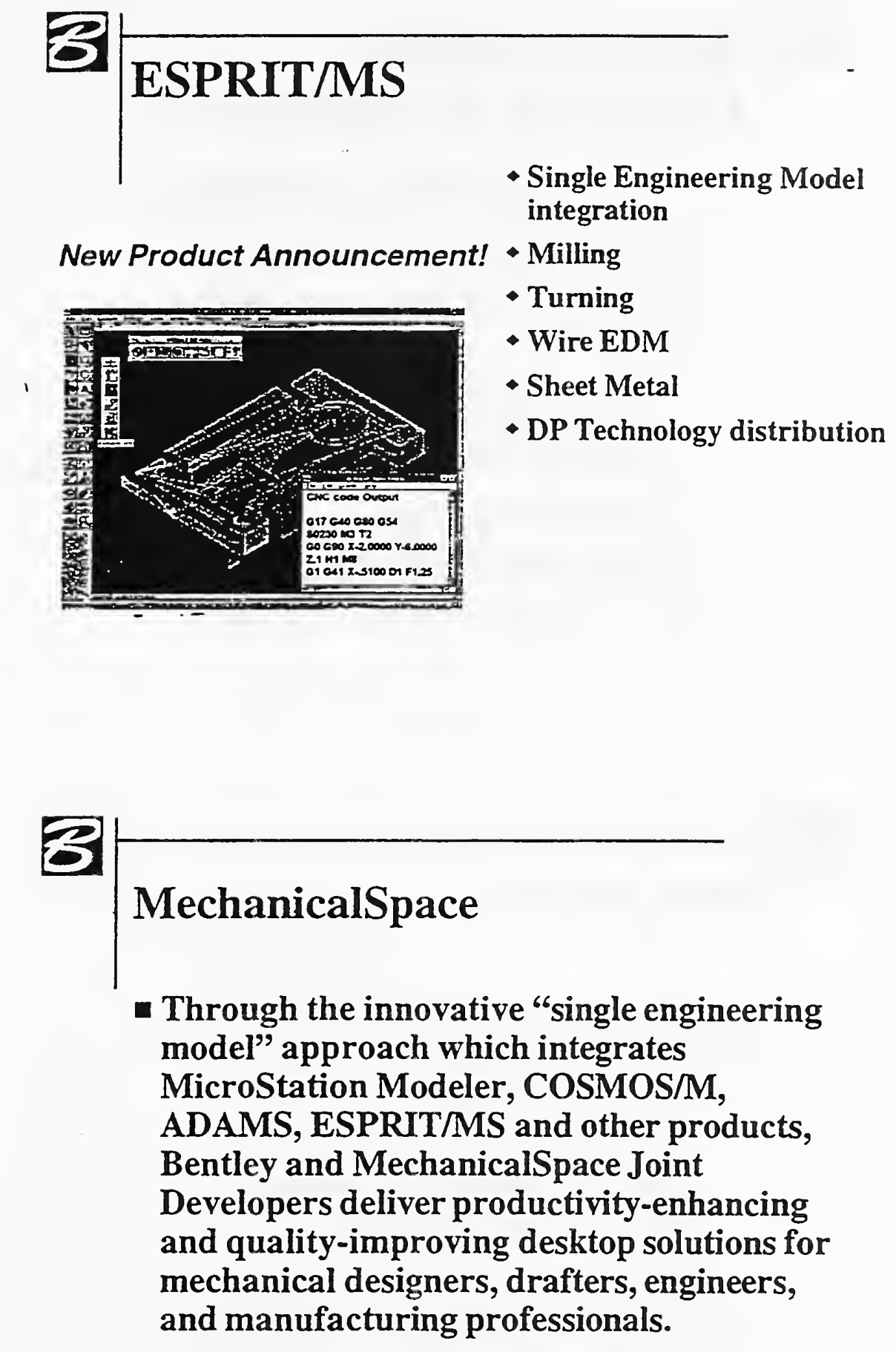


MechanicalSpace

Integration Technology

- MicroStation BASIC, Visual Basic, $\mathrm{C}, \mathrm{C}++, \mathrm{MDL}$

- Over 2,000 functions through API's

- Integrated assemblies, solids, surfaces and wireframes

- Support for standards included (e.g. STEP, IGES, ACIS, OLE)

- Multiple platforms: DOS, Windows, UNIX, MAC

- Single user interface

- Single engineering model

\section{Basics}

- Introduction

- MDL Fundamentals

- MDL Applications

- Performance considerations

- The MDL Runtime Environment

- MDL Development Utilities

- Files Types

- Resource source files

- Dialog Box Manager

- MDL Application Organization 


\section{Basics}

- MDE Workspace

- Tools Menu

- MDE On-line Help

- Design Methodology

- Functional specification

- High-level MDL application design

- Project task list

- Designing a Dialog Box

- Implementing Command Processing

- $*$ Basic Application Architecture

\section{Basics}

- MicroStation Resources

- An Overview of Resources

- Benefits from using resources

- Language Concepts

- Element Descriptors

- Standard C Functions

- Dynamic Link Modules

- Database Manipulation 


\section{MDL \& MechanicalSpace}

- Feature Engine

- Asynchronous Feature Functions

- Feature Linkage Functions

- Miscellaneous

- Solid Modeling Engine Functions

- Entity List Functions

- Solids Creation Functions

- Solid Boolean Operation Functions

- Edge Blending Functions

- Inquiry Functions

\section{MDL \& MechanicalSpace}

m Solid Modeling Engine Functions (continued)

- Entity Type Functions

- Intersection Functions

- Sweeping Functions

- Measurement Functions

- Save and Restore From Disk Files

- Node Id Attachment and Extraction Functions

- Miscellaneous Solid Modeling Functions

- Modeler Engine and Miscellaneous

Functions 


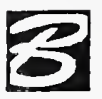

\section{Summary}

- MDL vs. other 3rd party MCAD development environments

- More extensive set of development tools

- Complete access to MicroStation Modeler (and ACIS) core

- COSMOS/M DESIGNER II analysis and ESPRIT/MS manufacturing solutions developed in MDL

\section{Single Engineering Model}

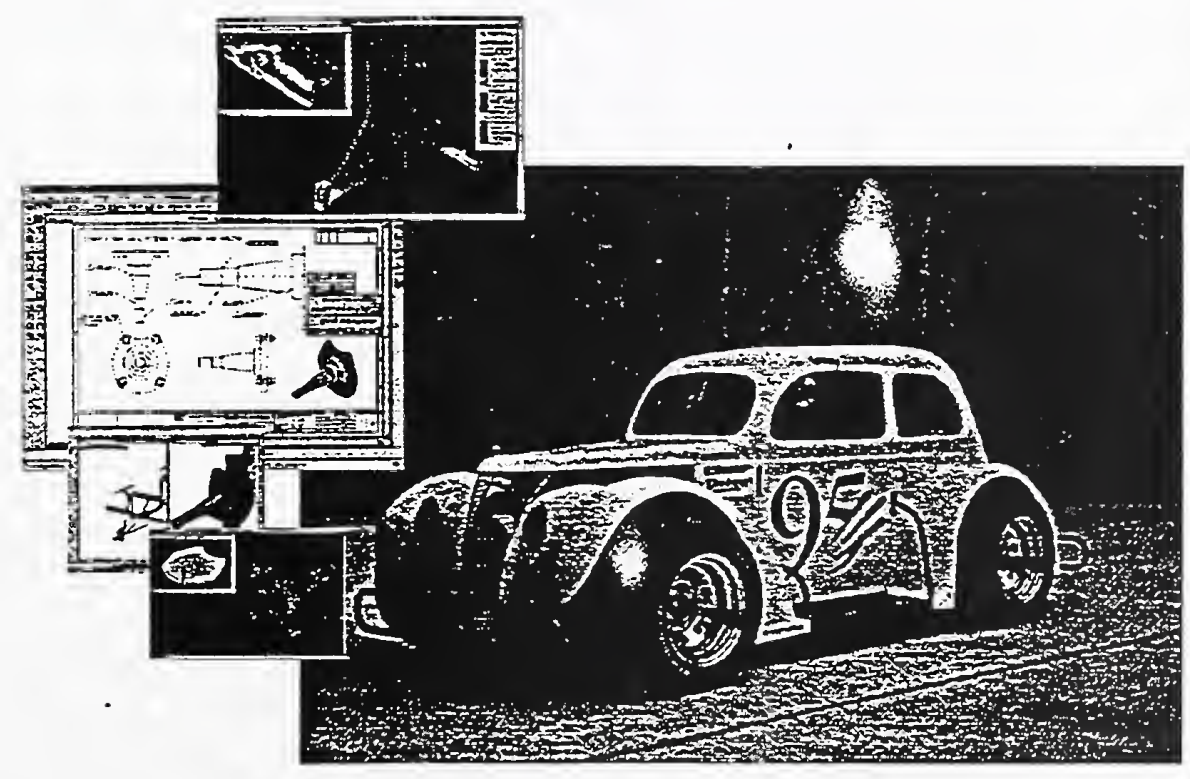





\section{Appendix C5}

Business and Operations Requirements 



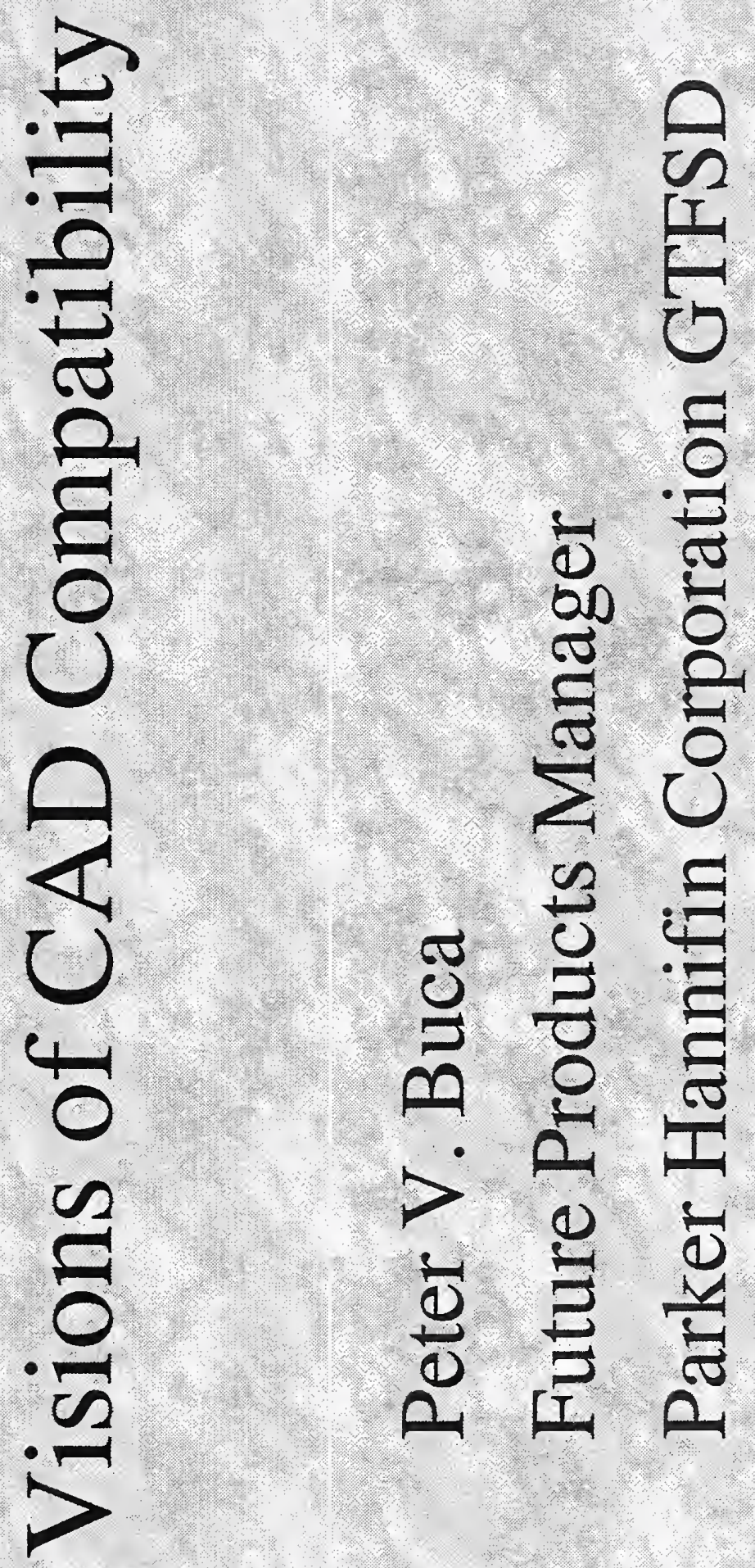




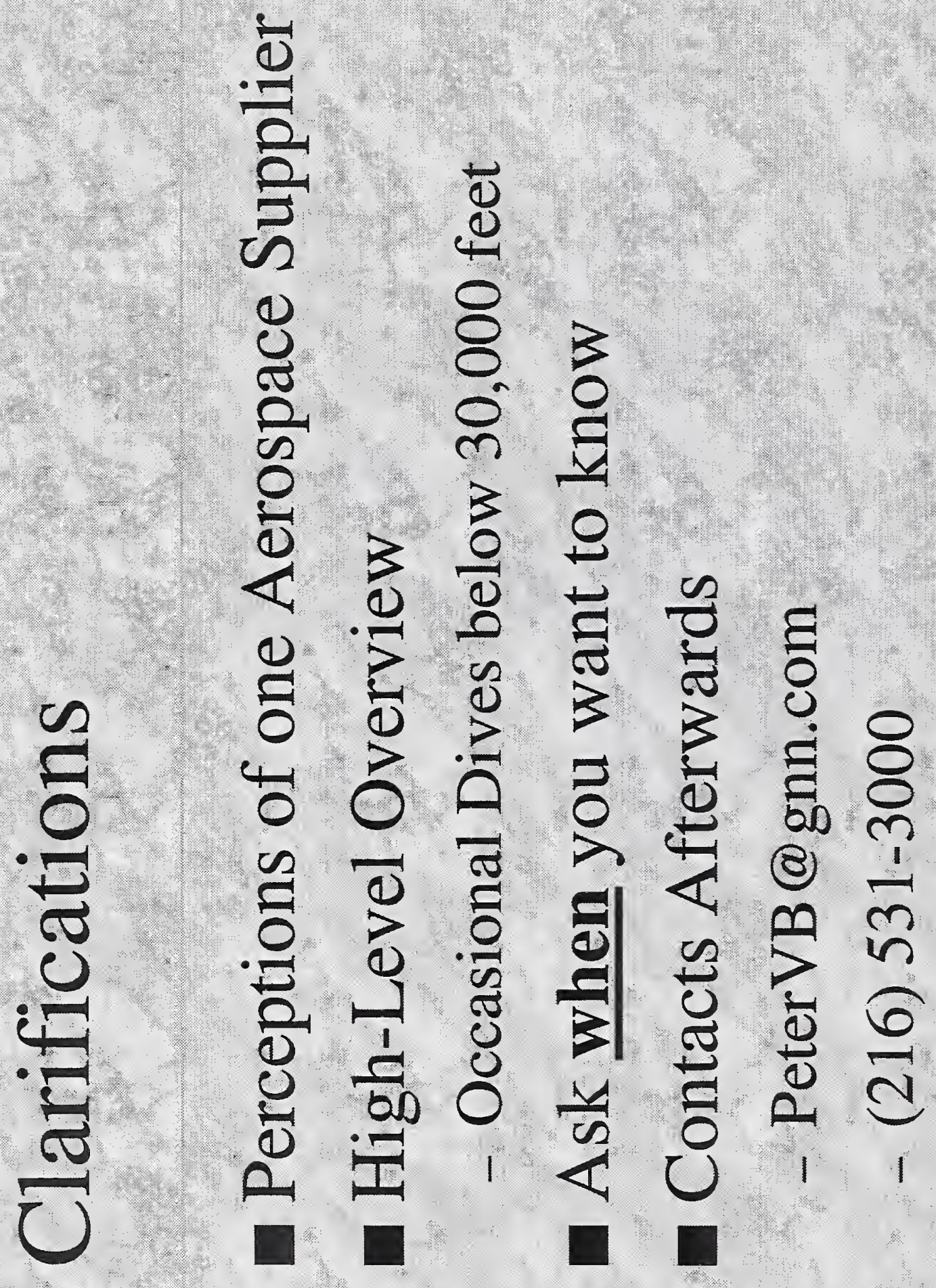




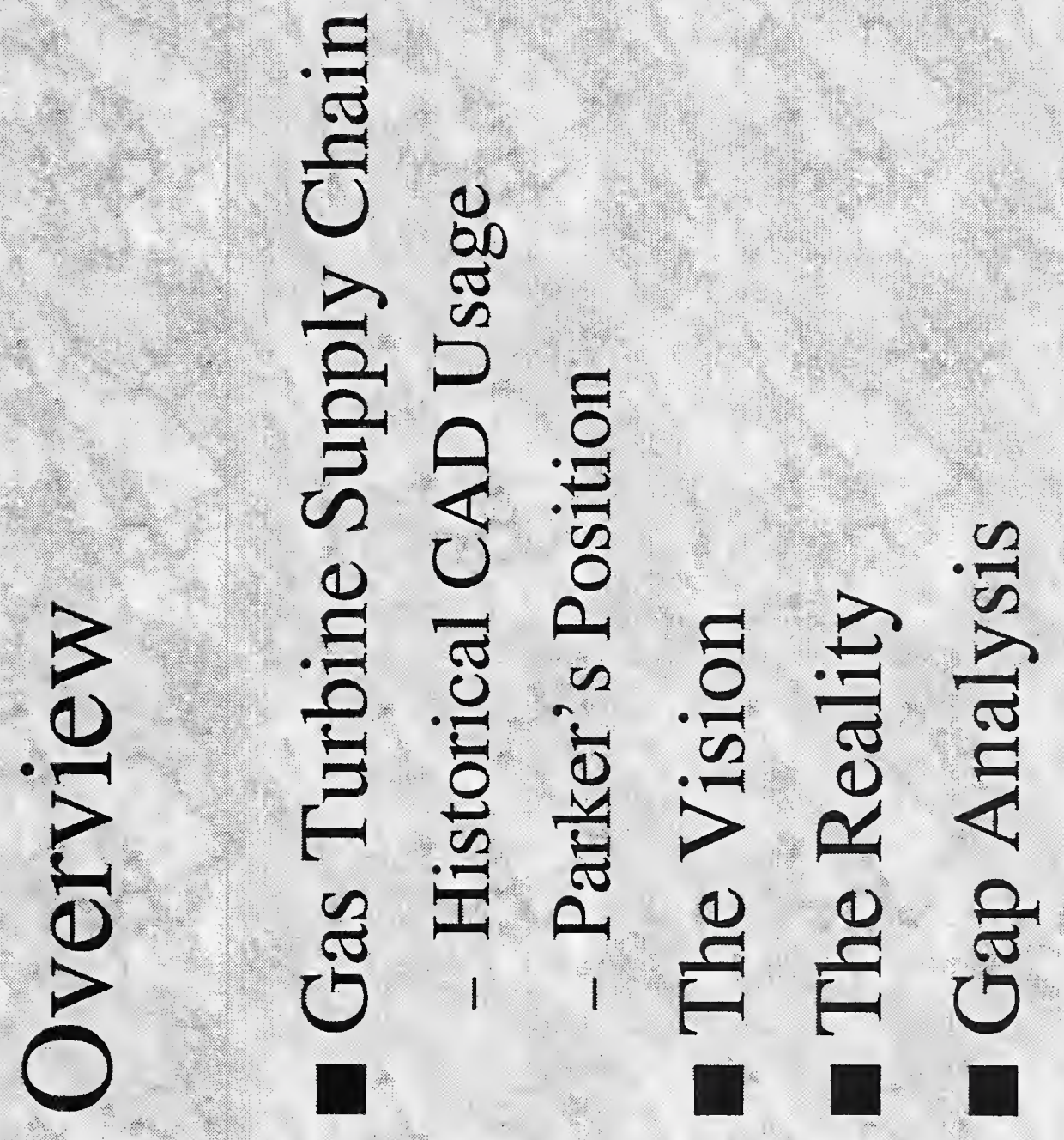




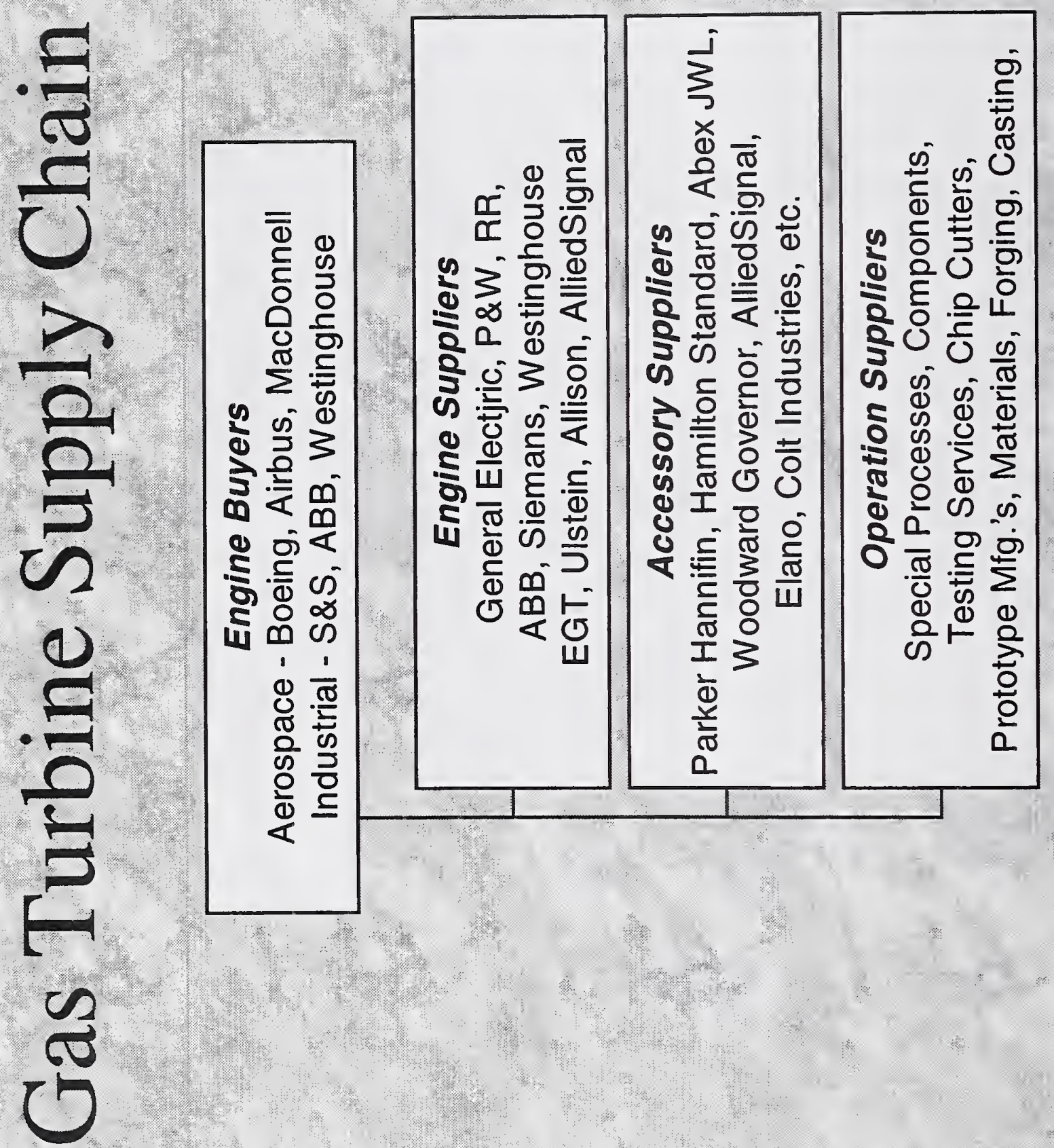




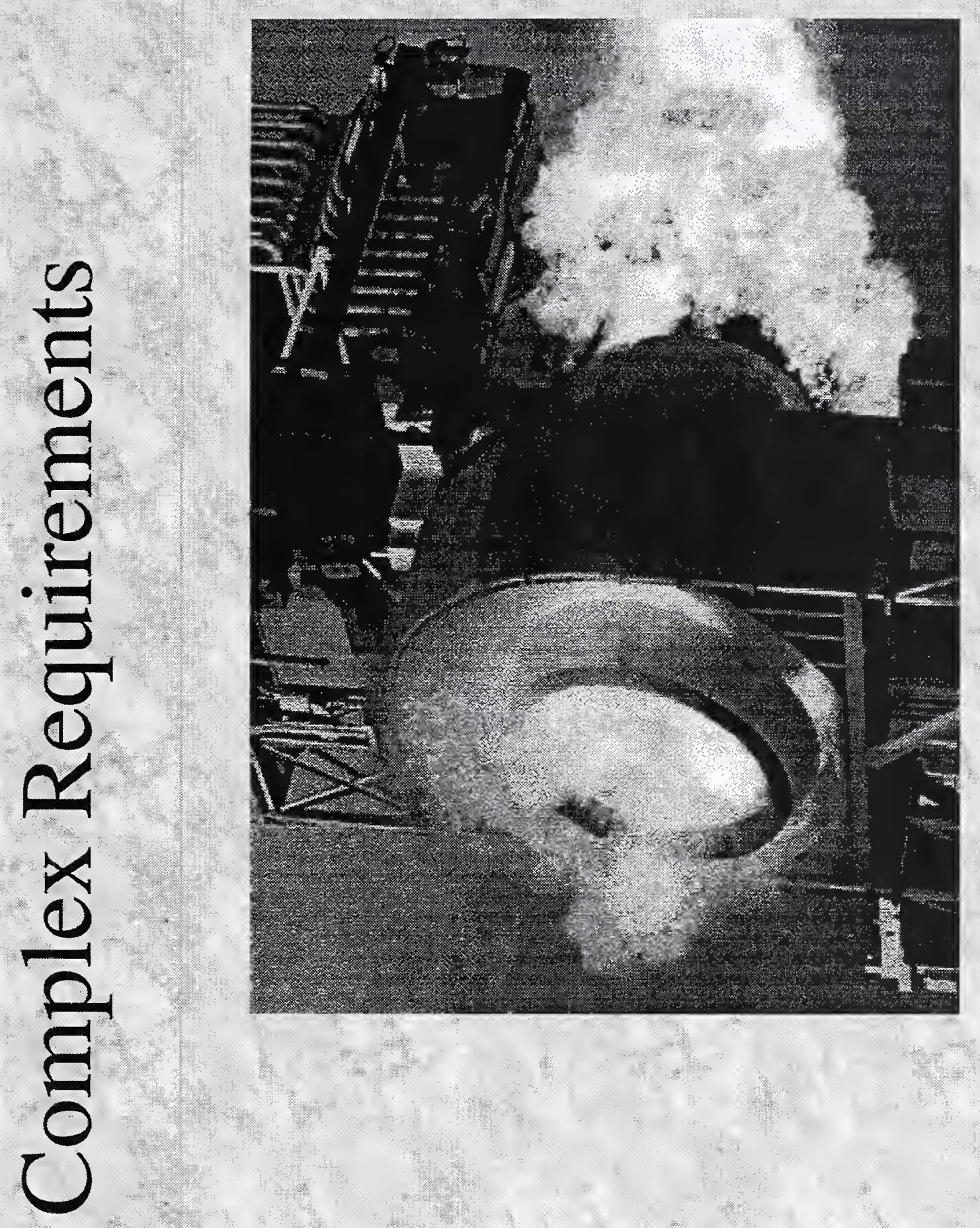




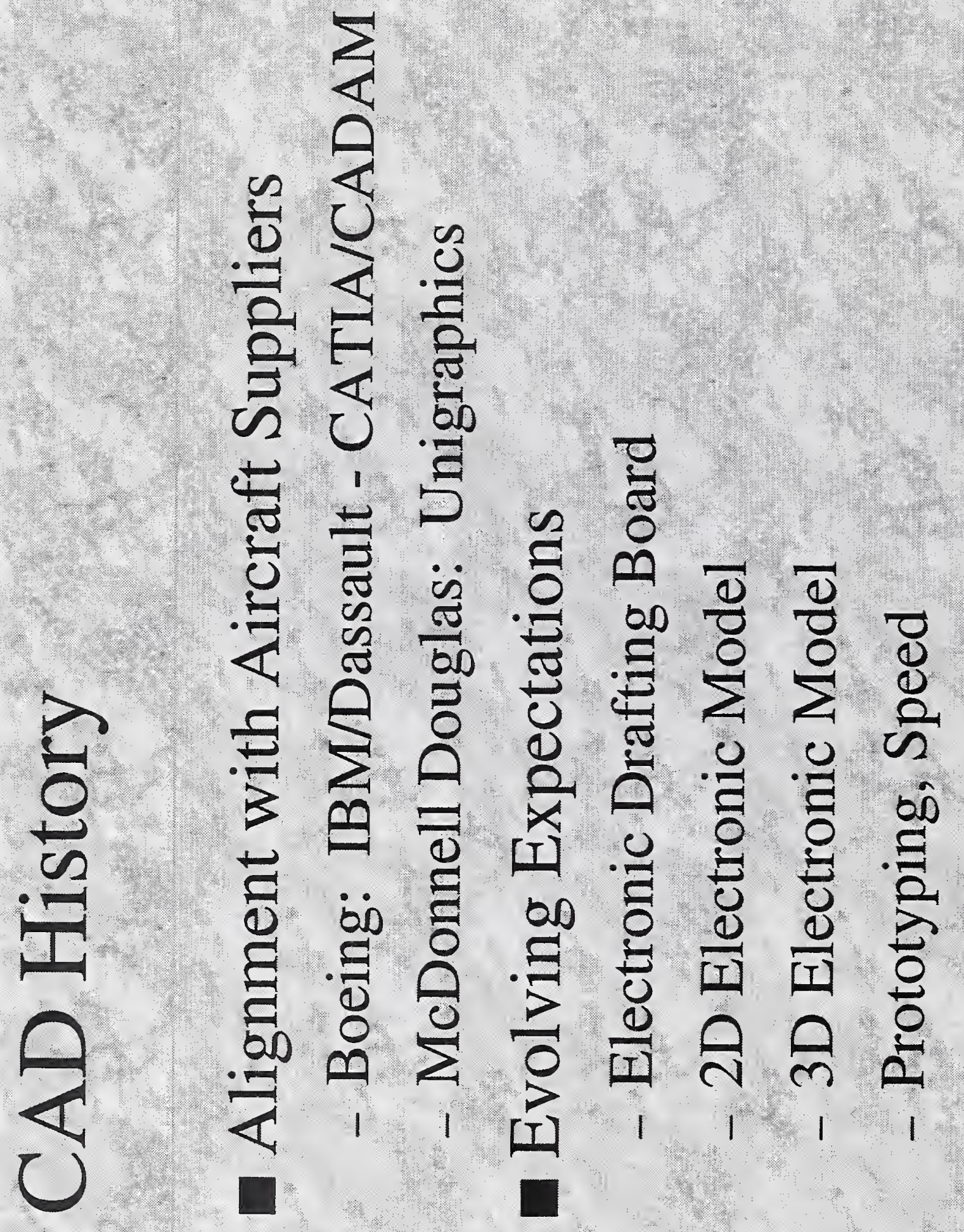



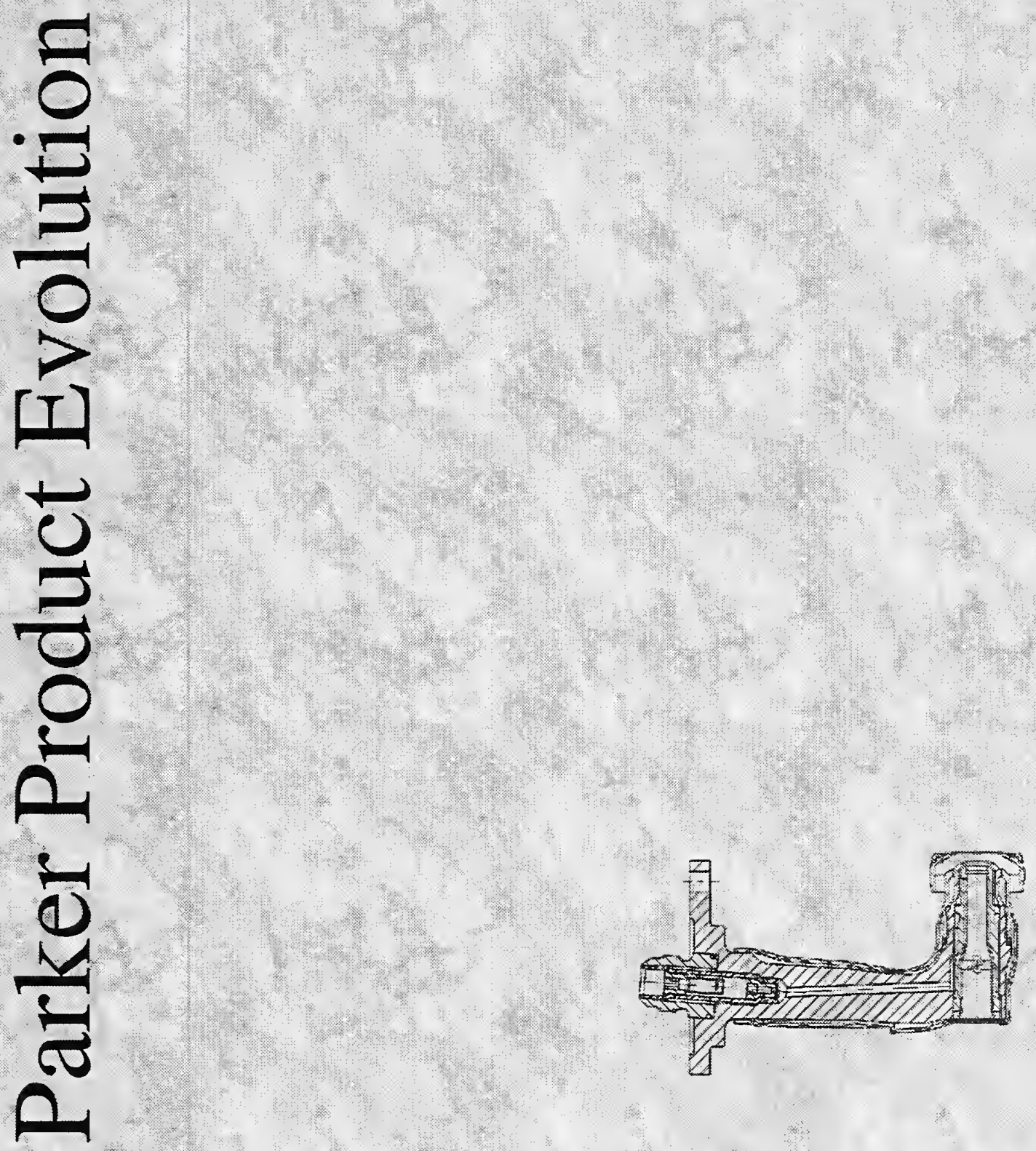

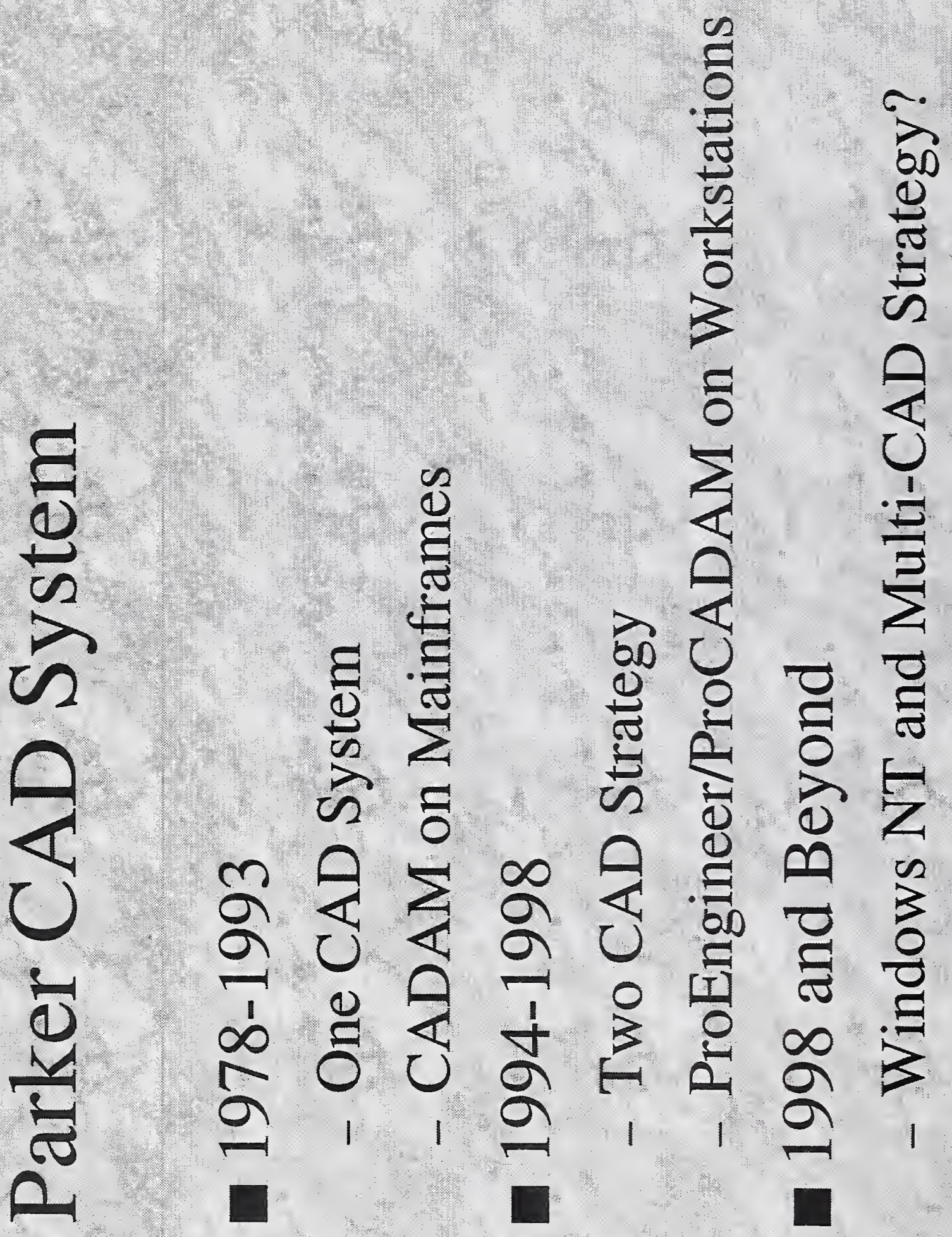


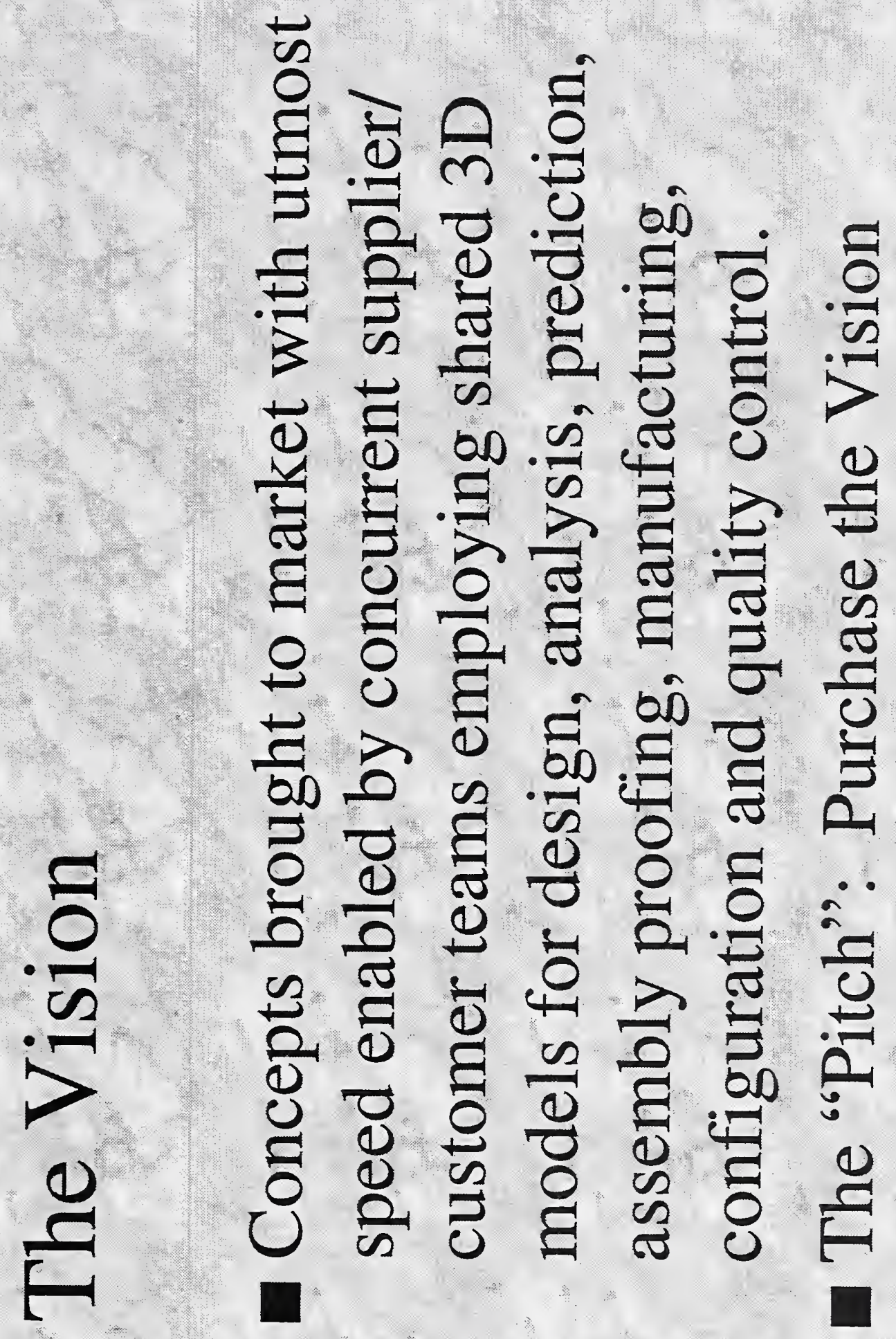




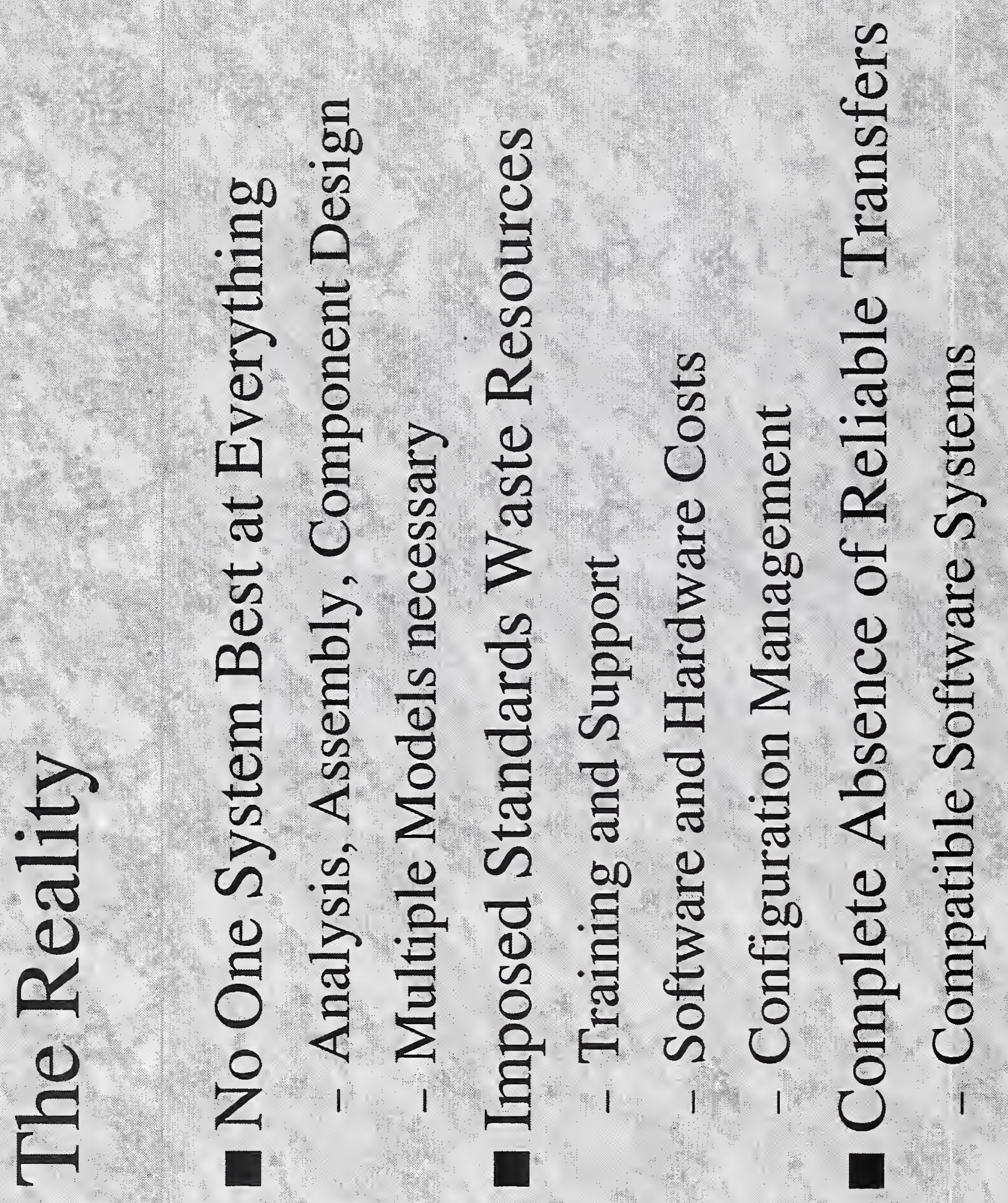




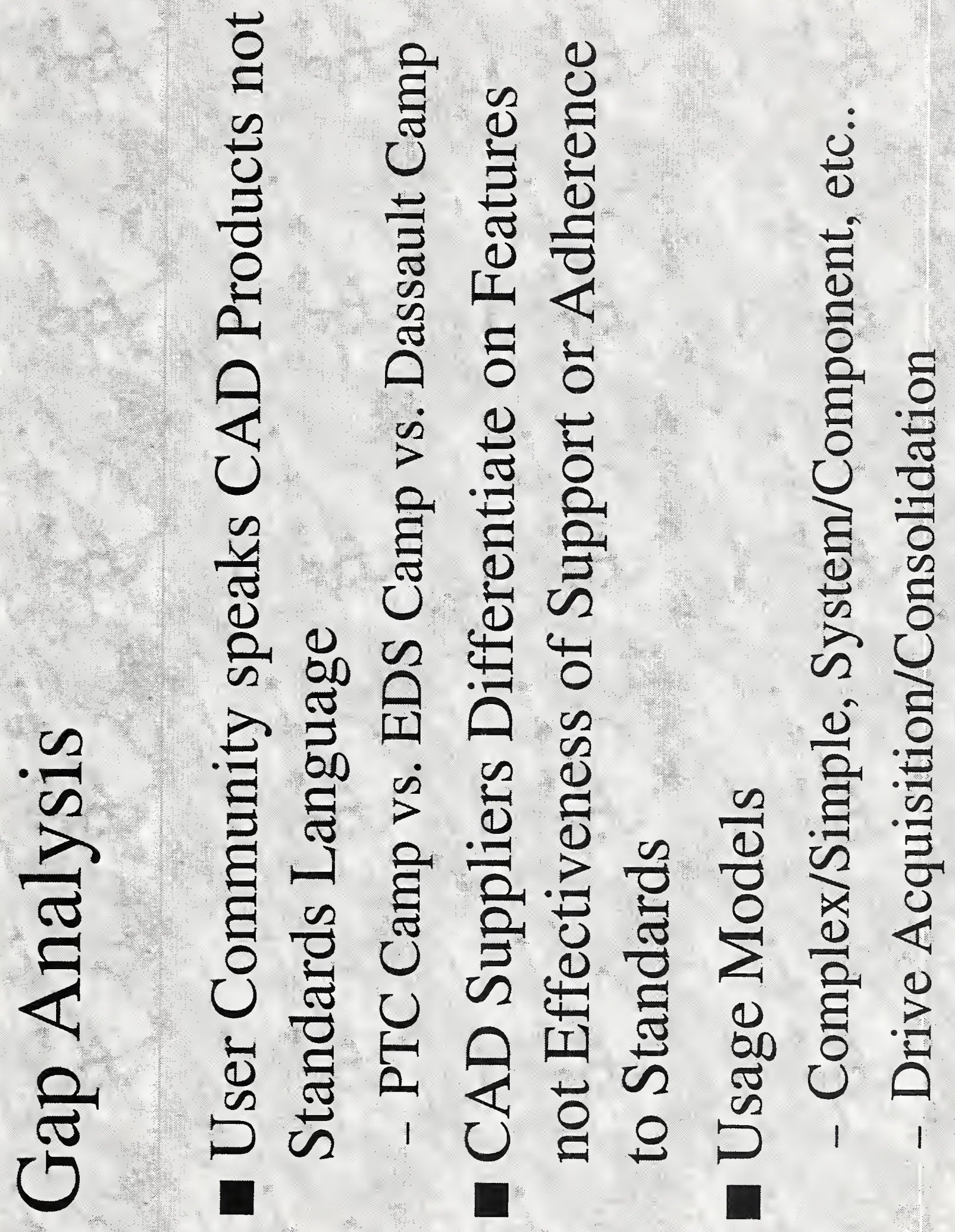



